\title{
STANISŁAW HOZJUSZ W KAPITULE KRAKOWSKIEJ (1540-1550)
}

W bogatym życiorysie Stanisława Hozjusza szczególnie wybija się jego działalność biskupia (w diecezjach chełmińskiej i warmińskiej), podkreślane są jego zasługi dla Soboru Trydenckiego, podziwiany jest jego świątobliwy żywot u schyłku lat w czasie pobytu w Rzymie, mało jednak jest znany okres jego związków z kapitułą krakowską w ostatnim dziesięcioleciu przed przyjęciem sakry biskupiej. Moim zadaniem jest pokazać Hozjusza na tle tejże kapituły, wskazać na krąg osób, z którymi w kapitule był szczególnie związany, na wzajemne współżycie członków kapituły, a to mogło służyć Hozjuszowi jako teren obszernej obserwacji rodzaju i poziomu życia kapłańskiego w przededniu reformy kościelnej, na krakowskie próby obrony czystości wiary, w czym był po części zaangażowany również i sam Hozjusz. Wreszcie pragnę wskazać, jak Hozjusz służył kapitule, spełniając jej polecenia czy zlecenia i jak wykonywał zarząd majątków beneficjalnych oddanych mu w czasie przynależenia do kapituły jako podstawy utrzymania.

Praca niniejsza jest oparta przede wszystkim na źródłach rękopiśmiennych z Archiwum Kurii Metropolitalnej w Krakowie, jak akta biskupów, oraz z Archiwum Kapituły na Wawelu, jak akta posiedzeń kapitulnych, a także na źródłach drukowanych. Jest ona podzielona na sześć rozdziałów stosownie do wyżej podanej tematyki. Każdy z tych rozdziałów obejmuje cały okres pobytu Hozjusza w kapitule krakowskiej, dlatego w opracowaniu niejednokrotnie znajdzie się przypomnienie pewnych wydarzeń już poprzednio na swoim miejscu opisanych. Rozdział siódmy, dający obraz kapituły krakowskiej za czasów Hozjusza, stanowi zakończenie.

I. HOZJUSZ JAKO KANONIK KRAKOWSKI W KREGU PRZYJACIOE I BLISKICH ZNAJOMYCH

Stanisław Hozjusz osiągnął miejsce w kapitule krakowskiej dnia 25 lutego 1540 r., otrzymując od biskupa krakowskiego Piotra Gamrata w 
kurii krakowskiej instytucję kanoniczną na prebendę szczytnicką (znajdującą się w okolicy Proszowic) po rezygnacji Stanisława Słomowskiego, kanonika gnieźnieńskiego ${ }^{1}$. Dwa dni później został na tę prebendę przez kapitułę krakowską instalowany, przychodząc do niej już z tytułem kantora i kanonika warmińskiego ${ }^{2}$. Wchodząc do kapituły krakowskiej Hozjusz znalazł się w środowisku w większej części dobrze mu znanym. Przede wszystkim spotkał się ze znajomymi z dworu biskupa Piotra Tomickiego (1524-1535) z czasu pobytú tam tak przed wyjazdem na studia do Włoch, jak $\mathrm{i}$ w ostatnich latach życia podkanclerzego (1534-1535), kiedy to występował jako prepozyt wieluński i kanonik wiślicki ${ }^{3}$.

Do najbliższych prałatów biskupa Tomickiego należał jego przyjaciel ks. Stanisław Borek ${ }^{4}$, kanonik gnieźnieński i krakowski, kustosz sandomierski, człowiek cieszący się nieskazitelną opinią, następnie dwóch osobistych sekretarzy (secretarii curiae ${ }^{5}$ ): Samuel Maciejowski ${ }^{6}$, kanonik krakowski, kapłan popularny i powszechnie lubiany, oraz Benedykt Izdbieński ${ }^{7}$, od r. 1527 kanonik krakowski, człowiek zdolny, obrotny, niesłychanie pracowity, dlatego mimo pewnych braków swego charakteru umiał się stać niezbędny. Pierwszy $\mathrm{z}$ nich $\mathrm{w}$ chwili przyjęcia Hozjusza do kapituły krakowskiej miał nominację na biskupa chełmskiego ${ }^{8}$ i niedługo potem odszedł z kapituły, choć jeszcze z Karolem Antonim de Monte Cinere ${ }^{9}$ asystował przy jego instytucji. Tenże Samuel, jako podkanclerzy państwa polskiego, chociaż kolejno obejmował biskupstwa w Cheł-

1 Acta Episcopalia w Archiwum Kurii Metropolitalnej w Kraikowie (Ep. Crac.), tom 22, k. 15; Stanislai Hosii S.R.E. cardinalis epistolae, orationes, legationes, wyd. F. Hipler i W. Zakrzewski. Tom I (1525-1550), Kraków 1879 (Hos. eplae), nr 64, s. 88. W liście do Dantyszka pisanym dnia 10 III 1540 Hozjusz wyznaje, że otrzymanie kanonii krakowskiej zawdzięczał Samuelowi Maciejowskiemu, wówczas biskupowi chełmskiemu: Chelmensis episcopi beneficio Cracoviensis canonicatu sum honoratus.

2 Acta Capitularia Ecclesiae Cracoviensis (Cap. Crac.), tom 3, k. 247'; Hos. eplae I, appenndix (app.) 4, s. 410 (5 VII 1528): Possessio canonicatus Varmiensis data Stanislao Hosio.

3 Ep. Crac. 13, kk. 418, 418'-419. Już biskup krakowski Jan Konarski (15031524) zwrócił swą uwagę na Hozjusza, który po skończeniu studiów w Akademii Krakowskiej zajmował się uczeniem młodzieży, a biskup P. Tomicki (1524-1535) zlecił mu kształcenie na swoim dworze młodzieńców z rodów spokrewnionych $\mathrm{z}$ biskupem. Zob. list biskupa Tomickiego do biskupa przemyskiego Jana Chojeńskiego z dnia 18 IX 1534 (Hos. eplae, I app. 1, s. 409-410).

${ }_{4}^{4}$ H. Barycz, W. Pociecha, Borek Stanistaw (1474-1556), [w:] Polski Słownik Biograiczny (PSB) 2, s. 320-322.

5 Ep. Crac. 11, k. 241'; 13, k. 451'.

6 W. Dworzaczek, Maciejowski Samuel, h. Ciolek (1499-1550), [w:] PSB 19, s. $64-69$.

${ }^{7}$ Ep. Crac. 13, 560'-561; 15, k. 157, 166; Cap. Crac. 4, k. 59'; Izdbieński Benedykt, h. Poraj (1488-1553), [w:] PSB 10, s. 194-195.

${ }_{8}$ Mianowany dnia $17 \times 1539$ - por. Hierarchia catholica medii et recentioris devi, opr. Eubel, van Culik, Gauchat;' Rizler i Sefrin. Monasterii Patavii 19131952 (HE), tom III, 180.

9 D. Quirini-Popławska, Marchesini Carlo Antonio, PSB 19, s. 530. 
mie (1539-1541) i w Płocku (1541-1546), nie mógł opuścić Krakowa i stąd jego bliskie kontakty z Hozjuszem nie zostały zerwane. Czwartym ulubionym prałatem biskupa Tomickiego był Jan Wilamowski ${ }^{10}$. Został on $17 \times 1539$ mianowany biskupem kamienieckim ${ }^{11}$, ale $\mathrm{w}$ dalszym ciągu pozostawał w Krakowie jako kantor kapituły ${ }^{12}$. Po powrocie z Rzymu ${ }^{13}$ przyjął sakrę biskupią i w czasie przygotowań do wyjazdu na Węgry do królowej Izabeli, córki Zygmunta Starego, niespodziewanie zmarł 6 X 1540 r. ${ }^{14}$ podczas nieobecności Hozjusza w Krakowie. Piątym prałatem Tomickiego był Jerzy Myszkowski z Przeciszowa, z możnej rodziny na terenie księstwa zatorskiego, ongiś spokrewnionej z tamtejszymi książętami, archidiakon katedralny, który w czasie pobytu Hozjusza na dworze biskupim pełnił obowiązki kanclerza ${ }^{15}$.

Obok powyższych spotkał się Hozjusz na dworze Tomickiego z prałatami konsystorskimi. Jeden $\mathrm{z}$ nich, Mikołaj Bedleński ${ }^{16}$, był wikariuszem generalnym (in spiritualibus), a drugi, Tomasz Rożnowski ${ }^{17}$, oficjałem generalnym. Hozjusz, zostawszy kanonikiem krakowskim, w kapitularzu wawelskim już ich nie zobaczył. Pierwszy z nich, najstarszy w kapitule, instytuowany jeszcze przez Fryderyka Jagiellończyka, był już dogorywający (zm. 17 IV 1540), lecz przed śmiercią wyświadczył Hozjuszowi tę przysługę, że przyjął do swego domu (Kanonicza 15) Benedykta Izdbieńskiego i dzięki temu Hozjusz jako nowy instalowany kanonik krakowski mógł otrzymać dom opróżniony przez Izdbieńskiego (Kanonicza 8). Drugi, to jest Tomasz Rożnowski, umarł 21 I 1540 r., tuż przed przyjściem Hozjusza do kapituły.

Prócz prałatów przebywali na dworze P. Tomickiego domownicy ( $f a-$ miliares) biskupa. Liczba ich była spora, jak przystało na kurię możnego pana. Pięciu $\mathrm{z}$ nich, którzy potem zostali kanonikami krạkowskimi, z pewnością było zaprzyjaźnionych z Hozjuszem. Byli to: Stanisław Górski ${ }^{18}$, kanonik płocki, który zaczął zbierać materiały nazwane później

10 Cap. Crac. 3, k. 243'; „Wilamowski Jan z kanonika gnieźnieńskiego, poznańskiego, kantora krakowskiego biskup kamieniecki, h. Szaszor albo Orla (um. 1540)“, - J. Korytkowski, Prałaci $i$ kanonicy katedry gnieźnieńskiej (Korytk. Prałaci), t. IV, Gniezno 1882, s. 291-294; Wypisy źródłowe do dziejów Wawelu 1516-1525, wydał Bolesław Przybyszewski (Wp. źródł. III), nr 69, przypis 3, s. 40-41.

$11 \mathrm{HE}$ III, 148.

12 J. Wilamowski został przyjęty na kantorię krakowską 27 XI 1535. Cap. Crac. 3, k. $132^{\prime}-133^{\prime}$.

13 Cap. Crac. 3, k. 243'.

14 Ep. Crac. 18, k. 359; Cap. Crac. 3, k. 270-271'.

15 Ep. Crac. 11, k. 193' (r. 1528); 15, k. 157; H. Kowalska, Myszkowski Jerzy, h. Jastrzębiec (ok. 1480-1543), [w:] PSB 22, s. 372-373.

16 J. Krzemieniecki, Bedleński Mikotaj z Bedlna (u. 1540), PSB 1, s. 395; Wypisy źódłowe do dziejów Wawelu 1501-1515, wydał i opracował Bolesław Przybyszewski, Kraków 1965 (Wp źródł. II), nr 73, s. 68.

${ }_{17}$ Tomasz Rożnowski, h. Nowina (um. 1540) - zob. Wp źródł. II, nr 113, s. 9899.

18 Ep. Crac. 15, k. 157; W. Urban, Górski Stanisław, h. Bogoria (ok. 1497-1572), [w:] PSB 8, s. 452-454. 
Acta Tomiciana. Górski przylgnął całym sercem do Hozjusza i był mu zawsze oddany. Skarbnikiem kurii Tomickiego był Piotr Porębski ${ }^{19}$, prepozyt oświęcimski, kapłan gorliwy, niesłychanie pracowity i dobry gospodarz oraz prawnik. Lubiany przez biskupa Tomickiego, jak i jego następców, Wojciech Kijowski, dziekan sądecki, zarządzał sprawami finansowymi ${ }^{20}$. Ze zwykłych notariuszy kurii biskupiej weszli w szeregi bliskich dworzan Tomickiego (podobnie jak Stanisław Górski) Filip Padnièwski ${ }^{21}$, późniejszy biskup krakowski (1560-1572), i Andrzej Przecławski, który był w latach 1560-1563 nawet pierwszym wikariuszem generalnym biskupa Padniewskiego, jednakże młody Filip Padniewski oddalił się wewnętrznie od Hozjusza, podczas gdy Przecławski stale pozostawał z nim blisko.

Po śmierci P. Tomickiego kamienica „Ciołkonis” (Kanonicza 17) w Krakowie przestała być ogniskiem kultury renesansowej i życia politycznego ${ }^{23}$. Następny biskup krakowski Jan Latalski ${ }^{24}$ zastrzegł sobie ten dom, lecz niedługo przeniósł się na arcybiskupstwo gnieźnieńskie. Z następcą jego Janem Chojeńskim ${ }^{25}$, który 16 II 1537 został kanclerzem koronnym i wkrótce potem (4 VII) biskupem krakowskim, zaraz zaprzyjaźnili się Samuel Maciejowski, Jan Wilamowski oraz Hozjusz. Chojeński otworzył wspaniały dwór renesansowy przy ulicy Poselskiej 12. Znalazł się na nim także Hozjusz jako młody prepozyt wieluński oraz scholastyk skalbmierski ${ }^{26}$, który dzięki protekcji kanclerza otrzymał w r. 1538 stanowisko sekretarza królewskiego. Pobyt na dworze Chojeńskiego, niestety wkrótce zgasłego, był dla Hozjusza bardzo pouczający: poznał biskupa o najwyższej kulturze humanistycznej, a zarazem gorąco przywiązanego do wiary katolickiej, wbrew powtarzającemu się zjawisku, że biskup humanista to człowiek niezdecydowany w poglądach na sposób naprawy Kościoła. Na dworze Chojeńskiego spotkał Hozjusz przy-

19 Piotr Porębski był prezenitowany na prepozyturę oświęcimską 7 IV 1533 (Ep. Crac. 3, k. 449; 13, k. 233', 257). Porębski umarł jako scholastyk krakowski (15601569) (Cap. Crac. 5, k. 405'-406; 6, k. 141').

20 Ep. Crac. 15, 132'; Cap. Crac. 6, k. 69'.

21 L. Hajdukiewicz, H. Kowalska, Padniewski Filip, h. Nowinx (um. 1572), [w:] PSB 21, s. $1-7$.

22 Ep. Crac. 11, 209'.

23 S. Łempicki, Biskupi polskiego renesansu jako opiekunowie kultury, „Przegląd Powszechny" 200 (1933) s. 485.

${ }^{24}$ I. Sułkowska-Kurasiowa, Latalski Jan, h. Prawdzic (1463-1540), PSB 16, s. $562-563$.

${ }_{25}$ W. Pociecha, Chojeński Jan, h. Abdank (1486-1538), PSB 3, s. 396-399.

${ }_{26}$ Administratorialia Cracoviensia (Adm. Crac.) II, s. 9 i 69; Jan Chojeński, wówczas biskup płocki, w liście pisanym z Wilna 23 III 1536 do J. Latalskịiego, biskupa krakowskiego, podaje, że od dawna cenił Hozjusza, jeszcze wtedy, gdy ten pełnił zadanie pedagoga nepotów biskupa krakowskiego Jana Konarskiego, a po śmierci tegoż biskupa - dzięki jego poleceniu - otoczył go swą łaskawością następca Konarskiego Piotr Tomicki. Gdy znów umarł Tomicki, wtedy bp Chojeński wziął go na swój dwór, już nie do pisania listów, jak to było za poprzednich biskupów (Konarskiego i Tomickiego), ale jako uczestnika rozmów prowadzonych w 
Szłego kolegę z kapituły Bartłomieja Niszczyckiego ${ }^{27}$, kanclerza płockiego, jak również Mikołaja Dzierzgowskiego ${ }^{28}$, przyszłego prymasa Polski, który wszakże nigdy nie należał do kapituły krakowskiej.

Po rychłej śmierci biskupa Chojeńskiego (11 III 1538) Hozjusz związał się z następnym ordynariuszem krakowskim Piotrem Gamratem $\left(1538-1545^{29}\right)$. Na Gamratowym dworze Hozjusz poznał szlachetnego, o wysokiej kulturze człowieka, jakim był opat mogilski Erazm Ciołek ${ }^{30}$, przyjęty $8 \times 1536$ r. jako canonicus natus do kapituły krakowskiej ${ }^{31}$. Gamrat dał swemu ulubieńcowi dochody ze wsi biskupiej Posądzy ${ }^{32}$, które Ciołek przyjął z wdzięcznością, jako wyraz uznania dla swej osoby, choć bogaty opat z pewnością tej gratyfikacji nie potrzebowal ${ }^{33}$. Erazm Ciołek należał do siedmiu najbardziej stałych w wierze kanoników za czasów Gamrata; obok samego opata, zaliczano do nich: Stanisława Borka, Bartłomieja Gądkowskiego ${ }^{34}$, Stanisława Hozjusza, Marcina Kromera ${ }^{35}$, Jakuba z Kleparza ${ }^{36}$ i Zygmunta ze Stężycy ${ }^{37}$. Po śmierci Stanisława Małachowskiego, dominikanina i profesora teologii, biskupa laodycejskiego, sufragana krakowskiego, Gamrat dał dnia 26 VIII 1544 r. prowizję na jego następcę na stanowisku biskupa pomocniczego Erazmowi Ciołkowi ${ }^{38}$. Ponieważ odtąd sufragani mieli być rzeczywistymi kanonikami katedralnymi, dlatego Ciołek trzy dni później został przyjęty na

towarzystwie ludzi uczonych, których w Płocku nie miał wielu (Hos. eplae I, app. 2 , s. $409-410)$.

27 Ep. Crac. 23, k. 7; PSB 23, s. 134. Bartłomiej Niszczycki, kanonik (1533) i kanclerz płocki, kanonik krakowski (1540) i gnieźnieński, zmarły w r. 1557, jest wspomniany przy biogramie jego ojca Andrzeja.

28 W. Pociecha, Arcybiskup gnieźnieński Mikołaj Dzierzgowski, prymas Polski (1490-1559), „Nasza Przeszłośćc (1947) s. 37-102.

${ }^{29}$ K. Hartleb, Gamrat Piotr, h. Sulima (1467-1545), [w:] PSB 7, s. 264-266; W. Pociecha, Królowa Bona (1494-1557). Czasy i ludzie Odrodzenia t. II, Poznań 1949, s. 77-78, 134, 589; t. III, Poznań 1958, s. 192; t. IV, Poznań 1958, s. 223. Piotr Gamrat, jeszcze jako biskup płocki i electus Cracoviensis, piszac dnia 20 VII 1538 z P.ułtuska do Dantyszka, nazywa Hozjusza sobie oddanym i oświadcza, że jest on dla niego jakby brat najdroższy (sibi addicto et tanquam fratre carissimo) oraz chwali go za posiadanie nadzwyczajnej wiedzy i za łagodność obyczajów (singularis doctrina et mores suavissimi) - por. Hos. eplae I, app. s. 410.

${ }^{30}$ W. Pociecha, Ciołek Erazm (ur. ok. 1482-1546), [w:] PSB 4, s. 81-82.

31 Ep. Crac. $18, k .136^{\prime}$; Cap. Crac. 3, k. 158'.

32 Dnia 8 X 1541. Cap. Crac. 3, k. 322.

${ }^{33} \mathrm{~W}$ akcie nadanie Posądzy Gamrat zamieścił taką pochwałę Erazma: „qua fide et constantia, quo more et affectu, quibus denique officiis ab annis iam compluribus colamur a reverendo domino patre divina vocatione abbate Mogilensi ecclesiaeque mostrae Cracoviensis canonico primo nato: qui etiam suopte naturae instituto ac probatissimis et comitate plurima conspicuis moribus suis, vel hoc consecutus, ut nedum serenissimis principibus nostris, verum etiam cunctis Regni huius ordinibus apprime sit gratus et acceptus."

${ }_{34}$ J. Nowacki, Gadkowski Bartłomiej, (um. 1554), [w:] PSB 7, s. 338.

35 H. Barycz, Kromer Marcin, [w:] PSB 15, s. 319-325. 357.

36 L. Hajdukiewicz, Jakub z Kleparza (ok. 1484-1553), [w:] PSB 10, s. 356-

${ }^{37}$ Zygmunt ze Stężycy, profesor prawa i rektor uniwersytetu, kanonik krakowski (Wp źródł. III, nr 266, s. 154).

${ }^{38}$ Cap. Crac. 4, k. 27-30. 
prebendę bieżanowską. Kapituła uczyniła to niezbyt chętnie, bo nowo wybrany sufragan był plebejuszem i do tego bez doktoratu, a stopień naukowy doktora był dla plebejuszy koniecznym warunkiem dopuszczenia do grona członków kapituły.

W czasie swej instalacji na prebendę szczytnicką Hozjụsz spotkał się z Karolem Antonim Marchesinim, ulubieńcem Bony i dawnym sekretarzem biskupa płockiego Erazma Ciołka ${ }^{39}$, a przez to miłym Gamratowi, który postanowił wprowadzić go do kapituły krakowskiej. Umarł właśnie sędziwy scholastyk Mikołaj Bedleński (17 IV 1540), a już 20 IV Gamrat udzielił prowizji na scholasterię krakowską Karolowi Antoniemu ${ }^{40}$, który jednak nie kwapił się do jej objęcia, bo wiedział, że Bedleński uczynił za swego życia koadiutorem prałatury Jana Naropińskiego ${ }^{41}$ i on miał pierwszeństwo do jej objęcia. Naropiński był znany jako człowiek gwałtowny i nie przebierający w środkach, gdy chodziło o zdobycie nowego beneficjum kościelnego. Marchesini nie chciał się Naropińskiemu narażać i czym prędzej zamienił się prałaturą scholastyka krakowskiego z Andrzejem Czarnkowskim ${ }^{42}$, który jako potomek jednego z najmożniejszych rodów wielkopolskich, mający wielkie znaczenie na królewskim dworze, mógł prostesty Jana Naropińskiego zlekceważyć. Czarnkowski dał Marchesiniemu tytułem zamiany kanonię krakowską i parafię w Niegardowie. Czarnkowski już 22 IV był instytuowany na scholasterię krakowską ${ }^{43}$, a następnie przyjęty przez kapitułę ${ }^{44}$, która-była uradowana takim obrotem sprawy, bo nie chciała widzieć Naropińskiego na stanowisku kierownika szkoły zamkowej. Nie przewidziała tylko, ile kłopotów przyniesie jej sprawa obsady scholasterii. Już w październiku $1540 \mathrm{r}$. występują wzmianki o śmierci Karola Antoniego. Wakuje po nim Pobiednik ${ }^{45}$, a egzekutor jego testamentu Bartłomiej Gądkowski ${ }^{46}$, został po nim instytuowany na Koniuszę ${ }^{47}$. W tym czasie, kiedy kapituła była zajęta sprawą scholasterii, Hozjusz starał się o uzyskanie jednego z domów kapitulnych na mieszkanie. Pomógł mu w tym serdeczny niegdyś kolega z dworu Piotra Tomickiego Benedykt Izdbieński, który uprosił Mikołaja Bedleńskiego, by zrezygnował ze swego domu na jego rzecz. Bedleński, który wybudował budynek szkoły na zamku i dwie kamienice dla kano81.

39 S. Łempicki, Ciołek Erazm (biskup płocki i dyplomata), [w:] PSB 4, ${ }_{8}$. 78-

40 Ep. Crac. 18, k. 306'-307.

$41 \mathrm{H}$. Kowalska, Naropiński Jan, h. Belina (ok. 1467-1543), [w:] PSB 22, s. $549-550$.

42 J. Nowacki, Czarnkowski Andrzej, h. Nałęcz (1507-1562), [w:] PSB 4, s. 216-217; W. Pociecha, Królowa Boña, II, s. 385, IV, s. 282.

43 Ep. Crac. 18, k. 310.

44 Cap. Crac. 3, k. 252-252'.

45 Ep. Crac. 18, k. 257.

46 Ep. Crac. 19, k. 9.

47 Ep. Crac. 18, k. 263, 402'; 22, k. 48. 
ników: „Zerwikaptur” naprzeciw kościoła św. Andrzeja i dom przy ulicy Kanoniczej $.15^{48}$, gdzie właśnie dogorywał, pozwolił Benedyktowi wprowadzić się do siebie, by do zwolnionej przez Izdbieńskiego kamienicy mógł wprowadzić się Hozjusz. Był to dom usytuowany retro Collegium Canonistarum, czyli dzisiaj kamienica przy ulicy Kanoniczej $8{ }^{49}$. Tu znalazł doktor Hozjusz siedzibę na najbliższe trzy lata (1540-1543).

Po odejściu Mikołaja Bedleńskiego, który był wikariuszem generalnym aż pięciu biskupów, stanowisko wikarego chwilowo piastował Paweł Krassowski ${ }^{50}$ (17 IV -7 V 1540), a nominację na zastępcę zasłużonego Mikołaja otrzymał Benedykt Izdbieński. W ten sposób kamienica przy ulicy Kanoniczej 15 dalej była konsystorzem wikariusza aż do końca życia Gamrata. W 1546 r. Izdbieński jako biskup kamieniecki i elekt poznański wprowadził do swej kamienicy zaufanego przyjaciela, Bartłomieja Gądkowskiego, zastrzegając sobie w tym domu prawo hospitii, tj. gościny, ilekroć przyjedzie z Poznania do Krakowa ${ }^{51}$. Gądkowski odznaczał się pracowitością, nieskazitelnością obyczajów, przykładem kapłańskiego życia i przywiązaniem do Kościoła. Kapituła miała do niego zaufanie, tak samo i biskup Gamrat, który uczynił go swym kanclerzem (1540-1545), jako następcę Jana Wilamowskiego (od 1 XI 1539 do XII 1539), gdy ten przeniósł się na biskupstwo kamienieckie. Przy Gądkowskim pracował Zygmunt ze Stężycy, mimo że był profesorem prawa i często sprawował urząd rektora Akademii Krakowskiej - chętnie udzielał się w pracy dla diecezji. Zajął on miejsce w kapitule po Marcinie Bełzie, również profesorze świętych kanonów ${ }^{52}$. Do kapituły został przyjęty z prowizji Gamrata 23 V 1542 r. ${ }^{53}$, do kanonii dodano mu jeszcze kilka beneficjów. Dnia 4 II 1542 r. był instytuowany na prepozyturę sądecką ${ }^{54}$, a 10 VI 1542 r. objął w posiadanie ołtarz św. Katarzyny w kościele Mariackim w Krakowie, gdzie miał również ołtarz św. Tomasza Kantuaryjskiego ${ }^{55}$, posiadał też plebanię we Wrocimowicach. Po śmierci biskupa przemyskiego Stanisława Tarły, kapituła dodała mu beneficjum prestymonialne w Witkowicach ${ }^{56}$. Do obowiązków audytora, które wówczas pełnił Zygmunt ze Stężycy, należało prowadzenie spraw sądowych w kurii w zastępstwie biskupa oraz jego kanclerza, układanie wyroków po-

48 Cap. Crac. k. 104-104', 142-142', 148'-149, 162, 163, 231-232.

49 Cap. Crac. 3 , k. $250-251$.

50 Paweł Sebastian Krassowski z Krassowa małopolskiego, h. Rogala (um. 1543). kanonik krakowski, sekretarz królewski (Wp źródł. II, nr 235, p. 4, s. 178.

51 Cap. Crac. 4, k. 148-149.

52 H. Barycz, Bełza Marcin (ur. 1542), [w:] PSB 1, s. 411-412; Wp źródł. III, nr 3 , p. 1 , s. 2 .

53 Cap. Crac. 3, k. 374.

54 Ep. Crac. 22, k. 113.

55 Tamże, k. 120'.

${ }^{56}$ Dnia 16 I 1545. Cap. Crac. 3, k. 50. 
średnich i stanowczych, a także odczytywanie ich na zakończenie przewodu. Hozjusz do Zygmunta ze Stężycy odnosił się z szacunkiem i współpracował z nim w sprawach dotyczących dobra Kościoła, szczególnie obrony czystości wiary.

Do gorliwych kapłanów w otoczeniu Gamrata należał Paweł Krassowski, który objął kierownictwo konsystorza oficjalatu generalnego krakowskiego po Tomaszu Rożnowskim, oficjale pięciu biskupów, zmarłym 21 I 1540. Krassowski był prepozytem warszawskim i kolegiaty Wszystkich Swiętych w Krakowie, altarystą Swiętych Młodzianków w kaplicy Hinczów w katedrze krakowskiej ${ }^{57}$. Przejściowo po śmierci Mikołaja Bedleńskiego był komisarycznym wikariuszem generalnym (17 IV 7 V 1541). O jego aktywności świadczy spora liczba akt narosłych w ciągu jego 5-letniego urzędowania. Swe obowiązki kapitulne spełniał gorliwie, a nawet na posiedzeniu kapituły dnia 16 IX $1541 \mathrm{r}$. nie wahał się wytknąć swemu koledze w zarządzie diecezji, wikariuszowi generalnemu Benedyktowi Izdbieńskiemu niewypełnianie obowiązków kanonickich przez zaniedbywanie funkcji kanonika hebdomadariusza ${ }^{58}$.

Najwięcej jednak na dworze Piotra Gamrata Hozjusz zbliżył się do Marcina Kromera z Biecza, który w aktach biskupich najpierw jest określany jako servitor biskupa, zaś od r. 1542 stale nazywany mianem secretarius noster ${ }^{59}$. Kromer posiadał kilka beneficjów kościelnych: był kustoszem wiślickim ${ }^{60}$, kanonikiem pułtuskim ${ }^{61}$ i kieleckim ${ }^{62}$. Miał jednak trudności z osiągnięciem kanonii krakowskiej z racji swego plebejskiego pochodzenia. Wprawdzie był wprowadzony na kanonię 30 IV 1543 r. ${ }^{63}$, lecz przez kapitułę został przyjęty dopiero 5 II 1545 r., przy końcu życia Gamrata ${ }^{64}$. Kromer uważał Hozjusza za swego mistrza i dobrodzieja oraz starał się mu służyć na każdym kroku.

W końcu należy wspomnieć nepota Gamratowego Macieja Bala, którym Hozjusz interesował się przez wzgląd na biskupa. Maciej (albo Mateusz) Bal był początkowo dworzaninem biskupim ${ }^{65}$. Po śmierci biskupa Jana Wilamowskiego instytuowano go na Dzierążnię ${ }^{66}$, w rok później po rezygnacji Stanisława Borka został obdarzony kanonią krakowską prebendy wawrzynieckiej ${ }^{67}$. Po roku sam zrezygnował z tejże kanonii ${ }^{68} \mathrm{i}$ w

57 Ep. Crac. 22, k. 313.

58 Cap. Crac. 3 , k. 327.

59 Ep. Crac. 22, k. 121', 185.

60 Cap. Crac. 4, k. $402^{\prime}$.

61 Ep. Crac. 18, k. 402'; 19, k. 574; 22, k. 37; 58, k. 121'.

62 Ep. Crac. 20, k. 37 ;22, k. 115, 190'.

63 Ep. Crac. 22, k. $207^{\prime}-208$.

64 Cap. Crac. 4, k. 71.

65 Ep. Crac. 18, k. $196^{\prime}$.

66 Dnia 13 X 1540. Ep. Crac. 18, k. 365'.

67 Ep. Crac. 18, k. 196'; Cap. Crac. 3, k. 337-337'.

68 Dnia 29 XII 1542. Cap. Crac. 3, k. 397. 
ogóle porzucił stan duchowny. W r. 1545 Maciej Bal był starostą dóbr biskupich $\mathrm{w}$ Iłży ${ }^{69}$, dziesięć lat później wraz z bratem swoim Stanisławem sprowadził do rodzinnej Hoczwi (1556 r.) kaznodzieję kalwińskiego. Maciej do końca życia pozostał wyznawcą kalwinizmu, dopiero jego syn Piotr, założyciel Baligrodu, przeszedł na katolicyzm ${ }^{70}$.

Po śmierci Piotra Gamrata (w swej kamienicy przy ul. Kanoniczej 17), biskupem krakowskim został dawny znajomy Hozjusza z kurii Piotra Tomickiego, a wówczas serdeczny przyjaciel, Samuel Maciejowski $(1546-1550)^{71}$. Już od roku $1531^{72}$ mieszkał on w domu „Swiętego Grzegorza" (Kanonicza 1), który w latach $1531-1534{ }^{73}$ eleganti aedificio przebudował. Hozjusz stał się bliskim członkiem jego dworu, choć nie ulega wątpliwości, że pierwsze miejsce w sercu biskupa zajmował Jan Przerębski ${ }^{74}$, bratanek słynnego Wincentego ${ }^{75}$, biskupa kujawskiego, podkanclerzego Państwa, przyszły prymas. Gdy Maciejowski objął stolicę biskupią w Krakowie, na początku zlecił prowadzenie kancelarii Przerębskiemu, lecz była to funkcja tymczasowa, spełniana tylko przez cztery miesiące (4 IV-2 VIII 1546). Biskup pragnął mieć go przy sobie jako najbliższego powiernika i doradcę $\mathrm{w}$ sprawach kościelnych i politycznych ${ }^{76}$, dlatego przeniósł go z kancelarii, a kanclerzem mianował oddanego sobie Andrzeja Przecławskiego (2 VIII 1546—25 X 1550), ustanawiając go równocześnie kanonikiem krakowskim ". Jan Przerębski, pragnąc mieszkać blisko ordynariusza, objął w bezpośrednim sąsiedztwie dom kapitulny przy ulicy Kanoniczej $3^{78}$, z którego wówczas zrezygnował Feliks Ligęza ${ }^{79}$. Po śmierci siostrzeńca biskupiego Mikołaja Leżeńskiego, mieszkającego w domu „Swiętego Grzegorza”, Maciejowski przyjął na współmieszkańca przy ul. Kanoniczej 1 Jana Przerębskiego ${ }^{80}$, osobę nie mniej drogą, niż zmarły krewny (personam aeque sibi gratam).

Drugim najbliższym domownikiem biskupa Maciejowskiego był kanc-

69 Cap. Crac. 4, k. 75.

70 W. Hejnosz, Bal Matyjasz (um. ok. 1575), [w:] PSB 1, s. 228.

71 W. Dworzaczek, Maciejowski Samuel, h. Ciołek (1499-1550), [w:] PSB 10, s. $64-69$.

72 Cap. Crac. 3, k. $67^{\prime}$.

73 Tamże, k. $114^{\prime}$.

74 J. Korytkowski, Arcybiskupi gnieźnieńscy prymasowie i metropolici polscy, t. III, Poznań 1892 (Korytk. Arcybiskupi III), s. 229-271.

75 Przerębski Wincenty, podkanclerzy państwa, płocki i włocławski biskup, zm. 1515, - por. Korytk. Prałaci III, s. 296-298.

76 Hozjusz pisał o Janie Przerębskim: Vir magno ingenio, doctrina, vitae honestate sacrarumque litterarum peritia insignis - por. L. Eętowski, Katalog biskupów, prałatów i kanoników krakowskich. Prałaci i kanonicy krakowscy (Eętowski, Prałaci), t. III, Kraków 1852, s. 505-510.

77 Instytuowany na kanonię krakowską 6 VIII 1546 (Ep. Crac. 25, k. 140).

78 A. Pankalla, Ligęza Feliks, h. Pótkozic (ok. 1500-1560), [w:] PSB 17, s. 315.

79 Dnia 25 IX 1545 (Cap. Crac. 4, k. 100-100').

80 Dnia 22 XI 1549. Cap. Crac. 4, $342^{\prime}-343$. 
lerz jego kurii (2 VIII 1546—25 X 1550) Andrzej Przecławski, dziekan poznański. Najpierw mieszkał on przy ul. Kanoniczej 14, chcąc być jednak bliżej biskupa, przeniósł się dnia 9 II 1547 r. do domu prźy tejże ulicy, oznaczonego dziś numerem $5^{81}$. Obaj faworyci biskupa Samuela byli egzekutorami jego testamentu ${ }^{82}$, obaj także administrowali diecezją krakowską: Jan Przerębski po śmierci Samuela Maciejowskiego ${ }^{83}$, Andrzej Przecławski po śmierci Andrzeja Zebrzydowskiego ${ }^{84}$.

$\mathrm{Na}$ dworze biskupim w kaplicy „Swiętego Grzegorza” pojawiali się często wysocy urzędnicy diecezjalni: Piotr Myszkowski ${ }^{85}$, wikariusz generalny, i Piotr Porębski, oficjał generalny. Łączyła ich przyjaźń, gdyż obaj pochodzili z terenu oświęcimskiego, obaj byli także kierownikami dwu konsystorzy diecezjalnych. Siedziba ich znalazła się w sąsiedztwie: Piotr Myszkowski mieszkał przy ulicy Kanoniczej 11, a Piotr Porębski pod numerem 13 tejże ulicy ${ }^{86}$. Piotr Myszkowski, wykształcony w Padwie razem $\mathrm{z}$ Klemensem Janickim ${ }^{87}$ u Łukasza Bonamika, władający piękną łaciną klasyczną, zwrócił na siebie uwagę Jana Przerębskiego, pierwszego prałata biskupa Samuela, a po śmierci Maciejowskiego, podkanclerzego państwa (1551). Piotr Przerębski był oficjałem za rządów trzech biskupów: Samuela Maciejowskiego (1546), Andrzeja Zebrzydowskiego (1551-1560) i Filipa Padniewskiego, ale tylko do 1567 roku, bo urząd oficjała został wówczas na stałe połączony ze stanowiskiem wikariusza generalnego, te połączone razem godności pierwszy sprawował Marcin Izdbieński ${ }^{88}$.

Załatwianie spraw diecezjalnych odbywało się nie tylko w obu konsystorzach, ale także w kurii biskupa Maciejowskiego, przy ul. Kanoniczej 1. Sądom przewodniczył sam biskup albo jego kanclerz Jan Przerębski, a po nim Andrzej Przecławski. W ich zastępstwie mógł to czynić audytor Zygmunt ze Stężycy. Funkcję asesorów w kurii Maciejowskiego wykonywali znani nam z audytorium Piotra Gamrata St. Hozjusz, Marcin Kromer, Wojciech Kijowski oraz nowo przybyły Walenty Herburt (Herbolt) ${ }^{89}$, student padewski, późniejszy biskup przemyski i delegat króla na Sobór Trydencki (1562), przyjęty do kapituły krakowskiej

81 Tamże, k. 208.

82 Tamże, k. 381'.

${ }^{83}$ Acta administratoralia Jana Przerębskliego były spisywane od 25 XI 1550 do 7 IV 1551 (Adm. Crac. t. V).

84 Akta administracji Andrzeja Przecławskiego, trwające od 26 VI do 19 VIII 1560 r. są zapisane w Acta officialia 87. w. 382 .

85 L. Hajdukiewicz i H. Kowalska, Myszkowski Piotr, (um. 1591), [w:] PSB 22,

${ }_{86}$ Od r. 1547. Cap. Crac. 4, k. 197, 207'.

87 M. Cytowska, Janicki Klemens (1516-1543), [w:] PSB 10, s. 504-505.

88 W. Urban, Izdbieński Marcin, h. Poraj (1520-1594), [w:] PSB 10, s. 195-196.

89 J. Cynarski, Herburt Walenty, h, wtasnego (1524-1570), [w:] PSB 9, s. 453454. 
przy końcu życia Piotra Gamrata ${ }^{90}$. Silna więź przyjaźni połączyła go z otoczeniem biskupa Maciejowskiego. Szczególnie sprzyjał mu Przerębski i Hozjusz, który nazwał go później: vir et pietate et doctrina praestans ${ }^{91}$. Młodego Herburta polubili bardzo krewni biskupa, których było kilku w Krakowie z rodziny Podlodowskich i Leżeńskich. Jeden z tych pierwszych, Stanisław Lupa, był stolnikiem ziemi sandomierskiej, starosta księstwa siewierskiego i marszałkiem kurii biskupiej Maciejowskiego ${ }^{\mathbf{9 2}}$, drugi - Walenty, był dworzaninem krakowskim (po Stanisławie Lupie objął urząd marszałka ${ }^{93}$ ), trzeci - Jerzy Podlodowski ${ }^{94}$, domownik biskupa Samuela Maciejowskiego, kanclerz Elżbiety, pierwszej żony Zygmunta Augusta ${ }^{95}$, przez jedną noc biskup krakowski (po śmierci Maciejowskiego); król bowiem nazajutrz po złożonej obietnicy decyzję swoją odwołał, dając mu za to pierwszą prałaturę polską, tj. prepozyturę gnieźnieńską. Tak marszałkowie, jak również Jerzy, opiekowali się czwartym pupilem Maciejowskiego Janem Podlodowskim ${ }^{96}$, który w latach 15471549 studiował we Włoszech ${ }^{97}$, po powrocie do kraju zmarł w końcu września 1549 r. ${ }^{98}$ Samuel Maciejowski był najbardziej przywiązany do synów swej siostry Urszuli, zamężnej za Janem Leżeńskim, cześnikiem sandomierskim. Było ich trzech: Jan, Mikołaj i Marian. Jana obdarzył biskup kanonią krakowską ${ }^{99}$, lecz ten zrezygnował $\mathrm{z}$ godności duchownej i wyjechał do Padwy, gdzie w r. 1547 spotykamy go z Erazmem Czuriłą. Mikołaja przyjął wuj dnia 25 IV 1540 r. do kamienicy „Sw. Grze-

90 Walenty Herburt był instytuowany na kanonię krakowską 7 I 1545 (Ep. Crac. 22, k. 278), a przyjęty przez kapitułę dnia 6 I 1545 (Cap. Crac. 4, k. 51-51'),

91 Eętowski, Prałaci III, s. $63-65$.

${ }_{22}$ Ep. Crac. 25, k. 445, 454; 26, k. 124, 452; Cap. Crac. 4, k. 246'.

93 Ep. Cräc. 26, k. 380; 27, k. 41' (r. 1550).

94 Jerzy Podlodowski, h. Janina (um. 1555) - por. Korytk. Prataci III, s. 238.

95 Ep. Crac. 26, k. $121^{\prime}, 480$.

96 Jan Podlodowski, h. Janina, kanonik krakowski, brat Jerzego, referendarza koronnego i prepozyta gnié́nieńskiego, zmarł w r. 1549 (Cap. Crac. 4, k. 329'-330).

97 Cap. Crac. 4 , k. $320^{\prime}$.

98 Cap. Crac. 4, k. $329^{\prime}-330,334$.

99 Jan Leżeński, h. Nałęcz, był synem Jana, kasztelana połanieckiego i Urszuli z Maciejowskich, siostry biskupa Samuela. Do kapituły krakowskiej należał od 18 XII do 7 VIII 1546 (Cap. Crac. 4, k. 124'-125, 157). Rezygnując z krakowskiej kanonii Monetarii dnia 30 VI 1546 ułatwił wejście do kapituły na swe miejsce Jakubowi Niemieczkowskiemu, kanonkowi tarnowskiemu i plebanowi w Stężycy. Dnia 23 V 146 Hozjusz pisał Niemieczkowskiemu: Accipiet illum canonicatum Cracoviensem, quem ei episcopus deferat (Hos. eplae $\mathrm{nr}$ 224). Później Niemieczkowski osiągnął dziekanię i prepozyturę sandomierską (Cap. Crac. 4, k. 163'; E. Majkowski, A. Bastrzykowski, Nieznani prałaci i kanonicy sandomierscy, Kunów 1949, s. 10). Jako dworzanin Jana Tarnowskiego i preceptor jego syna Jana Krzysztofa, Niemieczkowski ani razu nie wziął udziału w posiedzeniu kapituły krakowskiej, do której należał aż do śmierci w r. 1551 (Cap. Crac. 4, k. 427). Dnia 18 XII 1546 ustąpił swej Monetarii Dionizemu Secygniowskiemu, kanonikowi kieleckiemu (Cap. Crac. 4, k. 194'), który jako dworzanin Samuela Maciejowskiego (Ep. Crac. k. 5) był plebanem w Słaboszowie (Ep. Crac. 25, k. 91) i prebendarzem św. Benedykta na Krzemionkach (Ep. Crac. 29, k. 131). Secygniowski przyjaźnił się z Filipem Padniewskim (tamże, k. 132). Był następcą na biskupstwie kamienieckim Leonarda Słończewskiego (4 VI 1563-1569) — por. HE 148. 
gorza" na wspólne mieszkanie ${ }^{100}$. Mikołaj ciężko zachorował, dlatego Maciejowski przeniósł go z tej tętniącej życiem kamienicy kurialnej do domu przy ul. Poselskiej 12, gdzie po niecałym miesiącu (przed 8 XI 1549 r.) zmarł, a kanonię i kamienicę po nim otrzymał trzeci z Leżeńskich - Marian ${ }^{101}$. Życzliwy Marianowi wuj biskup Samuel do kanonii krakowskiej dołożył wieś biskupią Posądzę ${ }^{102}$. Hozjusz przez przyjaźń do Maciejowskiego serdecznie się Leżańskimi opiekował. Gdy sam został biskupem chełmińskim, kanonię sandomierską odstąpił Marianowi Leżeńskiemu ${ }^{103}$. W roku 1557 Marian udał się na studia do Włoch, następnie przedsięwziął podróż do Ziemi Swiętej. Dnia 7 XII 1559 r. kapituła krakowska otrzymała wiadomość, że Marian umarł in peregrinatione Jerosolimitana ${ }^{104}$

Do przyjaciół Hozjusza należał wówczas Stanisław Słomowski ${ }^{105}$, który niegdyś był serwitorem biskupa P. Tomickiego ${ }^{106}$. Związany z Andrzejem Zebrzydowskim, Słomowski nie był domownikiem Maciejowskiego, ale nieraz odwiedzał jego kurię. Razem ze Słomowskim był Stanisław Przeborowski ${ }^{107}$, człowiek mało wartościowy; wykorzystując dawną znajomoć narzucał się on biskupowi Maciejowskiemu, a także Hozjuszowi.

Pochodzący ze starożytnego rodu Toporczyków Paweł Tarło ${ }^{108}$ marzył zapewne o biskupim awansie, dlatego trzymał się blisko kanclerza Maciejowskiego, a potem usłużny i miły łatwo przyjął się na dworze biskupa krakowskiego. Biskup wprowadził go do kapituły krakowskiej, która go przyjęła jako swego członka 2 X 1549 r. ${ }^{109}$

Mówiąc o dworze biskupa krakowskiego Samuela Maciejowskiego trzeba wspomnieć Andrzeja Spota, opata wąchockiego i mogilskiego. Dnia 23 III 1547 r. został biskupem laodycejskim i sufraganem krakowskim ${ }^{110}$. Od biskupa Maciejowskiego dostał $\mathrm{w}$ darze na utrzymanie wieś Maciejowice koło Luborzycy ${ }^{111}$.

$\mathrm{Na}$ około 70 prałatów i kanoników, którzy przesunęli się przez kapi-

${ }^{100}$ Mikołaj Leżeński, h. Nałęcz, syn Jana, cześnika sandomierskiego i Urszuli z Maciejowskich.

101 Cap. Crac. 3, k. 253-254.

102 Dnia 14 II 1550 (Cap. Crac. 4, k. 355').

103 Ep. Crac. 26, s. 363.

104 Cap. Crac. 5, k. 363.

105 Stanisław Słomowski, kanonik gnieźnieński i krakowski, sekretarz królewski, biskup sufragan krakowski i arcybiskup lwowski, zmarł 22 IX 1575 (Korytk. Prałaci III, Gniezno 1883, s. 344-546).

106 Ep. Crac. 11, k. 317.

107 Stanisław Przeborowski, h. Abdank, kanonik krakowski, mieszkający przy ul. Kanoniczej 9, zmarł w r. 1549. Cap. Crac. 4, k. 204-205.

108 Paweł Tarło, h. Topór, kanonik krakowski, dziekan przemyski, arcybiskup lwowski (1561-1565) - por. Ep. Crac. 25, k. 371.

109 Cap. Crac. 4, k. 329'-330.

$110 \mathrm{HE}$ III, 218.

111 Cap. Crac. 4, k. 362. 
tułę krakowską w czasie przynależności do niej Stanisława Hozjusza, połowa z nich nosiła tytuł sekretarza królewskiego. Niektórzy z tych sekretarzy należeli do dworów biskupich, niektórych zaś spotykał Hozjusz tylko w kancelarii królewskiej. Więzy przyjaźni najłatwiej nawiązywał Hozjusz z sekretarzami zbliżonymi do otoczenia biskupów, z innymi spotykał się tylko na drodze urzędowej. Do wyjątków należał Andrzej Czarnkowski. Nie będąc nigdy dworzaninem biskupim, cieszył się przyjaźnią Hozjusza, z którym razem studiował w Bolonii i w Padwie. Czarnkowski znalazł poparcie u biskupa Maciejowskiego, gdy ten chroniąc go, naraził Kraków w r. 1549 na wyjście żaków. Przez wdzięczność Czarnkowski zamyślał rozpocząć starania o kapelusz kardynalski dla $\mathrm{Ma}-$ ciejowskiego. Pierwszy prałat domowy biskupa Maciejowskiego Jan Przerębski zostawszy wicekanclerzem Państwa zaprotegował go w 1553 r. na biskupstwo poznańskie. Czarnkowski był wraz z Hozjuszem delegatem kapituły krakowskiej na synod piotrkowski w r. $1548{ }^{112}$.

Biskup Maciejowski bardzo cenił Rafała Wargawskiego, administratora salin wielickich, a potem notariusza skarbu i sekretarza królewskiego, przyjętego do kapituły krakowskiej 17 VIII 1548 r. ${ }^{113}$

Przyjęła się opinia, że posada sekretarza królewskiego była odskocznią do objęcia wyższych godności kościelnych. To prawda, bo godności te (biskupstwa i ważniejsze kanonie) król i królowa rozdawali ludziom im oddanym, w nadziei że będą podatnym narzędziem politycznym w rękach królewskich, czego już przedtem doświadczono. Dlatego ambitne duchowieństwo z całej Polski, marzące o awansach kościelnych, zdążało w stronę Krakowa, aby tu szukać swojej szansy życiowej. Nic dziwnego, że w tych warunkach kapituła krakowska stała się seminarium episcoporum, bo każdy dworak, trzymający się blisko zamku królewskiego, dążył do zdobycia materialnej podstawy utrzymania, jaką stanowiły beneficja kościelne. I tak np. Feliks Ligęza, wesoły kompan lubiący zabawy i huczne biesiady, dzięki czepianiu się pańskiej klamki otrzymał koadiutorię, a potem nawet arcybiskupstwo lwowskie. Z dziesięcioletniego pobytu Stanisława Hozjusza w kapitule krakowskiej z 70 prałatów i kanoników zasiadających $\mathrm{w}$ stallach katedralnych aż 21 zostało biskupami (czterech z nich otrzymało godność arcybiskupią). Byli to: Erazm Ciołek (z Mogiły), Andrzej Czarnkowski, Jan Drohojewski, Walenty Herburt, Stanisław Hozjusz, Benedykt Izdbieński, Marcin Kromer, Feliks Ligęza, Samuel Maciejowski, Piotr Myszkowski, Filip Padniewski, Jan Przerębski, Dionizy Secygniewski, Stanisław Słomowski, Andrzej Spot, Paweł

112 Cap. Crac. 4, k. 241'. Przy końcu lutego 1546 r. Hozjusz w imieniu Maciejowskiego polecał królowi kandydaturę A. Czarnkowskiego na wakujące stanowisko biskupa poznańskiego (Hos. eplae I, s. 205-206).

${ }_{113}$ Rafał Wargawski, h. Rola, kanonik krakowski, prepozyt sandomierski, włocławski kustosz, sekretarz królewski, zmarł przed 15 II 1561 r. (Cap. Crac. 5, k. 425'). 
Tarło, Stanisław Tarło, Jakub Uchański, Andrzej Zebrzydowski, Jan Wilamowski i wprawdzie nie kanonik, ale długoletni kaznodzieja katedralny - Leonard Słończewski.

Oprócz dworzan biskupich i królewskich trzecią grupę wyróżniającą się w środowisku kapitulnym i bardzo interesującą Hozjusza stanowili intelektualiści. Nie ograniczali się oni do młodzieńczych studiów krajowych czy zagranicznych, lecz dalej podtrzymywali swe zainteresowania naukowe. Pomijam tych, którzy uważając się za humanistów, ze wzgardą patrzyli na scholastykę (scholasticitas), zajmowali się nowinkami religijnymi oraz często prowadzili swobodny tryb życia.

Do intelektualistów w kapitule krakowskiej na pierwszym miejscu należy zaliczyć dwóch późniejszych biskupów warmińskich: St. Hozjusza i Marcina Kromera. Obaj posiadali doktorat obojga praw zdobyty w Bolonii, ale w swej pracy naukowej nie ograniczali się do wyuczonej dyscypliny, lecz rozszerzali swe zainteresowania na inne dziedziny teologii; Marcin Kromer zajmował się także historią. Oprócz tych dwóch naukowców, kapituła krakowska miała znakomitych prawników praktyków, sekretarzy królewskich, mianowicie Jerzego Myszkowskiego, który dzięki wybitnej znajomości prawa był wybierany do państwowych komisji, mających na celu korekturę dotychczasowego ustawodawstwa, oraz Jakuba Uchańskiego ${ }^{114}$, który dostawszy się dzięki protekcji Jana Tęczyńskiego na dwór królewski, stał się doradcą monarchy i przez 12 lat był referendarzem koronnym ${ }^{115}$. Gdy Hozjusz wszedł do kapituły, było w niej jeszcze dwóch prawników starej daty: Mikołaj Bodleński i doktor praw Stanisław Borek. Pierwszy z nich umarł po dwóch miesiącach, drugi zaś był zajęty w kapitule troską o ortodoksję katolicką, co w czasie reformacji nie było łatwym zajęciem. Prawnikiem był również Maciej Łącki ${ }^{116}$, scholastyk włocławski. Przyjęty do kapituły krakowskiej w r. 1547, dopiero 4 II 1549 r. pokazał się w kapitularzu krakowskim ${ }^{117}$. Działalność prawniczą w Krakowie rozwinął dopiero po odejściu stamtąd Hozjusza.

Diecezji i kapitule najwięcej mogli służyć miejscowi prawnicy związani z uniwersytetem, wchodzący jako doktorzy do kapituły na prebendy plebejskie. Do nich należał Mikołaj z Koprzywnicy ${ }^{118}$, który po śmierci żony przyjął święcenia kapłańskie i otrzymał kanonię krakowską;

114 Jakub Uchański, h. Radwan, kanonik krakowski, referendarz koronny, biskup chelmski i kujawski, arcybiskup gnieźnieński (1562-1581): por. T. Wierzbowski, Uchańsciana, Warszawa 1884-1895; Korytk. Arcybiskupi IV, s. 272-418; Pociecha, Królowa Bona III, s. 161, 165.

115 Jakub Uchański mało oddawał usług kapitule i diecezji krakowskiej. Podobnie jak Filip Padniewski, nie znosił takich gorliwców, jak biskup Samuel Maciejowski i Hozjusz.

${ }_{116}$ Maciej Łącki, h. Lis (1505-1557) - por. Wp źródł. III, nr 355, p. 1, s. 192;

L. Hajdukiewicz, [w:] PSB 18, s. $307-308$.

117 Cap. Crac. 4, k. 295'. 
zbytnio zajęty swą rodziną niewiele był kapitule przydatny. Jego następca na kanonii Marcin Bełza z Krakowa, zaledwie kilka miesięcy w $r$. 1542 był kanonikiem krakowskim ${ }^{119}$. Dopiero przyjęty z prowizji biskupa Piotra Gamrata na prebendę prawniczą dnia 23 V 1542 r. Zygmunt ze Stężycy ${ }^{120}$, oddał się całą duszą posłudze diecezjalnej jako audytor kurii i członek rozlicznych komisji ustanawianych przez kapitułę. Hozjusz bardzo cenił tego skromnego, pracowitego kapłana, który całkowicie poświęcił się służbie Kościoła.

Prebendę teologa w czasach Hozjusza posiadał plebejusz doktor Stanisław Biel z Nowego Miasta koło Przemyśla ${ }^{121}$. Gdy Hozjusz wchodził do kapituły krakowskiej, Biel był już zgrzybiałym starcem, ale otoczonym szacunkiem jako człowiek światły, zwolennik humanizmu, a zarazem filar ortodoksji katolickiej obok Mikołaja Bedleńskiego. Po śmierci Biela zajął jego miejsce jako professor sacrarum litterarum w kapitule znany z gorliwości kościelnej (podobnie jak jego poprzednik) kaznodzieja katedralny Jakub z Kleparza. Bywał on członkiem komisji inkwizycyjnych, pełnił funkcję diecezjalnego penitencjarza generalnego i wyznaczał spowiedników na jubileuszowe uroczystości katedralne. Hozjusz często z nim współdziałał w sprawach dyscypliny kościelnej.

$\mathrm{Na}$ dworze biskupim i królewskim Hozjusz stykał się ze światem lekarskim. W otoczeniu Gamrata poznał trzech medyków. Pierwszym z nich był osobisty lekarz biskupa Piotra Jakub z Biskupic (Biskupski, Pontificius) ${ }^{122}$, padewski doktor sztuk wyzwolonych i medycyny, który nie odstępował Gamrata aż do końca jego życia, choć równocześnie leczył króla Zygmunta I, królowę Bonę i ich syna Zygmunta Augusta. W r. 1540 pomagał mu lekarz Jan Noskowski ${ }^{123}$, człowiek świecki, a w r. 1543 przyłączył się do niego Bartłomiej Sabinka ze Stradomia (Regiopontanus), kustosz kolegiaty Św. Idziego w Krakowie ${ }^{124}$. Jan z Biskupic ${ }^{125}$ osiągnął kanonię krakowską przy końcu życia Gamrata z jego nominacji (24 III 1543 r.) na prebendę wakującą po śmierci Mikołaja Mił-

118 Mikołaj z Koprzywnicy, mlodszy (um. 1542), profesor, prawnik i rektor Akademii krakowskiej - por. Wp źródł. II, nr 89, p. 2, s. 79; L. Hajdukiewicz, [w:] PSB 21, s. $115-116$.

119 Marcin Bełza (Belze), kanonik krakowski, doktor iuris pontifici, umarł niespodziewanie w maju 1542 r.; zamyślał wobec kapituły ustanowienie dla siebie anniwersarza, a zmarł przed dniem 20 tego miesiąca (Cap. Crac. 3, k. 370-370', $372)$.

${ }_{120}$ Zygmunt ze Stężycy przyjęty do kapituły krakowskiej dnia 23 V 1542 (Cap. Crac. k. 374).

121 H. Barycz, Biel Stanisław (Albinus), um. 1541, [w:] PSB 2, s.32; WP źródl. III, nr 176, p. 1, s. 101 .

122 S. Eempicki, Jakub z Biskupic, zwany Pontificus (um. 1554), [w:] PSB 2, s. $109-110$.

${ }_{123}$ Ep. Crac. 22, k. 14; J. Bieniarzówna, Noskowski Jan. h. Nałęcz (1478-1542),

[w:] PSB 23, s. 224.

124 Ep. Crac. 22, k. 200; 26, k. 55'.

125 Ep. Crac. 21, k. 307; 22, k. 296'-297.

33 - Analecta Cracoviensia 
kowskiego ${ }^{126}$, Sabinka zaś dopiero po zgonie Samuela Maciejowskiego ${ }^{127}$. Fizykiem biskupa Samuela był Marcin Borucki ${ }^{128}$, doktor sztuk i medycyny, tytułujący się także fizykiem królewskim.

Do kapituły krakowskiej wchodzili także lekarze królewscy; od r. 1546 starał się o przyjęcie do niej Jan Benedyktynowicz (Joannes Benedicti) ${ }^{129} \mathrm{z}$ Głogowa albo z Treblow lub Trebul, diecezji miśnieńskiej, nazwiskiem Solfa, boloński doktor medycyny. Kapituła, nie mając pewności co do jego szlachectwa, odmawiała mu instalacji. Dopiero gdy cesarz Ferdynand poświadczył jego szlachectwo, kapituła dnia $18 \mathrm{~V} 1547 \mathrm{r}$. dopuściła go do swego grona ${ }^{130}$, zmuszając Jana Czermieńskiego ${ }^{131}$ do rezygnacji ze spornej kanonii.

Lekarza Solfę przewyższał sławą i znaczeniem Giovanni Andrea Valentino ${ }^{132}$, patrycjusz modeński, kanonik i prepozyt krakowski, wielki sekretarz koronny, lekarz rodziny królewskiej. Na dworze biskupów krakowskich nie bywal, jednak biskup Gamrat - chociaż z jego usług niewiele korzystał — odnosił się do niego życzliwie; 17 X 1539 r. złożył mu dar w postaci dziesięcin biskupiego stołu ${ }^{133}$. Hozjusz zatrudniony w kancelarii zamkowej utrzymywał biskupie kontakty z Giovannim Andrea Valentino, a po jego śmierci optował dom zajmowany przez Valentino przy ul. Kanoniczej 18. Jak wyżej wspomniano, Hozjusz początkowo mieszkał przez trzy lata (1540-1543) w Krakowie przy ul. Kanoniczej 8, po śmierci zaś Kaspra Podłęskiego ${ }^{134}$ przeniósł się do domu przy ul. Poselskiej 12 (w maju 1543 r.) i dom ten odnowił wielkim kosztem ${ }^{135}$. Podobna sytuacja była przy ul. Kanoniczej 18; opływający w bogactwa doktor Giovanni Valentino zostawił kamienicę częściowo zrujnowaną po po-

${ }^{126}$ Mikołaj Miłkowski, doktor obojga praw, kanonik krakowski, zmarł w marcu 1545 r., pogrzeb odbył się 26 III 1545 (Cap. Crac. 4, k. 63'-64).

${ }_{127}$ Bartłomiej Sabinka (Sabinus), archidiakon lubelski i kanonik krakowski, lekarz nadworny króla Zygmunta Augusta, zmarł -w r. 1556 - por. Eętowski, Prataci IV, s. $24-25$.

128 Ep. Crac. 26, k. 128, 317.

129 Cap. Crac. 4, k. $141^{\prime}, 166$.

130 Jam Benedicti Solfa wziął prebendę topolską po Andrzeju Zebrzydowskim (Wp. Crac. 25, k. 419). Umarł przed 14 IV 1564. Cap. Crac. 5, k. 494'-495'.

131 Jan Czermiński, sekretarz królewski, z nominacji królowej Bony przyjęty na prebendę topoliską w. kapitule krakowskiej dnia 21 XI 1545 (Cap. Crac. 4, k. 121'-122). Był jednak zmuszony zrezygnować z niej $18 \mathrm{~V} 1547$ na rzecz Jana Solfy (Ep. Crac. 25, k. 419), ale już 14 II 1547 wziął prebendę łazowską. Zmarł przed 13 X 1551 (Cap. Crac. 5, k. 23').

${ }_{132}$ Giovanni Andrea Valentino da Modena, doktor sztuk wyzwolonych i medycyny (ok. 1495 - 20 II 1547) - por. Wp źródł. III, nr 261, s. 151; W. Pociecha, Królowa Bona I, Poznań 1949, s. 242; II s. 58-65; S. Pańków, Jan Andrzej de Valentinis (Valentino), [w:] PSB 10, s. 439.

${ }^{133}$ Cap. Crac. 3 , k. $238^{\prime}$.

134 Kasper Podłęski, kanonik krakowski, dziekan kolegiaty Wszystkich Swiętych w Krakowie, pierwszy prepozyt kolegiaty bobowskiej (um. 1543) - por. Wp źródł. III, nr 103, p. 3, s. 59 .

185 Cap. Crac. 3, k. 418-418'. 
żarze w r. $1544^{136}$. Hozjusz wprowadził się do nowego domu 24 III 1547 r. ${ }^{137}$, a pożegnał go w r. 1550, wyjeżdżając na biskupstwo chełmińskie.

\section{WZAJEMNE WSPOEŻYCIE PRAŁATOW I KANONIKOW KRAKOWSKICH ZA CZASOW KANONIKATU STANISEAWA HOZJUSZA}

Członkowie kapituły krakowskiej spotykali się przede wszystkim w chórze katedry na Wawelu przy wypełnianiu obowiązków służby Bożej, a także na ul. Kanoniczej, gdzie po większej części mieszkali i odwiedzali się w swoich kuriach kanonickich, skąd wyjeżdżali w zmieniających się grupach jako delegaci kapituły na synody i na sejmy, lub brali udział w różnych komisjach wyznaczanych w celu rewizji majątków kapitulnych oraz ich granic, zabudowań gospodarczych i domów. Kapituła będąc właścicielem sporego obszaru majątkowego, jakim była regencja pabianicka, nierzadko wysyłała w tamte strony grupę wybranych swoich członków, celem przeprowadzenia inspekcji zarządu tych dóbr. Kilkudziesięciu prałatów i kanoników kapituły krakowskiej pracowało w kancelarii królewskiej w roli sekretarzy i to również stanowiło pewien element życià wspólnego. Najbardziej ważkie znaczenie w budowaniu wspólnoty kolegium kanonickiego odgrywały zebrania całej kapituły w pełnym składzie trzy razy w roku na tak zwanych kapitułach generalnych, które odbywały się $w$ ustalonych terminach: $z$ okazji święta Oczyszczenia NMP (2 II) oraz św. Stanisława w maju (8 V) i we wrześniu (27 IX). Odbywały się także cotygodniowe posiedzenia kapituły, ale w nich zwykle brała udział tylko niewielka ilość członków kapituły, wolnych od pilnych zajęć.

$\mathrm{Na}$ posiedzeniu generalnym kapituły mogło brać udział na raz 36 osób; zawiązywały się przyjaźnie, ale też pojawiały się sprzeczności, tak między poszczególnymi kanonikami, jak i grupami. Różne były przyczyny urażenia ambicji, nieraz na tle rywalizacji budziły się wzajemne niechęci. Zdarzały się wypadki zniewagi słownej, o co wśród dumnej szlachty zasiadającej w stallach kanonickich nie było trudno. Dochodziło też do zatargów na tle majątkowym.

Grupowe zbliżenia przyjacielskie najczęściej tworzyły się między prałatami i kanonikami na dworach biskupich. Te zespoły występujące w otoczeniu biskupów P. Tomickiego, J. Chojeńskiego, P. Gamrata i S. Maciejowskiego (do których należał Stanisław Hozjusz) zostały przedstawione w I rozdziale. Należy tu przynajmniej wspomnieć o zespole otaczającym biskupa Jana Latalskiego (15 III 1536-17 VIII 1537). Grupa

136 Cap. Crac. 4, k. $7-8$.

137 Tamże, k. 216'-217. 
ta stanowi zupełnie inny świat humanistów w kapitule krakowskiej i nie włączyła się do późniejszych dworów P. Gamrata i S. Maciejowskiego; dlatego pozostała obca Hozjuszowi. W zespole, z którym był związany Hozjusz, członkowie kapituły byli wzorowymi kapłanami, czystego życia, oddanymi Kościołowi i wierze katolickiej, tylko Benedyktowi Izdbieńskiemu można było zarzucić przywłaszczanie sobie cudzego mienia, a pod względem dyscypliny celibatu jedynym niechlubnym wyjątkiem był Stanisław Przeborowski, prowadzący rozwiązłe i hulaszcze życie ${ }^{138}$, którego obecność tolerowano w zespole ze względu na dawną znajomość, sięgającą jeszcze czasów biskupa Piotra Tomickiego.

Tym humanistom z obozu Hozjusza trzeba przeciwstawić drugą grupę, bardziej laicką, która w imię postępu humanistycznego odwróciła się od wzgardzonej scholastyki, grzeszyła brakiem dobrych obyczajów i swobodą w wyrażaniu krytyki wobec hierarchii i urządzeń kościelnych. Do tej grupy należał: Feliks Naropiński ${ }^{139}$, kanclerz biskupa Latalskiego, dziekan włocławski, ze swym bratem Janem Naropińskim; Melchior Sobek ${ }^{140}$, siostrzeniec Krzysztofa Szydłowieckiego, do którego się później przyłączył jego brat Zygmunt Sobek ${ }^{141}$; Mikołaj Miłkowski, sekretarz Latalskiego ${ }^{142}$; Kasper Podłęski i jego koadiutor Stanisław Wolski ${ }^{143}$. Do tej grupy należy także zaliczyć przyszłych biskupów: Jana Uchańskiego, Andrzeja Zebrzydowskiego ${ }^{144}$, Jana Drohojowskiego (Drojowskiego) ${ }^{145}$. Małą gorliwością kapłańską w kapitule zaznaczyli się tacy

138 Cap. Crac. 3 , k. $185^{\prime}-186$; k. $204^{\prime}$.

139 Feliks Naropiński, h. Belina, kanonik gnieźnieński i krakowski, niepohamowany lowca beneficjów kościelnych, gdy natrafił na utrudnienia w swych zamiarach, nie cofał się przed gwałtownymi wystąpieniami. Umarł 21 XI $1541 \mathrm{r}$. W Rrzymie, podczas procesu przeciw kapitule krakowskiej (H. Kowalska, Naropiński Feliks, [w:] PSB 22, s. 548-549).

${ }_{140}$ Melchior Sobek z Sulejowa, h. Brochwicz (um. 1542), od r. 1523 prepozyt stopnicki, od r. 1527 kanonik krakowski. Człowiek wyniosły i trudnego charakteru (Eętowski, Prałaci IV, s. 62).

${ }_{141}$ Zygmunt Sobek, brat Melchiora i Balcera Sobka z Sulejowa, starosty soleckiego, kanonik gnieźnieński i krakowski, pielgrzym do Ziemi Swiętej. Umarł w sierpniu 1550 r. (Korytkowski, Prałaci III, s. 547-548).

142 Esp. Crac. 16, k. 43'.

143 Stanisław Wolski, h. Półkozic, syn Mikołaja, ochmistrza królowej Bony, koadiutor kanonii krakowskiej przyjęty przez Kaspra Podłęskiego w r. 1537. Od r. 1543 kustosz krakowski. W 1551 zrezygnował ze stanu duchownego i objął urząd marszałka dworu Zygmunta Augusta. Wraz z bratem Mikołajem, biskupem włocławskim, walczyl przeciw koncepcji Jakuba Uchańskiego zwolania synodu narodowego. Stanisław Wolski był ojcem Mikołaja, fundatora Bielan krakowskich (Eętowski, Prałaci IV, s. 238).

144 Andrzej Zebrzydowski, h. Radwan. kolejno biskup kamieniecki, chełmski, kujawski i krakowski. Umarł w r. 1560 (Korytk., Prałaci IV, s. 454-481).

${ }_{145}$ Jan Drohojowski (Drojowski) h. Korczak, kanonik krakowski, sekretarz królewski, kolejno biskup kamieniecki, chełmski i kujawski. Człowiek światowy, w swym otoczeniu miał Frycza Modrzewskiego, Stanisława Orzechowskiego, za kanclerza zaś J. Turobina. Chwiejny w wierze, uciskał poddanych. Umarł w Wolborzu 1557 r. - por. S. Kot, Drohojowski Jan (ok. 1505-1557), [w:] PSB 5, s. 380-381. 
kanonicy, jak: Jan Drzewicki ${ }^{146}$, Jan Konarski, prepozyt kolegiaty św. Michała na Zamku ${ }^{147}$, Hieronim Rosborski ${ }^{148}$, Wilhelm Jarocki ${ }^{149}$ i Jan Łaski, prepozyt gnieźnieński ${ }^{150}$.

W kapitule tworzyły się praktyki dobierania przez kanoników tzw. koadiutorów z prawem następstwa, którzy po śmierci lub ustąpieniu danego kanonika wchodzili na jego miejsce. Tak np. Kasper Podłęski przyjął za koadiutora Stanisława Wolskiego ${ }^{151}$, Jan Łaski, prepozyt gnieźnieński - Macieja Zieleńskiego ${ }^{152}$, wiernego sługę jego rodziny, Mikołaj Bedleński, wikariusz generalny, przybrał za swego pomocnika przy scholasterii krakowskiej Jana Naropińskiego, prawdopodobnie swego krewnego. Inną formą dzielenia się dobrami kanonii i oznaką życzliwości było dopuszczenie do wspólnoty (solidum) kurii kanonickiej innego kanonika, który po odejściu pierwszego właściciela zwykle tę kurię obejmował, np. wspomniany wyżej Bedleński oddał zamieszkiwaną przez siebie kamienicę (ul. Kanonicza 15) in solidum Benedyktowi Izdbieńskie$\mathrm{mu}$, jakby w przeczuciu, że po jego śmierci tenże nadal będzie prowadził w jego kurii konsystorz wikariatu generalnego.

Wskazawszy w ogólny sposób, jakie w łonie kapituły krakowskiej powstawały podziały w czasach kanonikatu Hozjusza, trzeba w dalszym ciągu przedstawić, jakie one $\mathrm{w}$ gronie kapitulnym powodowały napięcia, które niejednokrotnie wyładowywały się w przykrych, a nawet publicznych incydentach. Najwięcej wstrząsnął kapitułą krakowską w tym o-

146 Jan Drzewicki, h. Ciołek, kanonik krakowski, scholastyk łęczycki. Podejrzany w wierze, umarł w Padwie 7 XII 1559 (Cap. Crac. 5, k. 363' i 364).

147 Jan Konarski, h. Abdank, kanonik krakowski, prepozyt kolegiaty św. Michała na Wawelu. Chwiejny w wierze i swobodnych obyczajów (Wp źródł. III, nr 67 , p. 2, s. 39).

148 Hieronim Rosborski był kanonikiem krakowskim od r. 1533. W r. 1538 wyjechał na studia do Italii (Cap. Crac. 3, k. 187'), gdzie nabawił sie nieuleczalnej choroby, na skutek której nie mógł spełniać obowiązków kapłańskich i kapitulnych. Był karany przez kapitułę. Choroba, która go dręczyła, położyła kres jego życiu przed 9 XI 1551 (Cap. Crac. 5, k. 26'). Mieszkał w domu Długosza po Bernardzie Wapowskim, a po nim wprowadził się do tego domu Walenty Herburt, prepozyt przemyski.

149 Wilhelm Jarocki, h. Rawicz, syn Stanisława, marszałka koronnego, krewniak prymasa Jana Łaskiego, kanonik krakowski w r. 1531 mianowany przez Bonę, stojący w kapitule za czasów Hozjusza najniżej pod względem moralnym. Publiczny konkubinariusz. Źle traktował służbę. W swym domu, leżącym w Zaułku św. Piotra (wschodnie ramię ul. Poselskiej) zasztyletował człowieka, kstórego następnie wyrzucił na podwórze, gdzie tenże skonał na gnoju. Jarocki zmarł w Krakowie 22 V 1546 (Cap. Crac. 4, k. 158').

150 Jan Łaski, h. Korab, bratanek prymasa Jana Łaskiego, syn Jarosława, prepozyt gnieźnieński, kanonik knakowski, sekretarz królewski. W r. 1540 zerwał z Kościołem Katolickim - por. H. Kowalska, Easki Jan, h. Korab (1499-1560), [w:] PSB 18, s. 237-244; Wp źródł. III, nr 72, s. 42.

151 Dnia 27 VII 1537 (Cap. Crac. 3, k. 175-175').

152 Maciej Zieleński, kanonik poiznański, pleban w Opatoweu, koadiutor Jana Easkiego (Cap. Crac. 3, k. 148-148' 2 VI 1536). Po pewnych trudnościach ostatecznie przyjęty do kapituły krakowskiej dnia 16 III 1545 (Cap. Crac. 3, k. 409). Zmarł w r. 1553. (Cap. Crac. 5, k. 48', 105). 
kresie zatarg kapituły z kanonikiem Janem Naropińskim, którego Mikołaj Bedleński wziął za koadiutora swej prałatury scholasterii przy katedrze na Wawelu. Po śmierci Bedleńskiego, biskup Gamrat - zgodnie z wolą kapituły - oddał scholasterię krakowską nie Janowi Naropińskiemu, koadiutorowi tejże prałatury, lecz swemu faworytowi Włochowi Antoniemu de Monte Cinere. Ten jednak, przewidując kłopoty z koadiutorem, czym prędzej zamienił się tą godnością — jak wyżej wspomniano - z Andrzejem Czarnkowskim, na którego kanonię został przyjęty przez kapitułę dnia 22 IV $1540 \mathrm{r}^{153}$, lecz niedługo potem kapituła zagrożona karami kościelnymi instalowała na scholasterię również i Jana Naropińskiego, który jako koadiutor miał za sobą prawo ${ }^{154}$.

Tu się okazuje niedoskonałość ówczesnego obsadzania beneficjów: każdego, kto miał odpowiednie warunki (pochodzenie szlacheckie i święcenia) oraz okazał dokument prezenty, prowizji czy konfirmacji koadiutorii, kapituła przyjmowała z obawy przed ewentualną ekskomuniką, umożliwiając kandydatom popieranym przez różnych kolatorów czy patronów uzyskane drogą procesu spokojnego posiadania (pacificia possessio) beneficjum kościelnego. Katedra krakowska otrzymała więc dwóch scholastyków, z tym że Czarnkowski pierwszy zajął stallę w chórze i majątek należący do scholasterii Mistrzejowice ${ }^{155}$. W tej sytuacji Jan Naropiński,' mając dokument koadiutorii, łatwo się wystarał w Rzymie o monitorium dla biskupa Gamrata, które odczytał na posiedzeniu kapituły dnia 5 X 1540 r. ${ }^{156}$, a następnie zgłosił się z nim do domu biskupa, ale nie został przyjęty. Wówczas Naropiński, człowiek popędliwego usposobienia i zawzięty, postanowił użyć katedry wawelskiej za theatrum swego wystąpienia przeciw biskupowi. Dnia 17 X 1540 r., gdy Gamrat z kaplicy Trójcy Świętej wyszedł celebrawać mszę św., Naropiński poprowadził go na stronę konfesji-św. Stanisława, czyniąc mu po drodze głośno wyrzuty, że go nie chciał przyjąc z monitorium karnym w sprawie scholasterii krakowskiej ${ }^{157}$. Na wniesioną + za pośrednictwem audytora Zygmunta ze Stężycy - skargę Gamrata kapituła w dniu 29 X 1540 r. za karę pozbawiła Naropińskiego codziennych posiłków w refektarzu i odebrała mu prawo wstępu do kapitularza, żądając przeproszenia Gamrata ${ }^{158}$. Naropiński był nieugięty. W procesie stracił wieś prestymonialną Dziekanowice, którą kapituła przydzieliła swemu dziekanowi Janowi Zbąskiemu ${ }^{159}$, majątek prebendy kanonickiej przez pewien czas

${ }^{153}$ Cap. Crac. 3, k. 252-252'.

154 Tamże, k. $254-255$.

155 Tamże, k. 251'-252', 318-318'.

156 Tamże, k. 269 a'.

157 Tamże, k. $280-282$ '.

158 Tamże.

159 Jan Zbąski, h. Nałęcz, dziekan krakowski, prepozyt poznański, sekretarz królewski, zmarł 31 XII 1542 (Cap. Crac. 3, k. 302'). 
był w sekwestrze, a nawet został mu zabrany dom wielkim kosztem odbudowany na Wawelu ${ }^{160}$. Do tego kolega z kapituły Stanisław Przeborowski rozszerzał o Naropińskim złośliwe paszkwile (libri famosi) i wykradł mu ryby ze stawu we wsi Rudawa ${ }^{161}$.

Zacięty w uporze Jan Naropiński jeszcze raz w katedrze krakowskiej zrobił skandaliczną awanturę. Tym razem zaatakował wikariusza generalnego Benedykta Izdbieńskiego 29 VIII 1541 r., w czasie pogrzebu Stanisława Biela, profesora teologii. Niepomny powagi chwili, Naropiński napadł obelżywymi słowami wikariusza ${ }^{162}$, a poza katedrą dopuścił się rękoczynu. W zapamiętałej wymianie ciosów wybili sobie zęby ${ }^{163}$. Naropiński nie darował także i kanclerzowi Gamrata Bartłomiejowi Gądkowskiemu. Za fizyczną napaść na kanclerza Naropiński, któremu przedtem chwilowo złagodzono karę, ponownie został pozbawiony posiłków w refektarzu i prawa wstępu do kapitularza ${ }^{164}$. Podobnie został ukarany i jego brat Feliks, biorący udział w zaczepkach i zniewagach aranżowanych przez Jana. Obaj bracia obrzucali Benedykta Izdbieńskiego nieprzystojnymi słowami ${ }^{165}$. Sprawa Naropińskiego przeniosła się na forum rzymskie. Dnia 4 X 1541 r. kapituła wyznaczyła swego prokuratora Stanisława Konarskiego ${ }^{166}$, który miał jechać do Stolicy Apostolskiej i tam doglądać procesu z Naropińskim, jak i innych spraw kapitulnych ${ }^{167}$. Oprócz Konarskiego, działali w Rzymie na stałe wyznaczeni i zamieszkali tam pełnomocnicy: Jan Chrzciciel de Rochetis, Włoch; Stanisław z Rzeczycy, kanonik włocławski ${ }^{168}$; Jan Wityński, kanonik płocki ${ }^{169}$ i Leonard Herman z Poznania, kanonik średzki ${ }^{170}$. Naropiński ze swej strony też wyznaczył pełnomocników: Jana Wysockiego, kanonika włocławskiego i kruszwickiego; Jana Dziaduskiego, biskupa margarytańskiego ${ }^{171}$; Macieja

\footnotetext{
160 Cap. Crac. 3, k. 309.

161 Tamże, 'k. 263, 267, 268, 283', 285.

162 Tamże, k. $323-324,390^{\prime}$.

${ }_{163}$ Tamże, k. 328, 331'.

164 Tamże, k. $329-329^{\prime}$.

165 Tamże, k. 304, 329'-330.
}

166 Stanisław Konarski, h. Abdank, jesienią 1546 r. napadnięty na ul. Mikołajskiej $\mathrm{W}$ Krakowie, zmarl $\mathrm{z}$ otrzymanych ran 3 XII 1546. Jego brat Jan, prepozyt kolegiaty św. Michała na Wawelu, kanonik krakowski, spłacał długi nieboszczyka (Cap. Crac. 4, k. 192; Łętowski, Prałaci III, s. 161).

167 Cap. Crac. 3, k. 338, 339-339', 340, 342.

168 Stanisław z Rzeczycy, doktor obojga praw (um. 1548), h. Łodzia, nobilitowany przez Piotra Tomickiego, penitencjarz apostolski dla Polaków w Rzymie (Wp źródł. II, nr 182, s. 148).

169 Jan Wityński, kanonik krakowski od r. 1547 (Cap. Crac. 4, k. 213'), kanonik płocki, był prokuratorem rzymskim. Zmarł w Płocku, w kwietniu 1559 r. (Cap. Crac. 5, k. 344, 348').

170 Cap. Crac. 3 , k. $349^{\prime}, 366$.

171 Jan Dziaduski, h. Jelita, sufragan włocławski z tytułem biskupa margaryteńskiego (od r. 1549), później biskup kamieniecki, chełmski i przemyski. Pasterz gorliwy, bardzo ceniony przez St. Hozjusza. Umarł 28 VII 1559 (J. Kwolek, [w:] PSB 6, s. 71-73). 
Łąckiego, archidiakona pomorskiego, kanonika gnieźnieńskiego; Stanisława Dąbrowskiego, doktora obojga praw, archidiakona kurzelowskiego i kanonika kruszwickiego ${ }^{172}$. Jak widać z powyższych danych, sprawa Naropińskiego nabrała rozgłosu i naraziła kapitułę na znaczne koszta ${ }^{173}$ utrzymania pełnomocników w Rzymie. Gamrat i kapituła krakowska postanowili nie dopuścić Naropińskiego do zajęcia stanowiska opiekuna szkoły zamkowej.

Hozjusza w tym czasie w Krakowie nie było, towarzyszył dworowi królewskiemu w Wilnie. Powrócił w czerwcu 1542 r. Na zebraniu kapituły pokazał się pierwszy raz, po długiej nieobecności od czasu swej instalacji kanoniczej, dopiero dnia 23 VI 1542 r. ${ }^{174} \mathrm{Z}$ opowiadań kolegów poznał przebieg sprawy Naropińskiego. Z ulgą przyjął do wiadomości, że zakończyła się ona kompromisem dzięki pośrednictwu Gamrata; 21 VII 1542 r. została podpisana umowa ${ }^{175}$, mocą której Andrzej Czarnkowski ${ }^{176}$, kanonik poznański i sekretarz królewski, miał objąć prałaturę kustodii ${ }^{177}$, a Janowi Naropińskiemu ${ }^{178}$ przyznano scholasterię.

Pod nieobecność Hozjusza w katedrze miał miejsce jeszcze jeden przykry incydent, mianowicie wielki i’ zasłużony prałat Jerzy Myszkowski ${ }^{179}$, archidiakon krakowski, w dniu 25 II 1542 r. na ambonie nazwał swego ordynariusza i prymasa Piotra Gamrata mianem simoniacus ${ }^{180}$, czyli publicznie oskarżył go o symonię. Można przypuszczać, że Myszkowski uczynił to rozgoryczony załamaniem się swej kariery po śmierci Jana Latalskiego. Myszkowski miał powiedzieć z ambony, że biskupem w. Polsce zostaje się nie z łaski Bożej, lecz za pieniądze dawane panującym. Trąciło to płytką demagogią. Prawdą jednak było, że panujący z okazji nominacji biskupich pobierali pewne taksy od kapituły (mimo że nie wskazywała ona kandydata na biskupa) i traktowali to jako daninę na cele publiczne. Tego zdania był również Stanisław Hozjusz, który po śmierci Piotra Gamrata pożyczył kapitule 150 dukatów na podarunek dla króla i królowej z okazji omawiania terminu przyszłej elekcji biskupiej na stolicę krakowską ${ }^{181}$. Wystąpienie archidiakona Myszkowskiego nie tylko nie zostało ukarane przez kapitułę, chociaż tego żądał biskup Gamrat przez swego kanclerza B. Gądkowskiego, lecz niedłu-

172 Cap. Crac. 3 , k. $344^{\prime}-345$.

${ }^{173}$ Tamże, k. $334^{\prime}, 337,339-339^{\prime}, 340,341,342,347,334^{\prime}-335$.

174 Tamże, k. 377'.

175 Tamże, k. 381-382.

176 Tamże, k. $380^{\prime}$ i 381 .

177 Tamże, k. 383 (11 VIII 1542).

178 Jan Naropiński zmarł w cenzurach kościelnych, zwolniony od nich dopiero

po śmierci 24 IX 1546 r. (Cap. Crac. 4, k. 177'; Korytk. Prataci III, s. 90).

179 Ep Crac. 22, k. 195'-196.

180 Cap. Crac. 3 , k. $357-357^{\prime}$.

181 Dnia 28 IX 1545 (Cap. Crac. 4, k. 98). 
go potem dnia 26 V 1542 r. kapituła wyznaczyła Myszkowskiego do przemawiania wobec króla ${ }^{182}$.

Rozgoryczenie wśród starszego pokolenia prałatów udzieliło się również Stanisławowi Borkowi. Chociaż wspólnie przebywał z Samuelem Maciejowskim i Stanisławem Hozjuszem na dworze Piotra Tomickiego, to jednak - gdy Maciejowski został biskupem krakowskim - nigdy nie odwiedził swego dawnego kolegi. Gdy Hozjusz otrzymał od kapituły dom retro collegium Canonistarum, Borek nie poparł go. Za Hozjuszem opowiedzieli się: Samuel Maciejowski, Andrzej Zebrzydowski, Stanisław Przeborowski i koledzy ze studiów padewskich Maciej Drzewicki ${ }^{183}$ i Jan Drohojowski ${ }^{184}$.

Niedługo po przyjeździe do Krakowa Hozjusz był świadkiem awantury w katedrze; podczas sumy Jan Drzewicki obrzucił obelżywymi słowami Stanisława Przeborowskiego za to, że ubrał jego kapę. Za to zgorszenie dane zgromadzonym w katedrze Drzewicki został pozbawiony wspólnych posiłków w refektarzu i prawa wstępu do kapitularza przez trzy miesiące ${ }^{185}$.

Dnia 24 II 1547 r. Hozjusz objął przy ul. Kanoniczej dom nr 18. Naprzeciw tego domu, z ukosa położona kamienica pod nr 17 była kurią biskupa Gamrata. Po jego śmierci Maciejowski, mając wspaniale odbudowany własnym kosztem dom ,św. Grzegorza”, zostawszy biskupem krakowskim nie reflektował na tę kurię, w której dawniej mieszkał biskup Tomicki i Gamrat, lecz pozostał u siebie. Dawny dom Gamrata optowali i otrzymali go dwaj kanonicy in solidum: Maciej Zieleński i Zbigniew Ziółkowski ${ }^{186}$. Zgoda między nimi trwała niedługo, więc dla zapewnienia pokoju kapituła wyznaczyła komisję w celu podzielenia domu ${ }^{187}$. Między tymi kanonikami wybuchały spory i awantury słyszane na ulicach i zakłócały spokój w pobliskim mieszkaniu Hozjusza. W lecie 1548 r. te kłótnie się nasiliły, przybierając postać skandalu. Kapituła 9 XI 1548 r. obu konfratrów pozbawiła domu, odmówiła im codziennych posiłków w refektarzu i zabroniła wstępu do kapitularza ${ }^{188}$. Obaj kanonicy upokorzyli się, wnieśli prośbę do kapituły o darowanie im win. Po długich naradach 6 II 1549 r. kapituła pozostawiła w pogamratowym domu tylko Macieja Zieleńskiego ${ }^{189}$, a gdy zmarł w r. 1550 Zygmunt So-

182 Cap. Crac. 3, 1. 373'.

${ }_{183}$ T. Glemma, Drzewicki Maciej, h. Ciołek, kanonilk krakowski, prepozyt włocławski, sekretarz kólewski, umarł w Rzymie w czasie pielgrzygmki jubileuszowej

11 XII 1575), [w:] PSB 5, s. 412.

184 Cap. Crac. 3, k. 249-250.

185 Tamże, k. 379-379', 386.

${ }^{186}$ Zbigniew Ziółkowski, h. Korczak, przyjęty został do kapituły krakowskiej

24 XI 1537 (Cap. Crac. 7, k. 326'-327).

${ }_{187}$ Cap. Crac. 4 , k. $175,262-262$ '.

188 Tamże, k. $269-270,290$.

189 Tamże, k. 296'-297. 
bek, jego dom przydzielono kanonikowi Zbigniewowi Ziółkowskiemu ${ }^{190}$. Gdy Hozjusz - jako nominat chełmiński - wyjeżdżał za granicę w poselstwie od króla polskiego do cesarza, w otoczeniu jego kamienicy zapanował spokój.

Obok krzykliwych napadów słownych na członków kapituły, praktykowanych przez niektórych konfratrów, zdarzały się również najazdy zbrojne. Pierwszą wyprawę zbrojną na majątek kapitulny zorganizował Jan Konarski, prepozyt kolegiaty św. Michała. Zaczęło się od tego, że 29 IV 1545 r. Konarski, posiadający prestimonium bieżanowskie, zamienił się B. Izdbieńskim na podobne beneficjum w Dziekanowicach koło Bosutowa ${ }^{191}$. Po niedługim czasie Konarski zauważył, że źle wyszedł na zamianie, bo beneficjum w Bieżanowie było o wiele lepsze; wówczas zażądał od Izdbieńskiego anulowania zamiany. Gdy do tego nie doszło, Konarski wziąwszy 40 jeźdźców oraz 20 pieszych w noc świętojańską najechał na Bieżanów i zajął go wraz z inwentarzem ${ }^{192}$. Na szeregu zebrań kapitulnych, na których bywał Hozjusz, omawiano sprawę tego zajazdu, lecz wobec śmierci Piotra Gamrata i nominacji B. Izdbieńskiego na biskupa kamienieckiego, dyskusji zaniechano ${ }^{193}$.

Tenże sam Konarski dokonał drugiego najazdu zbrojnego w r. 1548. Od wiosny tegoż roku, jako zarządca dóbr Toń pod Krakowem, prowadził kłótnię z Wojciechem Kijowskim, posiadaczem prebendy kościoła św. Jerzego na Wawelu w Bronowicach Niemieckich (dziś Wielkich) w sprawie granic tych majątków. Konarski zarzucał Kijowskiemu nieludzkość (bestialitas) oraz scholastycyzm (scholasticitas), co w mniemaniu humanisty uchodziło za wielką obelgę, i zorganizował najazd zbrojny ${ }^{194}$. Dnia 20 VII 1548 r. Jan z Ocieszyna, kasztelan biecki, podkomorzy ziemi krakowskiej, oraz Marcjan Chełmski, komornik tejże ziemi, wymierzyli granice obu posiadłości ${ }^{195}$; w ten sposób spór został zakończony.

Zaraz po wyjeździe Hozjusza za granicę ul. Kanonicza znowu napełniła się zgiełkiem i łomotem. Oddział zorganizowany przez rodzinę Czarnkowskich włamał się 24 I 1550 r. do domu Jakuba Uchańskiego, naprzeciw kościółka św. Marii Magdaleny (ul. Kanonicza 9) ${ }^{196}$. Scholastyk, podobnie jak w roku ubiegłym po morderstwie żaka w szkole Wszystkich Świętych, powiedział, że stało się to bez jego wiedzy.

190 Tamże, k. 393.

191 Tamże, k. 72.

192 Tamże, k. 81-82.

193 Prymas Piotr Gamrat zmarl 27 VIII 1545, a niedługo potem (dnia 23 X 1545) Benedykt Izdbieński, kantor krakowski, został wezwany do króla w sprawie nominacji na biskupstwo kamienieckie; zatwierdżenie apostolskie otrzymał 19 II 1546 (Cap. Crac. 4, k. 114).

194 Cap. Crac. 4, k. 256', (16 V 1548).

195 Tamże, k. 269.

196 Tamże, k. $348^{\prime}-349$. 
Inną formą najazdów na majątki kapitulne przez członków kapituły, synów magnackich dysponujących oddziałami zbrojnymi, były wyprawy do lasów kapitulnych i dowolne wycinanie drzew w tych lasach. W kwietniu 1550 r. (kiedy Hozjusz zrzekł się kamienicy nnr 18 i prestymonium w Łososkowicach) domownicy Czarnkowskiego urządzili napad na las w Goszczy i wycięte drzewa zwozili do Mistrzejowic, majątku scholastyka. Gajowego wypędzono i zapowiedziano mu, by jeśli chce wrócić do nich, przyniósł worek na swoje kości. Dumny magnat z Kórnika lekceważył protesty kapituły, która przesadnie oskarżała go o wycięcie lasu. Kapitulny las gostecki do dziś istnieje, siedmiu ludzi rąbiących drzewo zdołało zapewne wyciąc niewielki tam odcinek zielonej dąbrowy. Tak samo i kasztelanic sandomierski, syn ochmistrza królowej Bony Stanisław Wolski, kustosz krakowski, zorganizował również samowolny wyrąb drzewa w Węgrzcach ${ }^{197}$.

Tych kilku dygnitarzy; dopuszczających się gwałtów i ekscesów na terenie kapituły krakowskiej, było niewielkim wyjątkiem wśród 70 osobowej grupy członków kongregacji za czasów Hozjusza, stanowiąc tylko rysę na ogólnym obrazie krakowskiego zgromadzenia chórowego. Niemniej ich wystąpienia są bardzo symptomatyczne i świadczą o upadku autorytetu biskupiego (Piotra Gamrata i Samuela Maciejowskiego), do czego przyczyniło się zawładnięcie przez parę królewską prawem nominacji na ważniejsze prałatury w polskich kapitułach, a także nepotyzm i protekcjonim biskupów przyjmujących do kapituły swych krewnych i synów zaprzyjaźnionych rodzin szlacheckich. To nie stanowiło jednak reguły, bo biskupi rozumieli też zapotrzebowanie $\mathrm{w}$ kapitule na świat‘ łych i gorliwych kapłanów.

\section{KAPITUモA KRAKOWSKA W CZASACH HOZJUSZA JAKO STROŻ ORTODOKSJI KATOLICKIEJ}

Hozjusz wszedł do kapituły krakowskiej w czasie, kiedy cały Kościół katolicki w Polsce przeżywał wielki kryzys. Powszechne wołanie o reformę w Kościele, zwłaszcza o pogłębienie życia religijnego, o przemianę niezgodnych z duchem chrześcijańskiego ubóstwa kościelnych urządzeń gospodarczych, o oczyszczenie przestarzałych form kultowych, a przede wszystkim o podniesienie poziomu moralnego większości zupełnie zlaicyzowanego duchowieństwa, przerodziły się w reformację deformującą dotychczasową doktrynę Kościoła i rozbijającą na różne obozy jednolitą dotychczas Rzeczpospolitą chrześcijańską na Zachodzie. W czasach Hozjusza' zwolennicy reformacji zaczęli coraz liczniej pojawiać się na tere-

197 Tami̇e, k. 358. 
nie diecezji krakowskiej, a w połowie XVI w. poważnie zagrozili lokalnemu Kościołowi krakowskiemu.

Do walki z nowinkami religijnymi wystąpili, choć nie zawsze gorliwie, biskupi, synody, kapituły katedralne, a czasem też i sejmy krajowe. Kościół nie umiał jeszcze w tym czasie wskazać pozytywnego sposobu i wytyczyć odpowiedniej drogi do obrony starożytnej wiary katolickiej, którą wyznawał naród polski przez sześć wieków. Obrona ta mogła polegać na głoszeniu odpowiednich kazań i uświadamianiu społeczeństwa, utwierdzaniu go w wierze; niestety kaznodzieje nie starali się zapobiegać szerzeniu niewłaściwych poglądów odnośnie ustroju kościelnego i dogmatów katolickich, nieraz stosowali szeroką krytykę stosunków w Kościele i przez to bezwiednie torowali drogę dla nowinek religijnych. Nie podjęto druku książek katolickich w języku polskim, dostępnych dla szerokich warstw społecznych, nie reformowano złych obyczajów duchowieństwa i ludzi świeckich. Kościół nie reagował na rozrzutność bogatych beneficjatów i na wystawne życie hierarchów. Nie prowadzono akcji charytatywnej, której bogate duchowieństwo nie doceniało i nie przeznaczało na nią pieniędzy. Kościół posługiwał się ustaloną od wieków metodą inkwizycji, wzywał podejrzanych przed swój sąd i karał ich.

Niedługo po wejściu Hozjusza do kapituły krakowskiej zapadła $20 \mathrm{~V}$ 1540 r. uchwała, na podstawie której Paweł Krassowski, wikariusz generalny i oficjał krakowski, oraz Feliks Naropiński i dwóch doktorów z wydziału teologii Uniwersytetu Krakowskiego zostało upoważnionych do rewidowania ksiąg w księgarniach, by stwierdzić czy nie ma w nich treści innowierczych ${ }^{198}$. Gdy zbliżała się jesienna kapituła generalna 1541 r. kanonicy zażądali ożywienia w diecezji działalności inkwizytorskiej ${ }^{199}$. Wprawdzie po śmierci inkwizytora z czasów biskupa Piotra Tomickiego Marcina z Olkusza, doktora św. teologii, prepozyta kościoła św. Mikołaja w Krakowie ${ }^{200}$, ustanowiono nowego inkwizytora Jana z Kazimierza, magistra św. teologii, przeora karmelitów na Piasku, lecz ten sprawował swój urząd bez żadnego wynagrodzenia niezbyt gorliwie. Celem zdopingowania go ustanowiono odtąd dla inkwizytora pensję w wysokości 40 grzywien rocznie, wypłacaną mu z dochodów włodarstwa krakowskiego. Przy tej okazji określono jeszcze raz prawa i obowiązki inkwizytora. Urząd ten był dożywotni. Inkwizytor miał prawo upominać błądzących $\mathrm{w}$ wierze, a uporczywie pozostających $\mathrm{w}$ błędzie wykluczać $z$ Kościoła, nawet mógł wzywać przeciwko opornym pomocy ramienia świeckiego (brachium saeculare) ${ }^{201}$.

\footnotetext{
198 Cap. Crac. 3, k. 258.

199 Tamże k. 334.

200 Ep. Crac. 2, k. 113'.

201 Ep. Crac. 23, k. 54-56.
} 
Kapituła krakowska zazwyczaj wysyłała swoich delegatów na sejmy koronne. Dnia 25 II 1542 r. wybrała Bartłomieja Gądkowskiego, Mikołaja Miłkowskiego i Macieja Drzewickiego ${ }^{202}$ na sejm do Piotrkowa w dniu 5 marca. Równocześnie Piotr Gamrat, który dzięki pośrednictwu królowej Bony kumulował biskupstwo krakowskie i arcybiskupstwo gnieźnieńskie, zaczął się pilnie krzątać około zwołania swego pierwszego synodu prowincjonalnego w Piotrkowie. Dnia 11 VIII 1542 r. kanclerz Gamrata Bartłomiej Gądkowski, przedłożył kapitule rozporządzenie biskupa, zapowiadające synod i pewne jego czynności wstępnie ${ }^{203}$. Kapituła 3 X 1542 r. wybrała swych delegatów: dziekana Stanisława Borka i kantora Benedykta Izdbieńskiego, którzy mieli jechać do Piotrkowa na dzień $17 \mathrm{X}$. Otrzymali oni jeszcze dodatkowe poruczenie, żeby wracając z synodu dokonali wizytacji majątku kapitulnego w Pabianicach, gdzie na nich miał oczekiwać Filip Padniewski ${ }^{204}$, przewidziany na trzeciego wizytatora tych dóbr. Biskup Piotr Gamrat przed synodem prowincjonalnym zamierzał odbyć synod diecezjalny w Krakowie ${ }^{205}$.

Te dwa synody zarządzone na początku rządów Gamrata świadczą niewątpliwie o gorliwości biskupa dwóch największych i najbogatszych diecezji, a uchwały powzięte w Piotrkowie, ułożone przez Gamrata (przy pomocy sekretarza Marcina Kromera) świadczą ò wielkiej jego mądrości. Prymas zajął się przede wszystkim poprawą obyczajów duchowieństwa. Zwrócił przy tym uwagę na potrzebę podniesienia poziomu kaznodziejstwa. Wykazał zainteresowanie niższym duchowieństwem i szkolnictwem parafialnym, ponadto silny nacisk położył na potrzebę zajęcia się Akademią Krakowską. Na pięć najlepiej uposażonych biskupstw nałożył obowiązek składania stałej dotacji rocznej na rzecz Uniwersytetu. Sam też zobowiązał się wpłacać rocznie na ten cel 100 dukatów. Naradzano się na synodzie, jak uchronić Kościół polski przed wpływami reformacji. Powyższe uchwały miały być odpowiedzią na to, a ich dokładne wykonanie dawało rękojmię uodpornienia społeczeństwa polskiego przed nowinkami religijnymi. By uniknąć zatargów Kościoła ze świecką szlachtą, Gamrat polecił ściśle rozgraniczyć sądownictwo kościelne od świeckiego ${ }^{206}$. Dodano dwa rozdziały przeciwko od dawna istniejącym wyznaniom re-

202 Cap. Crac. 3, 1. 356.

203 Tamże, k. 383.

204 Tamże, k. 389.

205 Tamże, k. 230'. Zapis z dnia 9 X 1542.

${ }^{206}$ Mimo, że minęla epoka „Bony trucicielki“, po ukazaniu się dzieła W. Pociechy o królowej Bonie, Gamrat w dalszym ciągu nie ma dobrej prasy, owszem nawet dobre jego poczynania są kamieniem obrazy dla wielu historyków. Człowiek wysokiej kultury humanistycznej, wymowny, oddany dynastii i doradca królewski, uprzejmy i gościnny, łagodny i umiejący godzić zwaśnionych, wielkiego rozumu, szczerze przywiązany do Kościoła - miał tę wadę, że swą hojność posuwał do rozrzutności (Ep. Crac. 21, k. 465-467) i tę słabość, że nie umial wytoczyć bezwzględnej walki swym przeciwnikom i oszczercom. 
ligijnym: o zakazie budowy cerkwi prawosławnych i o wydaleniu żydów z Krakowa ${ }^{207}$. W tym czasie nurtowały kapitułę krakowską bardzo silne nastroje antyżydowskie, które miały widoczny wpływ na redakcję ostatniej uchwały synodu. Pod presją kapituły - jak się zdaje - doszło również do wyroku skazującego Katarzynę Malcherową na spalenie na stosie (19 IV 1539) za sprzyjanie religii żydowskiej ${ }^{208}$.

W ciągu roku 1542 kapituła krakowska była zajęta sprawą Jana Easkiego, syna Jarosława, który w r. 1540 ob rumorem matrimonii contracti został pozbawiony wszystkich swoich beneficjów kościelnych. Doszła bowiem do kapituły wiadomość, że w Wittenberdze wyrzekł się on wiary katolickiej i w Lowanium poślubił żonę. Wieść o tym dnia 20 VIII 1540 r. doszła do Piotra Gamrata, który wtedy przebywał w Bodzentynie. Kanclerz kurii Bartłomiej Gądkowski natychmiast poprosił biskupa o prowizję na kanonię marchocką, którą dotychczas posiadał Łaski, ale nie został zaaprobowany przez kapitułę. Bartłomiej Niszczycki, kanclerz płocki 18 listopada $1540 \mathrm{r}$. poprosił także o prowizję na tę prebendę ${ }^{209}$. Jednakże Gądkowski nie zrezygnował ze swoich pretensji do prebendy marchockiej na rzecz Niszczyckiego. Dopiero 2 II 1541 r. doszło między nimi do ugody. Do kanonii marchockiej w katedrze krakowskiej wysuwał żądanie instalacji także Maciej Zieleński, pleban w Opatowcu, zaufany rodziny Łaskich, który już w r. 1536 został przyjęty przez Jana, syna Jarosława, na koadiutora tejże prebendy. Wprawdzie 5 VIII $1541 \mathrm{r}$. Maciej Zieleński wymusił na kapitule krakowskiej przyjęcie go na prebendę marchocką vigore coadiutoriae, ale pozostała wątpliwość, czy jego koadiutoria jest ważna ze względu na to, że jego patron utracił kanonię i tym samym nie mógł już mieć koadiutora; i prawdopodobnie Zieleński nie był dopuszczony do dochodów z tej niepewnie zdobytej kanonii. Zieleński porozumiał się z Łaskimi, którzy z początkiem grudnia $1541 \mathrm{r}$. mieli się spotkać ze swoim bratem Janem we Wrocławiu. Po wspólnej naradzie we Wrocławiu Łascy ustalili, że Jan Łaski - mimo ożenku będzie się starał o przywrócenie mu kanonii krakowskiej ${ }^{210}$. Jan Łaski wstąpiwszy do Krakowa - wyjechał do Kieżmarku, aby odwiedzić chorego brata Hieronima. Wkrótce zwrócił się do biskupa Piotra Gamrata o zwrot kanonii marchockiej w Krakowie, zgłaszając gotowość złożenia

207 Cap. Crac. 3, k. 238', 239.

208 Wp źródł. II, nr 146, s. 120-121.

209 Ep. Crac. 22, k. 31, 47; Cap. Crac. 3, 1. 283-283'. Sprawa Easkiego interesowała Hozjusza, albowiem wspomina o niej w listach. Dnia 18 XI 1541 pisał z Wilna do Dantyszka: De d. Joanne a Lasco allatum est fuisse eum Cracoviae, sed clam - nunc in Kiersmarck (castrum Hieronymi Easki in Scepusio) profectum ad visendum fratrem valetudinarium (Hos. eplae I, 100, s. 119). Wspomina Hozjusz, że Łaski podpisuje się: Joannes a Lasco, nuper multis titulis insignis, nunc nudus nudi Jesu crucifixi servus (Hos. eplae I, nr 98, 5 XI 1541, s. 117).

${ }^{210}$ Jan Easki ostatni raz został wymieniony jako obecny w kapitularzu na kapitule majowej 1534 r. (Cap. Crac. 3, k. 106'). 
katolickiego wyznania wiary i przysięgi wierności Kościołowi ${ }^{211}$. Sprzyjający Easkim Gamrat - w nadziei związania z Kościołem katolickim znakomitego prałata - przyjął od niego dnia 6 lutego 1542 r. protest przeciw plotkom, jakie o nim szerzono i wymagane deklaracje, $\mathrm{m}$. in. obietnice osiedlenia się w Krakowie, następnie dnia 3 III 1542 r. przywrócił mu faktycznie jeszcze nie obsadzoną kanonię marchocką i dom kapitulny z daru Jana Dębińskiego, usytuowany przy bramie kazimierskiej nad starym korytem Rudawy ${ }^{212}$. Przy tej okazji Łaski, jako rzeczywisty kanonik krakowski, ratyfikował koadiutorię Macieja Zieleńskiego przy swej prebendzie.

Cała ta sprawa Jana Łaskiego - wyreżyserowana i połączona z kłamliwymi oświadczeniami oraz krzywoprzysięstwem - miała na celu ułatwienie wiernemu słudze rodu Łaskich Maciejowi Zieleńskiemu wejście do stall kapituły katedralnej krakowskiej ${ }^{213}$. Po tej fikcyjnej konwersji Łaski wyjechał do Emden, gdzie pełnił obowiązki superintendenta zboru i stamtąd przysłał upoważnienie dla kanonika krakowskiego Stanisława Przeborowskiego, aby $\mathrm{w}$ jego imieniu zrezygnował $\mathrm{z}$ kanonii krakowskiej ${ }^{214}$. Przeborowski dokonał tego 16 III 1543 r., a Maciej Zieleński, który w międzyczasie zarządzał domem Łaskiego przy bramie kazimierskiej ${ }^{215}$, został jako rzeczywisty koadiutor Łaskiego bez żadnej przeszkody wprowadzony do kapituły krakowskiej na jego miejsce.

Gdy kapituła poczęła rozpatrywać sprawę apostaty Łaskiego, Hozjusza jeszcze nie było w Krakowie. Pojawił się dopiero 28 VII 1542 r. $^{216}$ Z Łaskim miał jednak okazję spotkać się, ale tylko na płaszczyźnie działalności pisarskiej ${ }^{217}$.

Osobiście Hozjusz był zaangażowany w sprawę Leonarda Słończewskiego, kaznodziei kościoła Mariackiego. Dnia 23 V 1544 r. kapituła otrzymała wiadomość, że poprzedniego dnia na ambonie tegoż kościoła w Krakowie kaznodzieja doktor Leonard wystąpił publicznie przeciw władzy papieskiej. Kanonicy podjęli uchwałę, by tę sprawę przekazać inkwizytorowi haereticae pravitatis ${ }^{218}$; urząd ten pełnił wówczas profesor Jan z Kazimierza. Nie wiadomo, jaki przebieg miał proces doktora Leonarda

211 Ep. Crac. 19, k. 55; Cap. Crac. 3, k. 148-148', 319-319'.

212 Ep. Crac. 3, k. 351'-352; 19, k. 379'-381; Cap. Crac. 3, k. 359'-360.

213 Jan Łaski osobiście stwierdził, że pogłoski, które się o nim rozeszły, nie są prawdziwe, że chce wytrwać przy wyznaniu wiary złożonym 6 II 1542 przed Gamratem. Wprawdzie wyjedzie do Niemiec, ale tylko po to, by się zaopiekować dziećmi swego brata, ale powróci i pozostanie w ojczyźnie (Cap. Crac. $3, \mathrm{k}$. $360^{\prime}$, $361^{\prime}$.

214 Cap. Crac .3, k. 416-417.

215 Tamże, k. 359, 407.

216 Tamże, k. 380.

217 Jan Łaski wydrukował przeciw Hozjuszowi książkę: De oppresso verbo Dei. Odpowiedź swoją na nią Hozjusz dedykował Zygmuntowi Augustowi.

218 Cap. Crac. 4, k. 17. 
przed sądem inkwizycyjnym, faktem jednak było, że dalej pełnił on funkcję kaznodziei w kościele. Mariackim. Chyba wytłumaczył się dostatecznie, skoro Jakub z Kleparza, kanonik katedralny krakowski, profesor św. teologii, rezygnując dnia 21 VI 1544 r. z powodu słabego zdrowia z officium predykatury katedralnej, zaproponował na swego następcę doktora Leonarda ${ }^{219}$. Wkrótce został on kaznodzieją katedralnym. Sprawa obsadzenia stanowiska kaznodziei katedralnego weszła na obrady kapituły dnia 22 XI 1544 r. W kapitularzu razem z innymi kanonikami zasiadł Hozjusz. Wybór doktora Leonarda odbył się jednomyślnie. Słończewski przy tej okazji otrzymał pochwały jako vir eruditione insignis et exemplaritate conspicuus. Kaznodzieja wybrany przez kapitułę, według zwyczajów kapituły krakowskiej, powinien być zatwierdzony przez biskupa ordynariusza. Dnia 9 XII 1544 r. nadeszło do kapituły orzeczenie biskupa Gamrata aprobujące wybór Leonarda doktora teologii, prepozyta kościoła św. Jadwigi, należącego do kanoników Grobu Bożego, zwanych miechowitami ${ }^{220}$. Doktor Leonard rozpoczął swą pracę na ambonie katedralnej jako concionator ordinarius ecclesiae cathedralis Cracoviensis. Ponownie jednak zaniepokojenie kapituły wywołała wiadomość na początku lutego 1545 r., że Leonard w kościele NMP w Krakowie posunął się do inwektyw przeciw stanowi duchownemu, kwestionował kult NMPanny, podawał w wątpliwość niektóre ceremonie kościelne. Kapituła postanowiła rozpatrzyć sprawę tegoż kaznodziei. 6 II 1545 r. delegowała ze swego grona dwóch najlepszych teologów: doktora Stanisława Hozjusza i doktora Jakuba z Kleparza, aby oni w imieniu kapituły upomnieli kaznodzieję ${ }^{221}$. Rozmowa z doktorem Leonardem miała pozytywny skutek i doprowadziła do porozumienia. W tym czasie kaznodzieja Leonard wniósł do kapituły prośbę, by z racji pełnionego urzędu mógł otrzymać przydział chleba i śledzi. Obaj kanonicy wyznaczeni do prowadzenia śledztwa postarali się o pomyślne załatwienie tej petycji i osobiście powiadomili doktora Leonarda o przyznaniu mu wiktuałów, o które prosił ${ }^{222}$, wyrażając współczucie dla tegoż kaznodziei z powodu niedawno dokonanego na niego zbrojnego napadu ${ }^{223}$. Leonard Słończewski odznaczał się wieloma zaletami i mimo swej śmiałości w myśleniu teologicznym wzbudzał sympatię, dlatego też otrzymał od króla nominację na biskupa kamienieckiego ${ }^{224}$. Był gorliwym biskupem, rezydował w stolicy swej diecezji Kamieńcu i z powodu pięknych kazań był lubiany przez tamtejszą ludność ${ }^{225}$.

219 Tamże, k. 38'.

220 Tamże, k. 45,46 .

221 Tamże, k. 54'.

222 Tamże, k. 55.

223 Tamże, k. 54.

224 Zatwierdzony przze Stolicę Apostolską 20 VIII 1546 (HE III, 148).

225 Jak kaznodziejstwo wówczas nie dopisywało, świadczy o tym następujący 
Tymczasem prymas Piotr Gamrat myślał o zwołaniu drugiego z rzędu swego synodu prowincjonalnego i równolegle do niego synodu diecezji krakowskiej. Najpierw kapituła krakowska 1 X 1544 r. otrzymała od swego ordynariusza zapowiedź zwołania synodu diecezjalnego ${ }^{226}$; nazajutrz kapituła została poinformowana o zamiarze arcybiskupa zwołania na dzień 14 X 1544 r. synodu prowincjonalnego do Piotrkowa ${ }^{227}$. Ka- pituła zebrała się na posiedzeniu w piątek $6 \mathrm{X}$, aby przygotować instrukcje dla swoich delegatów do Piotrkowa. Instrukcje te przejrzeli: Piotr Porębski i Benedykt Izdbieński. Na delegatów wyznaczono Bartłomieja Gądkowskiego, kanclerźa Gamrata, i Benedykta Izdbieńskiego, wikariusza generalnego i zarządcę Pabianic. Ze względu na wizytację Pabianic, którą mieli przeprowadzić ci deputowani, dodano im jeszcze Mikołaja Miłkowskiego ${ }^{228}$. Po powrocie z Piotrkowa obaj delegaci złożyli przed kapitułą dnia 19 XII 1544 r. sprawozdanie z obrad synodalnych ${ }^{229}$. Uchwały synodu piotrkowskiego były $\mathrm{w}$ zasadzie powtórzeniem synodu $\mathrm{z} \mathrm{r}$. 1542. Na synodzie w r. 1544 chodziło przede wszystkim o usankcjonowanie i realizację tamtych uchwał, dlatego kapituła ustanowiła komisję, w skład której weszli obaj wspomniani wyżej delegaci na synod piotrkowski oraz dziekan kapituły Stanisław Borek. Komisja ta miała się zająć sprawą realizacji w diecezji krakowskiej uchwał ostatniego synodu prowincjonalnego ${ }^{230}$.

Biskup Gamrat był zaniepokojony rozszerzaniem się nowinek religijnych w diecezji krakowskiej i w samej kapitule. W tym celu na posiedzeniu kapituły 24 IV 1545 r. zarządził inkwizycję kanoników. Na zlecenie biskupa kapituła wybrała komisję w składzie: Stanisław Borek dziekan, Bartłomiej Gądkowski — archidiakon, dr Stanisław Hozjusz, prof. Jakub z Kleparza i prawnik Zygmunt ze Stężycy oraz sufragan biskup Erazm Ciołek ${ }^{231}$. Była to w kapitule grupa osób ciesząca się najlepszą opinią ze względu na nieskazitelność życia, wiedzę teologiczną, pobożność i przywiązanie do wiary. Hozjusz wraz z prałatami zaczął 27 IV przesłuchiwać członków kapituły w sprawie prawowierności. Erazm Ciołek wyłączył się od tej funkcji ${ }^{232}$. Badania inkwizytorów nasunęły pewne wątpliwości odnośnie do wiedzy teologicznej i stałości przekonań religijnych u niedawno wysuniętego na kamieniecką stolicę biskupią Jana Drohojowskiego ${ }^{283}$. Natomiast czując zagrożenie, złożył $19 \mathrm{~V} 1545$ przed

przykład. Dnia 18 V 1545 kapituła krakowska debatowała nad kazaniem Andrzeja Dąbrowskiego, które wywołało zgorszenie w katedrze (Cap. Crac. 4, k. 75).

228 Cap. Crac. 4 , k. 33.

227 Tamże, k. 34 .

228 Tamże.

229 Tamże, k. $46^{\prime}$.

${ }^{230}$ Tamże, k. $49^{\prime}$.

231 Tamże, k. $69^{\prime}$.

232 Tamże, k. 71.

233 Prowizję otrzymał dopiero 26 VIII 1545 (HE III, 148). 
kapitułą krakowską wyznanie wiary, które zostało wpisane do akt kip)ilulnych ${ }^{294}$. Uprzedzenie jednak co do jego wiedzy teologicznej i prawnwierności w kapitule pozostało i gdy Drohojowski otrzymał w r. 1551 nominacje na biskupstwo kujawskie, kapituła usiłowała przeszkodzić mu w otrzymaniu prowizji papieskiej na tę stolice, co się jej jednak nie udało. Drohojowski należał do najgorszych biskupów polskich tego czasu ${ }^{23 .}$.

Wkrótce śmiertelnie zachorował Piotr Gamrat i zmarł 27 VIII 1545 r. Kapituła zajęła się pogrzebem i wyborem nowego administratora die-cezji. Wybór padł na Andrzeja Czarnkowskiego, scholastyka krakowskiego. Za jego rządów kapituła zetknęła się z faktem, który wywołał wielkie poruszenie w Krakowie. Andrzej Garczki, inaczej zw. Wrzesieński, domownik kanclerza koronnego Tomasza Sobockiego, nie chciał się na łożu śmierci spowiadać a zażądał Komunii św. pod obiema postaciami. Napiętnowali to $\mathrm{z}$ ambon wybitni kaznodzieje krakowscy: doktor Leonard w katedrze i Łukasz z Orłowej (Aquilinus) w kościele N. P. Marii. Po śmierci Garczkiego zezwolenie na jego pogrzeb katolicki zależało od kapituły katedralnej, która konsultowała się u biskupów i doktorów. Wreszcie ustaliła się opinia mało prawdopodobna, że Wrzesieński popadł w obłę (phrenesis) i to dało podstawę do zezwolenia na skromny pogrzeb na cmentarzu katolickim, z wykluczeniem jednakże wszelkiej pompy ${ }^{236}$.

Fakt ten i wiele innych następnych wskazują, że pełne nasilenie propagandy protestanckiej rozpoczęło się w Krakowie dopiero po śmierci Gamrata, a na szeroką skalę rozwijało się za rządów biskupa Maciejowskiego. Odtąd miały miejsce tajne schadzki intelektualistów, ciekawych nowinek religijnych, na które uczęszczali także niektórzy kanonicy krakowscy. Zaniepokojony tym nowy biskup Maciejowski, w krótkim czasie po objęciu stolicy krakowskiej, przybył w dniu 4 VI 1546 r. na zebranie kapituły i wyraził swe obawy oraz podejrzenia nawet w stosunku do członków samej kapituły i zarządził badania inkwizycyjne. Wybrano wówczas nowe grono inkwizytorów: Stanisława Borka - dziekana, Jana Przerębskiego - nowego kanclerza kurii, Stanisława Hozjusza i Jakuba z Kleparza profesora ${ }^{237}$. Prócz tych delegatów, którzy mieli badać wy łącznie członków kapituły, na terenie diecezji krakowskiej działał Jan z Kazimierza, profesor teologii, przeor karmelitów na Piasku, jako inquisitor haereticae pravitatis. Zastanawiające, że $\mathrm{w}$ przeciwieństwie do zmarłego Gamrata, Samuel Maciejowski wcale się działalnością tego inkwizytora nie interesował; w ciągu całych rządów tegoż biskupa o aktywności Jana z Kazimierza wiemy tylko tyle, że zanosił do kapituły

234 Cap. Crac. 4 , k. $76^{\prime}-77$.

23.5 Por. S. Kot, Drohojowski Jan, [w:] PSB 5, s. 380-381.

236 Cap. Crac. 4 , k. $126^{\prime}-127$.

237 Tamże, k. $159-160$. 
krakowskiej zażalenia, iż włodarz biskupi nie wypłaca mu rocznej pensji 40 grzywien, ustalonej jeszcze za Piotra Gamrata ${ }^{238}$. Rola inkwizytorów w stylu średniowiecznym wobec nowych zadań i niebezpieczeństw Kościoła podupadła, całą defensywę musiała przejąć na siebie sama hierarchia. Nie zapomniała o tym kapituła krakowska, rozumiała ona potrzebe wyjaśniania prawd nauki katolickiej i dlatego wybrała Hozjusza do głoszenia w katedrze egzort na ten temat ${ }^{239}$.

Samuel Maciejowski objął rządy w diecezji krakowskiej w początkach reformy trydenckiej ${ }^{240}$. Kapituła krakowska była zaniepokojona, że z Polski nie posłano żadnego delegata na sobór do Trydentu. W październiku 1546 r. wybrała jako ewentualnego kandydata na sobór Stanisława IIozjusza ${ }^{241}$. Za rządów biskupich Samuela Maciejowskiego w Krakowie bardzo wzrosła sława Hozjusza jako pierwszego teologa w stolicy. Było to powodem, że zebrana dnia 21 VII $1547 \mathrm{r}^{242}$ kapituła, ulegając pewnie i życzeniu Maciejowskiego, wybrała jako delegata na synod prowincjonalny Hozjusza, który po raz pierwszy z jej ramienia miał wziąc udział w tego rodzaju zebraniu, gdzie uczestnikom ujawnił głẹbiẹ swego umysłu. Równocześnie biskup S. Maciejowski zamierzał zwołać synod diecezjalny, o czym powiadomił kapitułę dnia 12 VIII 1547 r. ${ }^{243}$.

Synod prowincjonalny gnieźnieński, równoległy do Soboru Trydenckiego, został zwołany przez prymasa Mikołaja Dzierzgowskiego na dzień 15 IX 1547 r., pierwotnie do Piotrkowa, lecz w skutek zarazy został przeniesiony do Łęczycy. Z powodu choroby prymasa przewodniczył na nim biskup krakowski Samuel Maciejowski. Według pisma Dzierzgowskiego skierowanego do uczestników synodu, zebrani mieli się zająć obroną Kościoła katolickiego w Polsce przed herezją, do czego walnie miała dopomóc poprawa wykształcenia teologicznego i obyczajów duchowieństwa. Dzierzgowski zwrócił siẹ też do członków synodu, aby ustalili, w jaki sposób Kościól polski, zwłaszcza jego duchowieństwo, może przyczynić siẹ swą pomocą do oddalenia niebezpieczeństwa tureckiego. Ponadto prymas polecił zastanowić się nad wyborem delegatów na Sobór Trydencki. Biskupowi wileńskiemu zlecono, by skłonił króla Zygmunta Augusta do usunięcia dworskiego kaznodziei Wawrzyńca Discordi, który

238 Tamże, k. 155', 198, 304, 304'.

239 Tamże, k. 221 (22 IV 1547).

240 Pawel III zwołał sobór trydencki bullą "Laetare Jerusalem" z dnia 19 XI 1544, a dnia 13 XII 1545 sobór został otwarty uroczystym nabożeństwem w katedrze San Vigilio w Trydencie.

$2: 11$ Cap. Crac. 4, k. 189-189'.

242 'Tamże, k. 235-235'.

243 'Tamze, k. 236'.

$2+4$ Acta historica res gestas Poloniae illustrantia, t. I, Kraków 1878, s. 446 
z ambon wileńskich głosił błędne nauki ${ }^{244}$. Znamienną było rzeczą, że synod poparł stanowisko cezariańskie, protestując przeciw przeniesieniu soboru z Trydentu do Bolonii, gdzie się odbyły dwie bezowocne sesje w latach $1547-1548{ }^{245}$. Synod nie spełnił wszystkich nadziei w nim pokładanych. Nie dokonał wyboru delegatów na Sobór Powszechny. Nie mógł wyegzekwować swego zlecenia, by z otoczenia bîskupów zostali usunięci kapłani, którzy prowadzili gorszący tryb życia. Nie było to rzeczą łatwą, zwłaszcza gdy dworzanie biskupów wywodzili się z magnackich rodów, mających wielkie znaczenie w państwie. Np. zaprzyjaźniony z biskupem Samuelem Maciejowskim scholastyk krakowski Andrzej Czarnkowski w ogóle nie odprawiał mszy św., a mimo to uganiał się za zdobyciem jakiegoś biskupstwa w Polsce, co mu się zresztą udało, bo w latach 1533-1562 objął stolicę poznańską. Znakomity prałat kapituły krakowskiej Stanisław. Wolski, kustosz krakowski, bawiąc na Mazowszu, przyjął na swego kapelana wypędzonego z Wilna Wawrzyńca Discordię (Niezgodę), głoszącego błędne nauki i żyjącego rozpustnie ${ }^{246}$. Tegoż Stanisława od odstępstwa uratował młodszy brat Mikołaj Wolski, późniejszy biskup włocławski. Mimo niezbyt wielkich efektów synodu prowincjonalnego z r. 1547, doniosłe znaczenie miała jego uchwała o zaleceniu większych wymagań w zakresie wykształcenia kandydatów do kapłaństwa i żądanie podniesienia poziomu kaznodziejstwa w kościołach na polskiej ziemi.

Hozjusz był obecny w Krakowie w dniach, w których dogorywał król Zygmunt Stary i w dniu jego śmierci 1 IV 1548 r. W przewidywaniu okazałych uroczystości pogrzebowych królaa, którego zwłoki miały być złożone w podziemiach kaplicy Zygmuntowskiej, kapituła poczęła się zastanawiać, jak postąpić wobec wielkiej liczby ekskomunikowanych senatorów i członków szlachty, którzy będą chcieli wejść do katedry na ceremonie pogrzebowe, a prawo kościelne wyklętym na to nie pozwalało. Eksskomuniką byli obłożeni ci, którzy dopuścili się grabieży majątku kościelnego czy uporczywie odmawiali płacenia dziesięciny kościelnej. Zwykle łączyło się z tym sprzyjanie nowinkom religijnym. W oczekiwaniu na pogrzeb królewski kapituła wydała 6 lipca 1548 r. dekret przeciw tym, którzy trwają w cenzurze i nie starają się o to, aby w przeciągu roku uzyskać od niej zwolnienie. Byli to tzw. insordescentes ${ }^{247}$. Z tego dekretu kapituła w czasie generalnej debaty odbytej dwa dni przed pogrzebem, tj. 24 lipca, próbowała wyciągnąć konsekwencje i usiłowała

451; H. Barycz, Discordia Wawrzyniec z Przesnysza (u. 1566), [w:] PSB 5, s. 171174.

245 A. Costa, I vescovi di Trento, Roma 1977, s. 153.

246 Cap. Crac. 4 , k. $356-365^{\prime}$.

247 Tamże, k. 266. 
znaleźć odpowiedź na pytanie, czy wolno jej dopuścić ekskomunikowanych na katolickie uroczystości liturgiczne ${ }^{248}$. Zdaje się, że kapituła nie podjęła wiążących decyzji, bo ten problem był przedmiotem dyskusji kapitulnych i w czasach późniejszych ${ }^{249}$.

Po śmierci Zygmunta Starego ukrywający się dotychczas ze swoimi przekonaniami zwolennicy nowinek religijnych poczęli śmiało sobie poczynać. Nie wystarczała im potajemna lektura książek luterskich czy kalwińskich, sprowadzanych z zagranicy, których musieli strzec przed donosicielami, bo rychło zjawiali się wizytatorzy $\mathrm{w}$ ich domach i książki konfiskowali. Właścicieli tych książek pociągano do odpowiedzialności przed sądem inkwizycyjnym. Np. u Jana, snycerza z Krakowa, znaleziono z końcem r. 1548 książkę z tekstem. Marcina Lutra. Stawiony przed sądem artysta tłumaczył się, że tę książkę przechowywał jedynie ze względu na umieszczenie w niej rycin Albrechta Dürera, z których korzystał przy wykonywaniu swego zawodu ${ }^{250}$. Nawet w dalekim Sieciechowie znalazł się denuncjator, który doniósł, że pleban tamtejszy Maciej z Opoczna czyta dzieła Lutra. Wysłana tamże komisja wizytacyjna rzeczywiście te księgi znalazła ${ }^{251}$. Przed połową XVI w. istniał jeszcze wśród skłaniających się ku nowinkom lęk przed inkwizycją. Np. cysters z Mogiły Florian Głuchowski, zdemaskowany jako wyznawca nauki Lutra, ratował się ucieczką do zboru luterskiego w Głubczycach na Sląs$\mathrm{ku}^{252}$. Długo się ze swymi sympatiami dla religijnych tez Lutra ukrywał Franciszek Lismanin, Włoch, mnich franciszkański, ale już w r. 1548 kapituła krakowska znalazła wystarczające podstawy do tego, aby go uznać na odstępcę od wiary katolickiej ${ }^{253}$.

Członkowie kapituły katedralnej w Krakowie doskonale zdawali sobie sprawę, że na początku rządów Zygmunta Augusta odstępstwa od wiary poczęły się szerzyć na dużą skalę. Dlatego postanowiła przystąpić do walki z nowymi dogmatami i podjęła w dniu 20 IV 1550 r. odpowiednią uchwałę ${ }^{254}$. Obawy te nie były próżne, na co wkrótce znalazły się dowody. W maju 1550 r. prawnik Jakub Przyłuski, wyraziciel programu egzekucyjnego, który niedawno (1548 r.) wydał Statuta Regni Poloniae, odważył się publicznie bluźnić przeciw bulli jubileuszowej św. Stanisława ${ }^{255}$. Niedługo potem, we wrześniu, kapituła otrzymała wiado-

248 Tamże, k. 269.

249 Tamże, k. 298 (7 II 1549).

250 Ep. Crac. 21, k. 156.

251 Tamże, k. 318 (28 III 1545).

252 Tamże, k. 444.

253 Cap. Crac. 4, k. 266'; H. Barycz, Lismanini Franciszek (1504-1566), [w:] PSB 17 , s. $465-470$.

254 Uchwała: Novis dogmatibus obsistendum (Cap. Crac. 4, k. 360').

255 Tamże. 
mó́ć, że kapłan Feliks Pomianowski w Chrzanowie rozdaje komunie pod dwiema postaciami, a Feliks z Łowicza, rektor szkoły i notariusz miejski w Wieliczce, bluźni przeciw katolickiej wierze ${ }^{256}$.

W tych krytycznych dla Kościoła polskiego czasach opuścił kapitule i diecezję najzdolniejszy teolog Stanisław Hozjusz; 12 VII 1549 r. został zatwierdzony przez Stolicę Apostolską jako biskup chełmiński ${ }^{257}$. W związku z tym począi rezygnować z beneficjów, jakie posiadał w diecezji i - wyjeżdżając w celu objęcia nowych zadań do diecezji chełmińskiej - zerwał związek z Krakowem ${ }^{25 s}$.

Zatrwożoną groźnym niebezpieczeństwem innowierczego ataku kapitułę krakowską opuścił nie tylko Hozjusz, ale wkrótce potem także jej wpływowy biskup a zarazem kanclerz państwa, Samuel Maciejowski, który niespodziewanie odszedł z tego świata dnia 6 X 1550 r. ${ }^{259}$ Przed śmiercią podjął próbę ratowania wiary diecezji. Kapitule oznajmił zamiar zwołania synodu diecezjalnego i pilnie przygotowywał się do synodu prowincjonalnego na r. $1551^{260}$.

Po śmierci biskupa Maciejowskiego kapituła podjęła odpowiedzialność za stan diecezji, zdając sobie sprawę z powagi sytuacji, w jakiej się znalazł Kościół krakowski. Przede wszystkim zwróciła się do władzy państwowej z prośba o pomoc. W tym celu wysłała dnia $30 \mathrm{X} 1550 \mathrm{r}$. swych współbraci: Jerzego Podlowskiego i Stanisława Górskiego, znanych jako zaufanych dworzan zmarłego kanclerza, do senatorów Królestwa, domagając się kroków, które by zapobiegły szerzącej się herezji ${ }^{261}$. Poza tym postanowiła sama działać i ustanowiła komisję, nakładając na nią zadanie wzywania przed swój sąd i wydawania wyroków na rozzuchwalonych heretyków, a miała tu na myśli takich odstępców od wiary katolickiej, jak Jakuba proboszcza z Krzcięcic, Wawrzyńca kaznodzieję z Pińczowa, Feliksa Krzyżaka (Crucigera) ze Szczebrzeszyna, proboszcza w Niedźwiedziu koło Słomnik ${ }^{262}$, Szymona z Proszowic, niegdyś rektora szkoły katedralnej i kaznodziei w żupach wielickich ${ }^{263}$, który potem z Janem z Koźmina głosił kazania w kościele Mariackim ${ }^{264}$, Stanisława Lasockiego, dziedzica z Pałecznicy, który przyjmował sakramenty more haereticorum i zmuszał kapłanów do małżeństwa ${ }^{265}$, wreszcie najgłośniejszego w die-

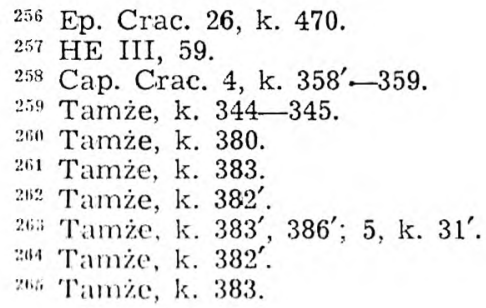


cezji Mikołaja Oleśnickiego, zwanego Jaworskim, który wypędził paulinów z Pińczowa ${ }^{266}$ i publicznie palił obrazy kościelne ${ }^{267}$.

Do powyższej komisji kapituła krakowska wybrała następujących sędziów: Piotra Myszkowskiego, Zygmunta ze Stężycy ${ }^{268}$ i Wojciecha Kijowskiego ${ }^{269}$. Była to jednak decyzja kapituły tymczasowa. Po wyznaczeniu administratora diecezji, którym dopiero 24 XI 1550 r. ${ }^{2 \pi 0}$ został wybrany Jan Przerębski, dodano mu do wykonywania sądów nad heretykami szereg asystentów. Zostali nimi: archidiakon Bartłomiej Gądkowski, Piotr Myszkowski, Zygmunt ze Stężycy, Jakub z Kleparza, Marcin Kromer, Maciej Łącki, Andrzej Przecławski, Jerzy Podlodowski, Piotr Porębski, Rafał Wargawski ${ }^{271}$. Tak ukonstytuowany sąd inkwizycyjny postanowił przystąpić do akcji i rozpocząc przesłuchania podejrzanych w wierze. Pierwszy miał być zbadany Mikołaj Oleśnicki, któremu posłano wezwanie do stawienia się przed trybunałem inkwizycyjnym dnia 10 XII 1550 r. Mikołaj się stawił w terminie, ale - jak mówią akta clamorose $^{2 \tau 2}$, w otoczeniu zaprzyjaźnionej szlachty i licznej służby. Przewodniczący sądu na ten widok odłożył rozprawe. Widać było, że walka z odstẹpcami przy pomocy inkwizycji nie była już w owym czasie łatwa.

Tymczasem po całej diecezji krakowskiej odbywały się procesje na intencję dobrego wyboru nowego biskupa. Ta niezwykła forma błagania o wzorowego pasterza zarządzona przez kapitułę świadczy o tym, jak, bardzo jej zależało, by rządy w Krakowie objął gorliwy przewodnik dusz ${ }^{273}$. W ustalonym terminie, dnia 22 XII 1550 r. kapituła zasiadła w swym krakowskim kapitularzu i na zalecenie królewskie z ciężkim sercem oddała głosy na Andrzeja Zebrzydowskiego ${ }^{274}$.

\section{STAN RELIGIJNO-MORALNY CZŁONKOW KAPITUEY KRAKOWSKIEJ ZA HOZJUSZA}

Kapituła była zespołem beneficjatów skupionych koło kościoła katedralnego. Mieli oni obowiązek wykonywać służbę Bożą w sposób kanoniczny. Oprócz tego kapituła stanowiła senat biskupi, którego członkowie w dużej mierze spełniali ważne funkcje w diecezji, a jeśli chodzi o Kra-

266 Tamże, k. 382', 384'; H. Kowalska, Oleśnicki Mikolaj z Pińczowa, h. Dębno (zm. 1566/7), [w:] PSB 23, s. 768-771.

287 Cap. Crac. 4, k. $388^{\prime}$.

268 Tamże, k. 381.

269 Tamże, $382^{\prime}$.

270 Tamże, k. $392^{\prime}-393^{\prime}$.

271 Tamże, k. 397.

$2 i 2$ Tamże, k. 398'.

273 Tamże, k. 381'.

274 'Tamżc, k. 399', 400' 
ków, także na dworze królewskim. Niemniej ważna była jednak rola kapituły jako korporacji kapłańskiej na świeczniku diecézjalnym, zgodnie z którą winna była pobożnością i wzorem świątobliwego życia świecić przykładem całej społeczności chrześcijańskiej pozostającej pod opieką duszpasterską biskupa.

Rzeczywiście katedra krakowska - jak rzadko inna na świecie rozbrzmiewała modlitwą, recytacją officium i psałterza, śpiewem gregoriańskim w czasie mszy konwentualnej, matury wykonanej przez wikariuszy oraz innych mszy odprawianych przez poszczególne zgromadzenia niższego duchowieństwa, a także śpiewem figuralnym nabożeństw mszalnych w kaplicy Zygmuntowskiej. Dodać jeszcze do tego trzeba, że w kaplicach i przy bocznych ołtarzach, stojących w katedrze, 40 altarystów co pewien czas odprawiało msze fundacyjne. W katedrze krakowskiej nigdy nie milkła chwała Boża, bo 30 wikariuszy już od północy rozpoczynało odmawianie brewiarza, a 15 psalterzystów recytowało psałterz w przerwach między nabożeństwami przez całą dobę, 8 mansjonarzy w kaplicy Mariackiej odmawiało małe officium o NPMarii, roratyści śpiewali codziennie mszę „Rorate”, a nosaliści o św. Krzyżu.

$\mathrm{Na}$ samych członkach kapituły katedralnej ciążył obowiązek odprawiania mszy konwentualnej na zmianę po tygodniu (per hebdomadam).

Ponieważ można było zostać kanonikiem już po przyjęciu niższych święceń, dlatego nie wszyscy członkowie kapituły mogli odprawiać msze konwentualne osobiście, co powodowało, że zmuszeni byli szukać zastępcy między tymi konfratrami, którzy już posiadali święcenia kapłańskie. Kapituła bardzo przestrzegała wypełnianie tego obowiązku i postanowiła dnia 13 V 1541 r., że członkowie kapituły, którzy nie odprawiają mszy tygodniowych per se vel per alium ${ }^{275}$ (osobiście lub przez zastępcę) będą karani, a następnie dnia 14 X 1541 r. określiła, że kanonicy opuszczający mìsze swej hebdomady zapłacą za każdym razem 2 grzywny ${ }^{276}$. Podobne sankcje na terenie kapituły nie były nowością, jednak wobec częsego zdarzania się faktów lekceważenia tego obowiązku musiały być ponawiane. Odprawianie mszy przywiązanych do beneficjów zwykłych (simplex) posiadanych przez członka kapituły w katedrze lub poza katedrą (np. altarie) można było - za udzieleniem stypendium - zwierzać jakiemukolwiek kapłanowi substydowi, czyli lektorowi mszalnemu. Kapituła krakowska zabroniła jednak tej praktyki duchowieństwu stowarzyszeń kapłańskich w katedrze i dnia 14 V 1542 r. postanowiła, że duchowne posady w katedrze mansjonarzy, psałterzystów i innych pre-

275 Dnia 6 X 1546 r. kapituła krakowska postanowiła, że jej członkowie, którzy nie posiadają sacros ordines (przynajmniej subdiakonatu) nie będą mogli wchodzic do kapitularza i będą pozbawieni dystrybucji chónowych (Cap. Crac. 4, k. 183'). 276 Cap. Crac. 3, k. 334. Por.: Ks. I. Polkowski, Statuta capitularia ecclesiae cathedralis Cracoviensis, Kraków 1884, $\mathrm{nr}$ 85, s. 72. 
bendarzy będą obsadzane tylko tymi, którzy posiadają święcenia kapłańskie, aby sami przez się, nie przez zastępców mogli wykonywać swe obowiązki mszalne ${ }^{277}$. Ważnym obowiązkiem kapitulnym była obecność (praesentia) na nabożeństwach w czasie mszy konwentualnej. Kapituła zwalniała swoich konfratrów od tego obowiązku tylko czasowo: np. wysyłanych przez siebie deputatów na sejmy, synody, wizytacje, a także profesorów zajętych wykładami. Np. Stanisław Biel został jeszcze w r. 1529 zwolniony od uczęszczania do katedry w tych dniach, w których miał wykłady $w$ Kolegium ${ }^{278}$; tak samo Jakub z Kleparza otrzymał 22 XII 1542 r. zwolnienie od bywania w chórze na czas zwykłych egzaminów na uniwersytecie ${ }^{279}$, lub specjalnych egzaminów magistrandorum (27 I 1548 r.) ${ }^{280}$. Wyjątkowe takie zwolnienie na stałe mogli uzyskać kanonicy zbyt obciążeni wiekiem, np. dnia 30 IX $1533^{281}$ uwolniony został od obowiązku uczęszczania do katedry Stanisław Biel z powodu upadku sił. Nie spełniających tego obowiązku kapituła upominała z urzędu, np. monitowała $\mathrm{w}$ tej sprawie Wilhelma Jarockiego, który jednak w dalszym ciągu nie chodził do katedry, zasłaniając się chorobą ${ }^{282}$. Zdarzył się wypadek braterskiego upomnienia w podobnej sprawie Benedykta Izdbienskiego przez kolegę Pawła Krassowskiego ${ }^{283}$. Co do obecności członka kapituły w chórze zebranie kapitulne w Krakowie podjęło szereg uchwał. Ustalono raz na zawsze w dniu 28 I 1547 r., że asystowanie przez członka kapituły przy funkcji pontyfikalnej biskupa, gdziekolwiekby się ono odbywało poza katedrą, będzie liczone za obecność na mszy w tym samym czasie odprawianej w głównym kościele ${ }^{284}$. Specjalnego przywileju udzieliła kapituła dwom prałatom, to jest prepozytowi i dziekanowi kolegiaty Wszystkich Swiętych w Krakowie, których zwolniła od uczestniczenia $\mathrm{w}$ katedralnej ciemnej jutrzni (matutinum tenebrosum) $\mathrm{w}$ Wielki Czwartek ze względu na to, że w podobnym nabożeństwie przewodniczyli w kolegiackim kościele. Obecność w czasie celebry w kościele Wszystkich Swiętych uznano za obecność w katedrze ${ }^{285}$. Aby konfratrów kapitulnych zachęcić do uczestniczenia w nabożeństwach chórowych, uchwalono dnia 7 III 1550 r., że ci członkowie kapituły, którzy będą pilnie

277 Cap. Crac. 4, k. 255 Dnia 9 X 1540 r. krakowska kapituła katedralna zganiła sytuację, że 'w Sandomierzu scholarzy wyręczają wikarych kolegiackich w odmawianiu brewiarza - divina officia (Cap. Crac. 3, k. 270-270').

278 Cap. Crac. 3, k. 41.

279 Tamże, k. 396.

280 Cap. Crac. 4, k. $242^{\prime}$.

281 Cap. Crac. 3, 1. 105.

282 Tamże, k. 327'; Cap. Crac. 133.

283 Cap. Crac. 3, k. 327. Do zaniedbujących obowiązki kapitulne należeli również Stanisław Wolski (Cap. Crac. 4, k. 391-391'), który podobnie jak Czarnkowski, Jarocki i Hieronim Rosborski w ogóle mszy per se nie odprawiali (Cap. Crac. 4, k. $\left.326,328,335^{\prime}-336,365-365^{\prime}\right)$.

284 Cap. Crac. 4, k. 201.

285 Tamże, k. 232. 
uczçszczali do katedry, będą mieli prawo do większych łask i wzglẹdów kapituly, np. przy optowaniu wsi prestymonialnych ${ }^{286}$.

W normalnym biegu nabożeństw katedralnych mogły nastąpić zakłócenia; ich przyczyną bywały najazdy nieprzyjacielskie lub najścia morowego powietrza. Za czasów Hozjusza nie było inwazji wroga, ale dwa razy pojawiła się w Krakowie zaraza: w sierpniu 1543 r. ${ }^{287}$ i w czerwcu $1547^{288}$. W czasie moru kapituła krakowska się rozbiegała, chroniąc siç zwykle do swoich wsi prebendalnych lub prestymonialnych, oddalonych cd miasta. Odważni albo tacy, którzy nie mieli za co wyjechać i sami odprawiali nabożeństwa w katedrze, byli za to specjalnie wynagradzani z kasy kapitulnej. Np. Jakub z Kleparza i Stanisław Przeborowski, którzy w czasie zarazy w r. 1543 rezydowali przy katedrze, dostali po 10 grzywien, a wiceprokurator kapituły, który również w Krakowie pozostał - 5 grzywien ${ }^{289}$. Szczególne zubożenie nabożeństw katedralnych sprawiło wyjście żaków z Krakowa w czerwcu 1549 r., kiedy zabrakło scholarów do pomocy $w$ ceremoniach, do wykonywania śpiewów liturgicznych, do noszenia świec i sztandarów ${ }^{290}$. Członkowie chóru kanonikalnego byli na zebraniach upominani, gdy zauważono jakieś niestosowne zachowanie się $w$ stallach, np. rozmowy w czasie służby Bożej ${ }^{291}$.

Wielki aparat liturgiczny w katedrze mógł sprawnie działać, jeżeli były dokładnie zachowane jego przepisy. Kapituła odznaczała się dużą wrażliwością na wszelkie uchybienia przeciw liturgicznemu porządkowi ${ }^{292}$. Strzegła nawet nie ustalonych pisanym prawem zwyczajów, np. że wikary tylko osobiście, a nie przez zastępcę, ma swemu kanonikowi nakładać na ramiona kapę chórową, a później zdejmować ${ }^{293}$. Kapituła bardzo była oburzona na widok udzielania święceń kapłańskich przez sufragana Andrzeja Spota poza i z pominięciem mszy św. Natychmiast tę sprawę skierowała do biskupa Samuela Maciejowskiego ${ }^{294}$. Nie oszczędziła również swego wikarego katedralnego Adama z Bełżc, który udzielił ślubu małżeńskiego bez wygłoszenia uprzednio zapowiedzi; na skutek oskarżenia go przez wikarych parafii Wszystkich Swiętych został skazany na zapłacenie znacznej kary synodalnej w wysokości trzech grzywien ${ }^{295}$.

W monotonii trwających przez całą dobę recytacji psalmodii i zaczy-

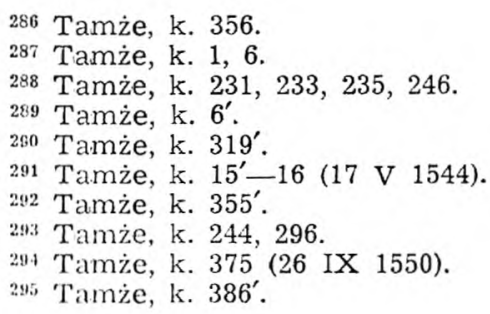


nających się przed świtem ceremonii mszalnych, ożywczym akcentem było głoszenie słowa Bożego. Obowiązek ten wykonywali beneficjaci uniwersyteccy, ale szczególnạ rolę odgrywał oficjalny kaznodzieja kapitulny (praedicator ordinurius). Do tych głosicieli słowa Bożego w czasach Hozjusza należał profesor teologii Jakub z Kleparza, następca słynnego Jana Leopolity (od 19 III 1935 r.) ${ }^{296}$, który ten urząd pełnił do 21 XI 1544 r., po czym ustappił z powodu braku zdrowia ${ }^{297}$. Następnym kaznodzieją został na polecenie samego odchodzącego Jakuba - Leonard Wyszogrodzki, zatwierdzony przez Piotra Gamrata. Dwa lata później Leonard objął biskupstwo kamienieckie, a kapituła na życzenie biskupa S. Maciejowskiego obrała na jego miejsce Eukasza z Orłowa (Aquilinusa) ${ }^{298}$, bakałarza św. teologii, dotychczasowego kaznodzieję w kościele Mariackim (późriej przez dwa lata, 1547-1549, plebana w Bieżanowie). Prócz zwyczajnego kaznodziei, na ambonę w katedrze krakowskiej wychodzili także sami członkowie kapituły. Do nich należeli: Jan Wilamowski, Jerzy Myszkowski i Samuel Maciejowski. Doliczyć do tej trójki trzeba jeszcze Hozjusza wygłaszającego egzorty na prośbę kapituły ${ }^{299}$. Z ciekawą inicjatywą wystąpiła w marcu 1546 r. królowa Bona. Przedłożyła ona kapitule propozycje, by w Wielkim Poście były głoszone w katedrze - pewnie zwyczajem włoskim - kazania dwa razy w tygodniu ${ }^{300}$.

Celem działalności kaznodziejskiej jest nawrócenie słuchacza i skłonienie go do pojednania z Bogiem. Dlatego prócz kaznodziejów potrzebni byli w katedrze i penitencjarze. Gdy Hozjusz wszedł do kapituły jednym ze spowiedników był przez krótki czas Jan z Sanoka, surogat wikarego generalnego Mikołaja Bedleńskiego. Następcą Jana z Sanoka był cd 22 IX 1542 r. Adam Matla, doktor obojga praw ${ }^{301}$. W myśl fundacji biskupa Jana Konarskiego, w katedrze było uposażonych dwóch spowiedników. Drugi konfesjonał zajmował po doktorze teologii Janie z Krakowa Maciej z Kościana ${ }^{302}$, również profesor teologii od 18 III 1541 r. aż do śmierci w r. 1545. Po Macieju był spowiednikiem Jan z Piotrkowa ${ }^{303}$, także profesor teologii, kanonik kolegiaty św. Floriana, przedtem kaznodzieja w kolegiacie Wszystkich Swiętych. Posługiwanie w kon-

296 Jakub z Kleparza był przedtem penitencjarzem katedralnym (Conarscianus) po śmierci Mikołaja Mikosza, profesora teologii, od 3 III 1528 r. (Cap. Crac. 3, k. $\left.29^{\prime}\right)$.

207 Cap. Crac. 4 , k. $38^{\prime}$.

299 Tamże, k. 184; Henryk Barycz, Aquilinus Łukasz (um. 1559), wybitny kaznocizieja polski XVI w., [w:] PSB 1, 147.

$29: 1$ Tamże, k. 221.

:tuin 'Tamże, k. 130'.

$3 n$ Cap. Crac. 3 , k. 369, 388'.

3n2 Snierc jego jest zapisana 21 XI 1545 r. w t. 4 aktów kapitulnych, które go suwią: vir integerrimus et eruditissimus - por. Wip. źródl. II, nr 47, p. 2, s. 38 .

:3a: Cap. Crace 4, k. 125' i 126. 
fesjonałach katedry krakowskiej przez penitencjarzy z fundacji J. Konarskiego - sądząc $\mathrm{z}$ tego, że do nich powoływano zwykle profesorów teologii i prawa - z pewnością stało na wysokim poziomie.

Członkowie kapituły krakowskiej odprawiali swe modły w prezbiterium zamkniętym od zachodu grobem. św. Stanisława. Sami uważali się za stróżów tego grobu, a katedrę za sanktuarium świętego Patrona kościoła, miasta i Polski. Kapituła postanowiła wykorzystać duży ruch pielgrzymkowy, jaki się kierował do grobu Patrona Polski, dla celów duszpasterskich, a zarazem dla większego rozwoju czci pierwszego polskiego męczennika. Czyniła to szczególnie przez obchód roku jubileuszowego św. Stanisława ${ }^{304}$. Przez szereg lat kapituła, spodziewając się większego napływu pielgrzymów, przede wszystkim starała się obsadzić spowiednikami sporą ilość konfesjonałów i corocznie wyznaczała komisarzy, którzy mieli się zając wyborem i wyznaczaniem kapłanów do słuchania spowiedzi ${ }^{305}$. Do składu tych komisarzy prawie zawsze należeli profesorowie Jakub z Kleparza i Zygmunt ze Stężycy, a prócz nich oficjał, kanclerz kurii i prokurator kapitulny ${ }^{306}$.

Kraków czcił św. Stanisława corocznym obchodem w święto majowe, ale główna zeẉnętrzna uroczystość była przenoszona na piątek najbliższy po 8 maja, której najwspanialszą częścią była solenna procesja przechodząca z Wawelu przez most Królewski na Skałkę ${ }^{307}$. Przed nadejściem święta Patrona narodu kapituła krakowska przypominała księżom nie tylko z Krakowa, ale i z Kazimierza o obowiązku wzięcia udziału w tej procesji ${ }^{308}$. Do innych objawów czci św. Stanisława w krakowskim Kościele było przeniesienie nabożeństw, jakie były odprawiane w kaplicy kapitulnej św. Mikołaja do ołtarza'św. Patrona ${ }^{309}$. O wielkiej czci dla św. Stanisława w polskim narodzie świadczą liczne prośby płynące, do kapituły krakowskiej o udzielenie relikwii św. Męczennika. Kapituła zachowywała się wobec tych próśb bardzo powściągliwie i nie łatwo skłaniała się dawać cząstki z kości świętego ${ }^{310}$.

Prócz najokazalszej procesji ku czci św. Stanisława, wychodziły z katedry krakowskiej mniejsze procesje przepisane przez rytuał krakowski (np. w dzień św. Floriana). W celu ożywienia pobożności krakowian ka-

304 Bulla jubilei (tamże, k. 261).

305 Tamże, k. 150.

306 Tamże, k. 150' (1546) i 307 (1549).

307 'Tamże, k. 13' (14 V 1544); k. 152 (11 V 1546), k. 223' (12 V 1527), k. 253 (11 V 1548), k. $307^{\prime}$ (10 V 1549) zanotować jeszcze należy, że 'w r. 1530, w przeddzień koronacji Zygmunta Augusta, odbyła się 19 II procesja z Wawelu na Skałkę, przepisanja ceremonialem koronacyjnym - por. IM. Jagosz, Procesje ku czci Sw . Stanistawa z Wawelu na Skałkę $w$ okresie przedrozbiorowym, ,Analecta Cracoviensia“ 11 (1979) s. 609.

308 Cap. Crac. 4 , k. $11^{\prime}$ (18 IV 1544).

309 Cap. Crac. 3, k. 264' (13 VIII 1540).

310 Tamże, k. $307^{\prime}$. 
pituła zapowiadała specjalne procesje, np. o pomyślność dla Rzeczypospolitej ${ }^{311}$ lub o pomyślny wybór nowego biskupa ${ }^{312}$. Dużo ludzi w katedrze gromadziła tradycyjna rezurekcja. Aby podkreślić i zachować dla katedry centralny charakter tej uroczystości, kapituła zabraniała innym kościołom krakowskim odprawiać u siebie rezurekcję o tej samej godzinie, o której'była odprawiana na Wawelu. Dopiero, gdy z wieży Zygmuntowskiej zabrzmiał dzwon na zakończenie uroczystości, kościoły krakowskie mogły zaczynać swój obchód paschalny ${ }^{313}$. Wielkie usługi tym staraniom o rozwój służby Bożej w katedrze oddawali uczniowie szkoły katedralnej na Wawelu. Oni wykonywali śpiewy na procesjach, nosili świece i chorągwie, dlatego kapituła starała się im to wynagradzać. Co kwartał wypłacała im z kasy jubileuszowej pewne datki, zapewniała im co pewien czas rozrywki dla zabawy szkolnej, np. w święto Arystotelesa, jak i w Zapusty (Bacchanalia), zabraniając im jednak używać do tych zabaw szat liturgicznych ${ }^{314}$.

Po skończonych nabożeństwach wracali członkowie kapituły do swoich kurii kanonicznych i tu ich otaczały kłopoty gospodarcze. Każdy z nich miał w zarządzie swą prebendę kapitulną, majątek prestymonialny, czasem dziesięciny darowane przez biskupa. W domu czekali na nich faktorzy, którzy doglądali z ich polecenia folwarki beneficjalne, zgłaszali się do swego mocodawcy po różne instrukcje i polecenia. W okresie zbioru dziesięcin tak faktorzy, jak i specjalni sprzedawcy dziesięcin (venditores decimarum) dawali sprawozdanie o dochodach. Część tych dochodów wracała na folwark, gdzie trzeba było poprawić budynki dworskie, postawić nową stodołę, oczyścić stawy, rybne, wyremontować karczmę-zajazd, czy przebudować młyn itp. Gdy członkowi kapituły wypadły wakacje (mensis messium vel vindemiarum), jechał do swych majątków, aby zobaczyć, w jakim są stanie. Inną część dochodów trzeba było odłożyć na naprawę kurii kanoniczej w mieście, bo każdy jej posiadacz był obowiązany wypełnić warunki remontowe, nałożone przez kapitułę w akcie przekazania domu, np. wyremontowanie całego piętra, fasady, poprawę dachu, postawienie muru granicznego w celu uniknięcia scysji z sąsiadami. Niektórzy posiadacze domów kapitulnych podejmowali się gruntownego remontu, jak np. Jan Naropiński na Wawelu (Wawel 3), Stanisław Borek w domu przy ul. Kanoniczej 21, Mikołaj Bedleński (ul. Kanonicza 15 i Zerwikaptur), Andrzej Zebrzydowski w domu przy ul. Kanoniczej 12 i Samuel Maciejowski w domu ,św. Grzegorza” (ul. Kanonicza 1). Określenie przy tych remontach ,a fundamentis" nie zawsze należy brać

\footnotetext{
311 Cap. Crac. 4, k. 12 (12 V 1544).

312 Tamże, k. $381^{\prime}$.

313 Cap. Crac. 3, k. $306-306^{\prime}$.

314 Cap. Crac. 4 , k. 351.
} 
dostownie, oznacza ono jedynie gruntowną restaurację budynku. Dalwa! cześć dochodu trzeba było obrócić na zapłacenie do kasy kapituly rocznej pensji z domu (40 grzywien) i dwóch albo trzech grzywien na anniwersarz za duszę fundatora czy dobrodzieja, który włożyl wiclki wkład w budowę czy rozbudowę domu. Posiadacz prestymonium placil taksę obracaną na dystrybucje chóralne. Bywało, że niektórzy z członków kapituły zalegał całymi latami z opłatą za cappalia, jaką był winien złożyć przy instalacji kanoniczej (14 grzywien). Te pieniądze płacono prokuratorom kapituły. W czasach Hozjusza byli nimi: w r. 1540 Kasper Podłęski i Mikołaj Miłkowski oraz dodany do pomocy Maciej Drzewicki, kustosz włocławski ${ }^{315}$, w r. 1541 Kasper Podłęski i Benedykt Izdbieński, wikariusz generalny ${ }^{316}$, w r. 1542 Kasper Podłęski i Maciej Drzewicki, w r. 1543 Stanisław Konarski i Benedykt Izdbieński ${ }^{317}$, w r. 1544 Benedykt Izdbieński i Jan Drohojowski ${ }^{318}$, w r. 1545 Piotr Myszkowski i Piotr Porębski ${ }^{319}$, w r. 1546 Piotr Porębski i Bartłomiej Gądkowski ${ }^{20}$, w r. 1547 Bartłomiej Gądkowski i Wojciech Kijowski ${ }^{321}$, w r. 1548 Wojciech Kijowski i Filip Padniewski ${ }^{322}$, w r. 1549 Maciej Drzewicki i Wojciech Kijowski ,diligens et dexter", ${ }^{323}$, i ciz sami w roku następnym (1350) ${ }^{324}$. Powyższy wykaz wskazuje, do kogo kapituła miała największe zaufanie, oddając w ręce wybranych prokuratorów cały swój majątek. Z nich okazali się dwaj niedbali: Stanisław Konarski i Jan Drohojowski, za to Benedykt Izdbieński był badzo pracowity, ale nie całkiem pewny co do swej uczciwości ${ }^{325}$, Kasper Podłęski doprowadził kasę kapituły do zupełnej ruiny, zostawiając po śmierci $w$ rachunkach kapitulnych olbrzymie długi ${ }^{326}$. Czynności prokuratora były bardzo czasochłonne, dlatego nie zlecano ich ludziom nauki, np. Hozjuszowi czy Kromerowi, ani profesorom uniwersytetu.

Niezmiernie przykre, a nawet bolesne były dla kapituły fakty okupacji dóbr kapitulnych przez konfratrów, którzy zostawszy biskupami i tracąc według prawa kościelnego per munus consecrationis beneficja kapitulne, nie chcieli oddać ani domów, ani wsi prestymonialnych dotychczas przez nich posiadanych. Do tych okupantów należeli: Stanisław Tarło w r. 1537 wyniesiony na biskupstwo przemyskie, Samuel Macie-

\footnotetext{
315 Cap. Crac. 3, k. 259.

316 Tamże, k. 308'.

317 Tamże k. 419'.

318 Cap. Crac. 4, k. 15'.

319 Tamże, k. 77'.

320 Tamże, k. 156-156'.

321 Tamże, k. 227.

322 Tamże, k. 257-257'.

323 Tamże, k. 316'.

24 Tamże, k. 367.

32. Tamze, k. 71'.

(2ม1 Tamze, k. 166.
} 
jowski - w r. 1539 został biskupem chełmskim, a w r. 1541 przeniesiony na biskupstwo płockie, i Andrzej Zebrzydowski — od r. 1543 biskup kamieniecki, potem (w r. 1545) biskup chełmski, zaś w r. 1546 przeniesiony na Kujawy.

Stanisław Tarło, obejmując biskupstwo przemyskie, zatrzymał dom kanonikalny (ul. Kanonicza 3) i wieś Witkowice koło Krakowa. Mimo upomnień kapituły Tarło nie ustąpił. Kapituła ustanowiła solicytatora — opiekuna zajętej wsi, którym został Bartłomiej Gądkowski ${ }^{327}$. Drugim okupantem majątku kapitulnego był Samuel Maciejowski, biskup chełmski. Zajął dom przy ul. Kanoniczej 1, przez niego - niegdyś kanonika krakowskiego - odbudowany wspaniale, i majątek kapitulny w Pabianicach, gdzie był długoletnim regentem ${ }^{328}$. Kapituła, pragnąc zabezpieczyć swoje prawa,i swój wpływ na sprawy Pabianic, mianowała dwóch starostów albo gubernatorów w osobach Benedykta Izdbieńskiego i Mikołaja Miłkowskiego ${ }^{329}$ i zleciła im nadzór nad zajętą własnością kapitulną. Gdy biskup S. Maciejowski otrzymał od króla nominację ra biskupstwo plockie, zrezygnowal z Pabianic, a 18 VII $1541 \mathrm{r}$. Mikołaj Miłowski objął Pabianice jako regent z ramienia kapituły ${ }^{3: 0}$. Dom „Św. Grzegorza” przy ul. Kanoniczej 1 kapituła - wdzięczna za jego odbudowę - zostawiła Samuelowi w dożywocie; w tym domu mieszkał w dalszym ciągu od r. 1546 jako biskup krakowski, tamże prowadził kancelariẹ kurialną i w tym domu zmarł w r. 1550. Trzecim zaborcą dóbr kapitulnych był Andrzej Zebrzydowski, od r. 1543 biskup kamieniecki. Zatrzymał dla siebie kamienicę przy ul. Kanoniczej 12, którą na jego zlecenie odbudowała włoska spółka w stylu renesansowym ${ }^{331}$. Tę kamienicę kapituła — bacząc na wielki wkład, jaki w nią włożył zostawiła mu w dożywocie, ale absolutnie zażądała oddania prestymonialnej wsi Łososkowice, leżącej w ziemi proszowickiej, którą utracił per munus consecrationis ${ }^{332}$. Wobec oporu obu biskupów, tak Stanisława Tarły, który trzymał Witkowice, jak i Andrzeja Zebrzydowskiego, który okupował Łososkowice, kapituła postanowiła dnia 15 V 1544 r. zwrócić się w tej sprawie do Stolicy Apostolskiej i w tym celu wybrała Filipa Padniewskiego jako swego posła i prokuratora ${ }^{333}$. Mianowała także do tej sprawy prokuratorów mieszkających w Rzymie ${ }^{334}$, a mianowicie:

327 Cap. Crac. 3, k. 297, 303, 311-311'; 4, k. 13.

328 Cap. Crac. 3, k. 251, 252, 254'.

329 Tamże, k. 257-257' (20 V 1540).

330 Tamże, k. 316.

331 B. Przybyszewski, Zatarg Andrzeja Zebrzydowskiego, kanonika (pózniej biskupa krakowskiego) z muratorami wloskimi, „Sprawozdania Polskiej Akademii Umiejętności“ 1 (1949) nr 2, s. 42-43.

${ }^{332}$ Cap. Crac. 4 , k. 9, 10, 10', 70-70, 78, 122.

333 Tamże, k. 13, 14.

${ }_{334}$ Tamże, k. 27'. 
Stanisława z Rzeczycy, penitencjarza apostolskiego, dziekana kieleckiego, Jana Chrzciciela de Rochetis, Leonarda Hermana i Jana Dębińskiego ${ }^{335}$.

Ta swawola biskupów, dawnych konfratrów, dużo kosztowała kapitułę, która musiała opłacić kilku prokuratorów rzymskich, a swego wysłannika z Krakowa zaopatrzyć na drogę i opłacić koszta jego podróży. Filipowi Padniewskiemu przed jego wyjazdem do Rzymu kapituła wręczyła 50 dukatów w złocie ${ }^{336}$. Padniewski wybrał się do Rzymu z końcem sierpnia 1543 r., a w styczniu 1544 r. ${ }^{337}$ już działał w Rzymie ${ }^{338}$ i po roku pobytu w Stolicy Apostolskiej wrócił do Krakowa w sierpniu 1544 r. ${ }^{339}$ Gdy we wrześniu 1544 r. przyszła z Przemyśla do Krakowa wiadomość o śmierci Stanisława Tarły ${ }^{340}$, wówczas kapituła nie omieszkała ogłosić Witkowice za wakujące i nadała je Maciejowi Zieleńskiemu. Zebrzydowski jednak trzymał Łososkowice dalej, aż do czasu, kiedy został obrany biskupem krakowskim i wówczas zrezygnował z tej wsi, którą po nim wziął 8 I 1546 r. Zbigniew Ziółkowski ${ }^{341}$.

W ten sposób zakończyły się sprawy bardzo gnębiące kapitułę, obawiającej się alienacji dobra kapitulnego. Miała ona naoczny przykład, jak po śmierci Andrzeja Krzyckiego, posiadającego kamienicę narożną przy wodociągu od strony Wawelu (ul. Kanonicza 24), urządzoną przezeń dla prymasów polskich, zagarnęła po jego śmierci rodzina. Dom, który miał być siedzibą arcybiskupów gnieźnieńskich, dzierżyła za Hozjusza rodzina Górków wielkopolskich (Domus Gorcana) ${ }^{342}$.

335 Jan Dębiński (Dębnicki, Dębieński), h. Poraj, syn Mikołaja, doktora medycyny w Poznaniu, prokurator rzymski, 1546 kanonik poznański, dnia 5 XII 1550 przyjęty do kapituły krakowskiej (Cap. Crac. 4, k. 396-397), prepozyt sandomierski w $1561 \mathrm{r}$.

${ }^{336}$ Cap. Crac. 4 , s. $26-26^{\prime}$.

397 Tamże, k. 28-29.

338 Tamże, k. 50.

${ }_{339}$ Tamże, k. 87-88. W czasie kanonikatu krakowskiego St. Hozjusza kapituła wysłała do Rzymu kolejno trzech swych przedstawicieli, gdy się musiała bronić przed przywłaszczycielami jej dóbr, tj. przed Stanisławem Tarłą - zajął kamienicę i Witkowice, Samuelem Maciejowskim okupującym majątek kapitulny w Pabianicach, Andrzejem Zebrzydowskim, który zuchwale oświadczył kapitule, że jej Łososkowic nie odda. Pierwszym wysłańcem kapituły był Melchior Sobek, który wrócił 16 IV 1540 (Cap. Crac. 3, k. 251'), drugim Stanisław Konarski wysłany 4 IX 1541 (Cap. Crac. 3, k. 338', 339', 340, 342) i odwolany 11 VIII 1542 (Cap. Crac. 3, k. 355), trzecim Filip Padniewski od 1 VIII 1544 (Cap. Crac. 4, k. 26-26'; Cap. Crac. 4, k. 50, 70') do 1 VIII 1545 (tamże, k. 87'-88). Specjalny wysłannik biskupa P. Gamrata Marcin Kromer po przyjeździe przedstawił kapitule 12 IX 1544 dużo uzyskanych w Stolicy Apostolskich dokumentów (Cap. Crac. 4, k. 32). Tenże M. Kromer był znów wysłany do Rzymu po śmierci Zygmunta Starego 15 VI 1548 (tamże, k. 261'). Za czasów S. Maciejowskiego kapituła posługiwała się kanonikami studentami rzymskimi, np. Hieronimem Rosborskim (Ciap. Crac. 3, k. $300-4$. III 1541) i Janem Podlodowskim (Cap. Crac. 4, k. 320 - rok 1549). Chętnie służyli swą wiedzą prawniczą prokuratorowie zawodowi, stale mieszkający w Rzymie, m. in. Jan Dębiński (4 VI 1549, Cap. Crac. 4, k. 319), później kanonik krakowski (5 XII 1550).

340 Cap. Crac. 4, k. $32,46$.

341 Tamże, k. 128.

342 O domie Różyców Koniecpolskich por.: Wp źródł. II, nr 159, s. 133. 
Członkowie kapituły krakowskiej, posiadając prebendy i prestymonia kanonikalne, mieli wielu poddanych pracujących w ich majątkach, jak też pewną liczbę służby w domach kanonicznych. W większości wypadków zachowanie się panów kapitulnych wobéc tych ludzi było poprawne, lecz bywały przykre wyjątki. Dola poddanych w dobrach duchownych bywała ciężka, jak świadczy o tym synod prowincjonalny z r. 1551, który potępił nieludzkie traktowanie poddanych w biskupich dobrach stołowych i apelował o sprawiedliwe, łagodne i ojcowskie odnoszenie się do nich ${ }^{343}$. P.od tym względem można by wiele zarzucić również niektórym członkom kapituł. Choć szlachecka kapituła krakowska, dumnie obnosząc się ze swymi herbami, z pogardą patrzyła na plebejuszów i wiele przykrości wyrządziła Hozjuszowi i Kromerowi przy przyjmowaniu ich do swego grona ${ }^{34}$, to jednak jako całość broniła poddanych we wsiach kapitulnych przed nadmiernym ich obciążaniem i przed niesprawiedliwóścią.

Do ciemiężycieli ludzi w czasach Hozjusza należeli w pierwszym rzędzie obaj bracia Sobkowie z Sulejowa, siostrzeńcy kanclerza Krzysztofa Szydłowieckiego. Nie tylko z nazwiska, ale i w życiu nieużyci i sobiepany. Nie byli lubiani w kapitule; sam Hozjusz nie utrzymywał z nimi żadnych kontaktów. Melchior miał kapitulną wieś Rudawę i tak gnębił tamtejszych poddanych, że otrzymał $\mathrm{w}$ tej sprawie surowy dekret kapituły ${ }^{345}$. Podobny brak serca dla poddanych okazywał jego brat Zygmunt, regent Borka. Chłopów - jak podają akta kapitulne - bił biczami (flagellis) i wtrącał do więzienia ${ }^{346}$. Zabronił chłopom w Borku otwierania drzwi od strony dóbr kapitulnych ${ }^{347}$. I on równie dnia $30 \mathrm{VI}$ 1550 r. został upomniany przez kapitułę z powodu złego traktowania poddanych ${ }^{348}$.

Nieszczęśliwi byli mieszkańcy biskupiego Bodzentyna. Tamtejszą regencję po śmierci biskupa P. Gamrata objął Andrzej Zebrzydowski wraz z Hieronimem Rosborskim. Służba Rosborskiego napadła na miasto, zabiła niewinnego człowieka i obrabowała mieszkańców ${ }^{349}$. Sam Rosborski tyle uczynił szkód w tamtejszych dobrach kapitulnych, że przez wiele lat ciążyła na nim ekskomunika ${ }^{350}$. Jego następcą był prefekt biskupi

${ }^{343}$ Ignacy Subera, Synody prowincjonalne arcybiskupów gnieźnieńskich, Warszawa 1971, s. 127.

${ }_{344}$ Cap. Crac. 3 , k. 245-245'; 4, k. 4-4', 195'-196.

845 Cap. Crac. 3, 263-263' (13 VII 1540). Nie dość, że Melchior Sobek gnębił chłopów w Rudawie, to jeszcze szlachta z pobliskich Radwanowic napadała na nich (Cap. Crac. k. $37-30$ X 1544). Walka chłopów z Rudawy przetrwała do lat 60 -tych wieku XVI, na nowo podjęta z Andrzejem Przecławskim (Cap. Crac. 5, k. 64-65, $\left.107,248^{\prime}, 269^{\prime}\right)$.

346 Cap. Crac. 4, k. $368^{\prime}, 369^{\prime}$.

347 Cap. Crac. 3 , k. 249.

348 Tamże, k. $369^{\prime}$.

349 Cap. Crac. 4, k. 119' (skarga zaniesiona dnia 20 XI 1545).

350 Tamże, k. 213'. 
i starosta Bodzentyna Jan Potkański. I ten wiele wyrządził krzywd tamtejszym mieszkańcom, że ich spis wypełnił duży kwintern ${ }^{351}$.

W dobrach kapitulnych pojawiło się również zbiegostwo. W r. 1541 wpłynęła do kapituły skarga na Feliksa Naropińskiego, że przyjął do Pychowic chłopa z rodziną, który opuścił inny majątek ${ }^{352}$. Nie wiadomo, czy ten zbieg, który za teren swej pracy obrał pola pychowickie, był później ze zmiany zadowolony, bo w tej wsi za Bartłomieja Gądkowskiego zaczęła się wielka niedola chłopska ${ }^{353}$. Kmiecie posunęli się nawet do porzucenia pracy ${ }^{354}$. Nie ustaje gnębienie chłopów w Pychowicach i za następnego regenta, nepota biskupiego Jerzego Podlodowskiego ${ }^{355}$. Inny ulubieniec biskupa Samuela Maciejowskiego Benedykt Izdbieński dręczył chłopów w swej wsi prestymonialnej Wąsowie koło Ruszczy ${ }^{356}$.

Dużo cierpień poddanym dóbr kościelnych zadawali - jak wyżej podano - krewniacy biskupa S. Maciejowskiego. Sam Samuel przez dłuższy czas wzbraniał się zwrócić kapitule krakowskiej jej wielki majątek w komitacie pabianickim. Gdy wreszcie zrezygnował z tamtejszej regencji, pozostała do załatwienia tocząca się od października $1542 \mathrm{r}$. sprawa wynagrodzenia szkód wyrządzonych tamtejszym mieszkańcom w czasie zarządzania Pabianicami przez Maciejowskich i ich faktorów ${ }^{357}$. Szczególnie za te krzywdy był odpowiedzialny ojciec biskupa Bernard Maciejowski, kasztelan lubelski ${ }^{358}$.

Samuel Maciejowski popierał swych krewniaków i obdarzał ich dochodami kościelnymi. Jednego z nich osadził w majątku biskupim Sławkowie. Był to mąż jego siostry Urszuli Jan Leżeński, ojciec trzech kanoników krakowskich: Mikołaja, Jana i Mariana ${ }^{359}$. Leżeński do tego stopnia krzywdził chłopów klucza sławkowskiego, że sama kapituła krakowska zwróciła się dnia 26 IX 1548 r. do niego z prośbą, by zachował dawne zwyczaje i nie obarczał tamtejszych kmieci nowymi ciężarami oraz niezwykłymi pracami ${ }^{360}$. Mimo to ucisk (gravamina) poddanych zamku sławkowskiego nie ustawał, dlatego chłopi z Jaworzna dnia $17 \mathrm{X}$ 1550 r. w czasie nieobecności kasztelana wnieśli skargę do kapituły na

351 Tamże, k. 160'.

352 Cap. Crac. 3, k. $303^{\prime}$.

353 Cap. Crac. 4, k. 61.

354 Tamże, k. 63.

355 Tamże, k. $234^{\prime}$ (1547 r.).

356 Cap. Crac. 3, k. $422^{\prime}$.

357 Tamże, k. 391'.

358 Cap. Crac. 4 , k. $59-60$.

${ }^{359}$ Brat biskupa S. Maciejowskiego Stanisław, kasztelan wojnicki, posiadał nadane mu przez brata wsie biskupie Jaksice i Biskupice. Takie nadanie traciło ważność z chwilą śmierci biskupa, ewentualnie do czasu wyboru nowego biskupa wymagało ponownego potwierdzenia przez kapitułę (Cap. Crac. 4, k. 313', 383'-384). ${ }_{360}$ Cap. Crac. 4, k. $281^{\prime}$ (26 IX 1548). 
wicestarostę Zbudzyńskiego, żaląc się na ciężkie krzywdy im wyrządzone. Wówczas kapituła 'w sprawie tej skargi zwróciła się do żony kasztelana i starosty sławkowskiego Urszuli, czuwającej wówczas przy łożu umierającego brata Samuela ${ }^{361}$. Gdy to nie pomogło, mieszkańcy Jaworzna odmówili posłuszeństwa staroście. Wtedy Zburzyński zarządził zajęcie kmieciom bydła, które miało stanowić zastaw i rękojmię wykonania przez mieszkańców Jaworzna narzuconych im przez tentariusza ciężarów. Chłopi wiedząc z doświadczenia, że zajęte bydło już do nich nie wracało, rzucili się zbrojnie na towarzyszy wicestarosty i odbili bydło, lecz dwóch spomiędzy kmieci jaworznickich zostało śmiertelnie zranionych. Chłopi rozproszyli się (profugi et vagi). Kapituła na miejsce zamieszek wysłała Stanisława Słomowskiego, dając mu władzę (wraz z jednym $\mathrm{z}$ egzekutorów testamentu zmarłego $\mathrm{w}$ międzyczasie biskupa S. Maciejowskiego) wtrącenia winnych do więzień w Lipowcu lub w Siewierzu ${ }^{362}$. Rzeczywiście więzienia zapełniły się mieszkańcami Jaworzna ${ }^{363}$. Kapituła, rządząca sede vacante diecezją krakowską, zażądała dokładnego sprawozdania na temat obowiązków kmieci z Jaworzna i ich attentatu, które otrzymała dnia 21 XI 1550 r. ${ }^{364} \mathrm{O}$ dalszym biegu tej sprawy akta kapitulne nie podają informacji. Zamieszki chłopskie pojawiły się również i na terenie należącego do biskupa krakowskiego księstwa siewierskiego, gdzie w Grójcu powstał zatarg w sprawie obciążeń poddanych nowymi ciężarami ${ }^{365}$.

Przeważająca część członków kapituły krakowskiej nie spotykała się $\mathrm{z}$ zarzutami gnębienia poddanych $\mathrm{w}$ posiadanych $\mathrm{z}$ nadania kościelnego majątkach. Wolny był od tego zarzutu i Stanisław Hozjusz, który nie tylko był daleki od krzywdzenia. kogokolwiek w swoich posiadłościach beneficjalnych, ale walczył i upominał się o lepsze traktowanie poddanych $\mathrm{w}$ innych dworach kościelnych, np. wraz ze szlachetnym prepozytem krakowskim Janem Przerębskim (późniejszym prymasem) upominał się o krzywdy poddanych w biskupim Jangrodzie, który dzierżawił Hieronim Szafraniec z Pieskowej Skały ${ }^{366}$. Bezpośrednim narzędziem ucisku poddanych $\mathrm{w}$ dobrach kapitulnych byli ustanowieni i popierani przez beneficjata faktorzy, którzy nieraz posuwali się do okrucieństw. Np. dnia 31 V 1549 r. nadeszła do kapituły krakowskiej wiadomość, że faktor w Grębałowie, wsi kapitulnej należącej wówczas do Feliksa Ligęzy, zabił faktora w Krzesławicach, majętności prepozyta bożogrobców

361 Tamże, k. 379 (17 X 1550).

362 Tamże, k. 386-387 (zapis z dnia 14 XI 1550).

363 Tamże, k. $389^{\prime}-390$.

${ }^{364}$ Tamże, k. 391', 393, 403; W. Urban, Chłopi wobec reformacji $w$ Matopolsce $w$ drugiej połowie XVI w., Krakow 1959, s. 79-80.

${ }^{365}$ Ep. Crac. 23, k. 202'-203 (r. 1545).

366 Cap. Crac. 4, k. 261'-262. 
miechowskich ${ }^{367}$. Tak samo Stanisław Hozjusz z przykrością dowiedział się, że w Łososkowicach, które mu kapituła pozostawiła na czas jego wyjazdu do władców habsburskich, wsi utrzymywanej przez niego wzorowo ${ }^{368}$, za rządów intruza Bartłomieja Gądkowskiego, archidiakona krakowskiego ${ }^{369}$, obsada dworska mordowała mieszkańców majątku kapitulnego, któremu tyle starań poświęcił. Bo oto w październiku $1549 \mathrm{r}$. karczmarz w Eososkowicach zabił kmiecia ${ }^{370}$, a w roku następnym sam faktor Stanisław w tychże Łososkowicach pozbawił życia człowieka ${ }^{371}$. Zbrodnia zabójstwa nie była w tym czasie zbyt surowo karana; o zaostrzenie kary za ten występek wytrwale walczył - jak wiadomo - w tym czasie Andrzej Frycz Modrzewski ${ }^{372}$. Morderca faktor został skazany na zapłacenie trzech grzywien i danie jednego kamienia wosku do kościoła parafialnego w Biórkowie. Zdarzyło się, że pleban z Harbutowic zabił parafianina (r. 1545). Było to zaraz po śmierci biskupa P. Gamrata ${ }^{373}$. Plebana wtrącono do karceru biskupiego. Gdy po niejakim czasie zabójca wrócił do swego kościoła, parafianie nie chcieli go przyjąć, chyba że otrzymają zapewnienie od władzy kościelnej, że ich duszpasterz nie był winien tej śmierci ${ }^{374}$.

Zabójcą był również jeden z kanoników krakowskich. Jak już wyżej wspomniano, Wilhelm Jarocki pobił i poranił $\mathrm{w}$ domu kapitulnym swego domownika, który wyrzucony na podwórko skonał na gnoju ${ }^{375}$. Wieść o tym poruszyła mieszczan krakowskich, samo pretorium upomniało się o zbrodniczo zgładzonego człowieka. Od niewielkiej kary śmiał Jarocki apelować do Rzymu ${ }^{376}$; zasadniczo występek ten nie został ukarany. Życie plebejusza nie przedstawiało wówczas większej wagi; tak było aż do końca Rzeczypospolitej szlacheckiej. Poddanych można było nawet darować. Np. Marcin Kromer otrzymał dnia 14 V 1546 r. trzech chłopów dla wsi Chotel w kustodii wiślickiej ${ }^{377}$.

Stosunek do służby w domach należących do członków kapituły krakowskiej był na ogół poprawny. Znalazły się jednak dwa wyjątki, które raczej potwierdzają regułę. Zebranie kapitulne karciło wszelką krzywdę

367 Tamże, k. 322 .

368 Tamże, k. 366-366'.

369 W październiku 1549 r., nie czekając na rezygnację Hozjusza zajętego poselstwem, optowali: na Łososkowice Bartłomiej Gądkowski, a na kamienicę Andrzej Czarnkowski. Kapituła jednak sprawę odłożyła do formalnego zrzeczenia się tych beneficjów przez Hozjusza (tamże, k. 335-336').

370 Tamże, k. 340.

371 Tamże, k. 371'.

372 W. Urban, Modrzewski (Frycz Modrzewski, Frycius Modrevius) Andrzej Piotr h. Jastrzębiec (ok. 1503-1572), [w:] PSB 21, s. 538-542.

373 Cap. Crac. 4, k. 91.

374 Tamże, k. 97.

375 Cap. Crac. 3, k. $303^{\prime}$.

376 Tamże, k. $330^{\prime}$.

377 Cap. Crac. 4, k. 153'. 
wyrządzoną przez prałatów czy kanoników swoim służebnikom. Wyżej wspomniany Jarocki przed swą śmiercią poranił służącego Stanisława z Bieńczyc - na szczęście nie śmiertelnie - pozostawiając go bez wypłaty. Kapituła zajęła się Stanisławem, czuwając nad tym, by uzyskał od spadkobierców wynagrodzenie za wyrządzone przez nieboszczyka

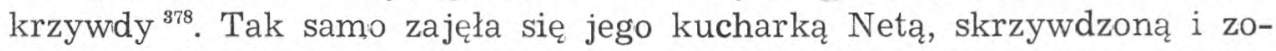
stawioną bez środków do utrzymania. Podobnie postępował ze służbą Jan Konarski, prepozyt kolegiaty św. Michała na Zamku. Swego służącego nie tylko nie wynagrodził, ale go obrabował doszczętnie i potem silnie pchnął ze schodów, tak że się mógł zabić ${ }^{379}$. Zwyczajną karą ze strony kapituły za złe postępki jej członków było pozbawienie refekcji codziennych i zakaz wstępu do kapitularza. Jan Konarski podlegał karze tylko jeden miesiąc ${ }^{380}$.

Około połowy XVI wieku w życie duchowieństwa - w większym, niż dawniej stopniu - wkradło się rozprzężenie obyczajów; wielu duchownych wbrew prawu celibatu zawierało związki małżeńskie, a jeszcze więcej grzeszyło niepowściągliwością. Pod tym względem najbardziej oddalili się od norm życia kapłańskiego w kapitule krakowskiej dwaj nepoci prymasa Jana Łaskiego: bratanek Jan, syn Jarosława Łaskiego, prepozyt gnieźnieński, i dalszy krewniak Wilhelm Jarocki. Pierwszy z nich zerwał z Kościołem i ulegalizował swe życie, zawierając małżeństwo. Drugi pozostał kanonikiem krakowskim, ale zupełnie porzucił kapłański styl postępowania, zaniedbywał obowiązki chórowe ${ }^{381}$, prowadził swój żywot w zaułku św. Piotra (wschodnie ramię ul. Poselskiej) w sposób nieobyczajny i gorszący ${ }^{382}$. Obok nich pozbawiony skrupułów w dziedzinie osobistej etyki był Andrzej Zebrzydowski ${ }^{383}$, a jego pokazowa gorliwość w obronie wiary była kierowana przesłankami polityczny$\mathrm{mi}^{384}$. Jan Konarski, prepozyt św. Michała na Zamku, po kilkuletnim pobycie we Włoszech na studiach był wraz ze Stanisławem Przeborowskim w r. 1538 karany przez kapitułę za gorszący, rozwiązły tryb ży$\operatorname{cia}^{385}$.

378 Tamże, k. 160'.

379 Tamże, k. $24-25$.

380 Tamże, k. 27.

381 Cap. Crac. 3 , k. $327^{\prime}$.

${ }^{382}$ Cap. Crac. 4 ,k. $165,173^{\prime}$.

${ }^{383}$ Cap. Crac. 3 , k. 186 ; 4, k. $174^{\prime}$.

${ }^{384}$ Notariusz aktów Andrzeja Zebrzydowskiego Wojciech Pruszkowski w nekrologu, jaki umieścił na końcu swych wpisów do ksiąg aktowych świadczy, że biskup umarł dnia 23 V 1560 r. we Wrześni, składając przed śmiercią wyznanie wiary i dzięlkując służbie, dla której był dobry, za wierność i oddanie (Ep. Crac. 28, k. 588-589). Cap. Crac. 3, k. 185-186, 192-192'.

${ }^{386}$ Notariusz Piotra Gamrata Bartłomiej Siekierzecki w nekrologu wpisanym na końcu aktów zmarłego biskupa, zanotował: Totus denique ad liberalitem et beneficentiam factus, quam ad prodigalitatem usque propemodum etiam erga inimi- 
Na 70 członków kapituły krakowskiej za czasów Hozjusza tylko pięciu wyżej wymienionych spotkało się z zarzutem niemoralnego prowadzenia się, za co byli upominani i karani. Ogólnie biorąc stan zachowania czystości życia w kapitule krakowskiej był dobry, choć słabość ludzka nie oszczędziła upadku niektórym jej członkom.

Trzeba jeszcze wspomnieć o marnotrawnym sposobie życia niektórych członków kapituły. Pod tym względem przewodził swej kapitule sam biskup Piotr Gamrat ${ }^{386}$. Utracjuszem był również Jan Łaski, prepozyt gnieźnieński, który od młodzieńczego wieku obsypywany przez stryja prymasa bogatymi beneficjami kościelnymi stale był pogrążony $\mathrm{w}$ długach ${ }^{387}$. Huczne biesiady i zgiełk muzyki rozlegał się w domu Feliksa Ligęzy, prepozyta przecławskiego, na ul. Kanoniczej 3, obok kamienicy podkanclerzego Samuela Maciejowskiego. Gdy Samuel został biskupem krakowskim, Ligęza wyniósł się z jego sąsiedztwa ${ }^{388}$. Kapituła gorszyła się postępowaniem Hieronima Rosborskiego, mieszkającego w „Domu Długosza” (ul. Kanonicza 25). Ten, zasłaniając się chorobą, opuszczał zebrania w katedrze ${ }^{389}$, co nie przeszkadzało mu brać udziału w dworskich przyjęciach. Miano go za symulanta, ale niesłusznie, bo istotnie choroba zabrała go $\mathrm{z}$ tego świata ${ }^{390}$. Szczyt nieodpowiedzialnej rozrzutności osiągnął Stanisław Przeborowski, mieszkający naprzeciw kościoła św. Marii Magdaleny (ul. Kanonicza 9). Robił on ogromne długi, nie mogąc ich spłacić ${ }^{391}$. Umarł jak ostatni nędzarz i został pochowany w lutym 1547 r. na koszt kapituły i biskupa S. Maciejowskiego ${ }^{392}$. Kapituła nie była również zadowolona, gdy jej członkowie zbytnio się wiązali z dworami magnatów i na nich brali różne zajęcia, jak np. Jakub Niemieczkowski, który przez całe życie kapłańskie służył Tarnowskim. Dlatego też dnia 6 X 1546 r. wydała ona specjalny dekret w tej sprawie.

Trzeba zauważyć, że ta piątka kanoników krakowskich, żądna wesołej, dworskiej kompanii, nie może przesłaniać rzeczywistego obrazu kapituły krakowskiej za czasów Hozjusza. Członkowie ówczesnej kapituły w przeważającej części byli oddani żmudnej pracy w służbie samej kapituły, diecezji i w dużej mierze dworu królewskiego dla dobra państwa polskiego. Ten rodzaj pracy niewątpliwie skłaniał ich do studiów przede wszystkim prawniczych, a konieczność częstego występowania w

cos exercuit (Ep. Crac. 21, k. 465-7). Nic dziwnego, że Gamrat zostawil po śmierci ogromne długi.

${ }^{387}$ Ep. Crac. 12 , k. $53-55 ; 13$, k. 28', 52.

388 Cap. Crac. 4, k. 100-100'. A Pankalla, Ligęza Feliks, h. Pótkozic (ok. 15001560), [w:] PSB 17, s. 315.

389 Cap. Crac. 5, k. 14.

390 Umarł przed 9 XI 1551 (tamże, k. 22).

391 Ep. Crac. 11, k. 313; Officialia Cracoviensia 59, s. 1513.

392 Cap. Crac. 4, k. 204'. 
roli mówców - do lektury tekstów klasycznych. Jest rzeczą oczywistą, że profesorowie i wykładowcy uniwersyteccy parali się komentarzami do Pisma św. i różnymi summami, tak teologicznymi, jak prawniczymi, a do ludzi oddanych studiom należeli - spoza uniwersytetu - tacy miłośnicy nauki, jak: Stanisław Hozjusz i Marcin Kromer.

$\mathrm{Na}$ koniec należy dodać kilka słów na temat wytrwania w powołaniu współczesnych Hozjuszowi prałatów i kanoników kapituły krakowskiej. Za czasów Hozjusza, tj. w latach 1540—1550, odeszło z niej sześciu jej członków, którzy opuścili stan duchowny. Tylko jeden z nich był wyświęconym kapłanem: Jan Łaski, syn Jarosława, prepozyt gnieźnieński, który porzucił katolicyzm i przeszedł na kalwinizm. Inni mieli tylko niższe święcenia, nie nakładające na nich specjalnych obowiązków, szczególnie celibatu, i nie zamykały im możności powrotu do stanu świeckiego. Do nich należeli: nepot biskupa P. Gamrata Mateusz Bal, który podobnie jak Łaski przyjął kalwinizm; nepot biskupa S. Maciejowskiego Jan Leżeński; ponadto trzech innych senatorskiego stanu: Stanisław Wolski, kustosz krakowski, później marszałek króla Zygmunta Augusta; Andrzej Myszkowski ${ }^{393}$, potem kasztelan lubelski, związany z małopolskim ruchem innowierczym, i Mikołaj Ossoliński ${ }^{394}$.

Powyższy obraz życia kapituły krakowskiej u progu najbardziej krytycznego okresu Kościoła polskiego, jaki wypadł na wiek XVI, świadczy o tym, że mimo pewnych ujemnych rysów, których auțor niniejszej pracy celowo nie ukrywał, zachowała należyty poziom życia kościelnego, zwartość i wierność powołaniu, odznaczała się stałością w wierze, broniąc się przed infiltracją nowych dogmatów i obcych nauce Kościoła -norm moralnych.

Rekrutująca się z szeregów szlachty całego terytorium Polski krakowska kapituła nie ustrzegła się wad i przywar cechujących ówczesną społeczność, co zaznaczyło się w życiu niektórych jej członków, lecz w znakomitej większości miała poczucie tego, co dobre i szlachetne. W walce $\mathrm{z}$ zagrożeniem diecezji przez nowatorskie innowierstwo była najsilniejszym bastionem wiary i wzorem oddania Kościołowi katolickiemu.

\section{STANISEAW HOZJUSZ NA USEUGACH KAPITUEY KRAKOWSKIEJ}

Hozjusz jako kanonik krakowski miał obowiązek współpracować z kapitułą i służyć jej różnorodną pomocą według swoich możliwości i zdolności. Po wejściu jednak do grona kapitulnego nie od razu mógł się s. 368 .

${ }^{393}$ H. Kowalska, Myszkowski Andrzej z Mirowa, h. Jastrzębiec, [w:] PSB 22,

${ }^{394}$ Mikołaj Ossoliński był kanonikiem krakowskim w 1. 1550-58. (Cap. Crac. 4, k. $369-370^{\prime} ; 5$, k. $\left.328^{\prime}\right)$. 
podjąć tego zadania ze względu na swój związek z dworem królewskim, gdzie pełnił bardzo odpowiedzialną rolę sekretarza koronnego; ten dwór przygotowywał się właśnie w tym czasie do wyjazdu poza Kraków, Hozjusz zaś otrzymał polecenie towarzyszenia królowi. Pierwszy raz Hozjusz pojawił się w kapitularzu katedry krakowskiej dnia 27 II 1540 r., gdzie wobec zgromadzonej kapituły został przyjęty na prebendę szczytnicką ${ }^{395}$, a zaraz potem wszczął starania, ażeby jeszcze przed wyjazdem otrzymać przydział jakiejś kamienicy kapitulnej na mieszkanie, co mu się udało i dnia 22 IV 1540 r. objął w posiadanie kứrię przy ul. Kanoniczej, dzis̉ oznaczoną $\mathrm{nr} 8^{396}$. Po raz ostatni przed opuszczeniem Krakowa Hozjusz przyszedł do kapitularza dnia 25 IV 1540 r. wraz ze swoim przyjacielem Samuelem Maciejowskim, wówczas biskupem chełmskim, gdzie był świadkiem, jak jego ówczesny przełożony w kancelarii królewskiej zrezygnował z kanonii krakowskiej na rzecz swego siostrzeńca Jana Leżeńskiego ${ }^{397}$. Niedługo potem Hozjusz wyjechał z dworem królewskim na przeciąg dwóch lat do Wilna. Zajęcia w kancelarii królewskiej tak bardzo go w tym czasie absorbowały, że już więcej ani w roku 1540, ani w r. 1541 nie pokazał się na zebraniu krakowskiej kapituły. Po tak długiej przerwie Hozjusz pojawił się wśród grona kapitulnego dopiero 23 VI 1542 r. $^{398}$

Odtąd aż do końca r. 1542 gorliwie uczęszczał na zebrania kapituły. W przeciągu tego półrocza aż 20 razy zapisana była jego obecność w kapitularzu ${ }^{399}$. Brał udział w obradach, na których dokonywały się zmiany wśród prałatów i na prebendach kapitulnych, omawiano sprawy prestymoniów ii ogólne sprawy gospodarcze. Kapituła dużo wysiłków wkładała w złagodzenie zatargów między Andrzejem Czarnkowskim a Janem Naropińskim, a także między tym ostatnim a Benedyktem Izdbieńskim. Hozjusza czekało w tym roku bardzo trudne i delikatne zadanie załatwienia pretensji mieszkańców regencji kapitulnej w Pabianicach z powodu wyrządzonych krzywd w czasie długoletniego zarządu tym majątkiem kapituły przez Samuela Maciejowskiego, który wówczas przesunął

395 Cap. Crac. 3, k. 247'.

396 Cap. Crac. 4 , k. 249-250, 253.

397 Cap. Crac. 3 , k. 253-253'.

398 Cap. Crac. 3, 337'. W liście do Dantyszka z dnia 10 III 1540 Hozjusz pisał: Vilnam cogitat $S$. Maiestas regia post dies plus minus trignita; cam comitari decretum est. Hozjusz, towarzysząc dworowi królewskiemu, przebywał przez cały czas we Wilnie, z wyjątkiem dwóch wypadów: jednego do Kowna (Hos. eplae I, nr 70, $4 \mathrm{X} 1540$, s. 93) i drugiego do Prus w czasie powrotu króla do Krakowa (tamże, $\mathrm{nr} 112,13$ VI 1542, p. 2). Hozjusz wracał do Krakowa przez Sandomierz (tamże, nr 112,13 VI 1542 , s. $125-126)$.

${ }_{399}$ W roku 1542 Hozjusz był obecny na posiedzeniu krakowskiej kapituły w następujących dniach: 23 VI 1542 (Cap. Cac. 3, k. 377); 8 VII (378-378'); 14 VII (378); 21 VII (380); 23 VII (380'); 28 VII (382); 4 VIII (384); 11 VIII (384'); 18 VIII $\left(385^{\prime}\right) ; 25$ VII (386); 30 IX (388'); 2 X (389); 6 X (390); 7 X (390-390'); 11 X (391'); 10 XI (392); 5 XII (394-395); 7 XII (395-395'); 22 XII (396); 29 XII (398). 
się z biskupstwa chełmskiego na płockie. Mieszkańcy Pabianic nie tylko oskarżyli, ale i żądali wynagrodzenia szkód uczynionych przez faktorów biskupa S. Maciejowskiego. Do omówienia tej sprawy z pokrzywdzonymi i pośrednictwa między nimi a biskupem Maciejowskim kapituła postanowiła wybrać przyjaciół biskupa w nadziei, że oni będą mogli najłatwiej porozumieć się $\mathrm{w}$ tej sprawie $\mathrm{z}$ wincekanclerzem Państwa, a zarazem biskupem płockim. Deputatami w sprawie pabianickiej zostali wybrani przez kapitułę dnia 11 X 1542 r.: Benedykt Izdbieński, kantor krakowski, oraz kanonicy krakowskiej kapituły St. Hozjusz i Stanisław Przeborowski ${ }^{400}$. Porozumiewanie się z biskupem. S. Maciejowskim było o tyle ułatwione, że oskarżony przez mieszkańców Pabianic dygnitarz bez trudu był dostępny, bo mimo piastowania godności biskupiej w dalekim Płocku - jako wicekanclerz Państwa mieszkał przede wszystkim w Krakowie, w domu ,św. Grzegorza” (ul. Kanonicza 1) i przez wymienionych wyżej przyjaciół, a obecnie deputatów do sprawy pabianickiej, był często odwiedzany ${ }^{401}$. Dokonane krzywdy trzeba było sprawdzić na miejscu w Pabianicach. Dlatego St. Hozjusz z kolegami deputatami wybrał się w podróż do okręgu pabianickiego, wziąwszy ze sobą wykaz krzywd zadanych tamtejszej ludności przez ojca biskupiego Bernarda Maciejowskiego, kasztelana lubelskiego. Na żądanie deputatów kasztelan Bernard zgodził się jechać wraz z nimi do Pabianic, gdyż wizytatorowie - rozsądzając sprawę pretensji mieszkańców kapitulnej włości - pragnęli wysłuchać zdania i strony przeciwnej ${ }^{402}$. Sprawa wynagrodzenia za szkody wyrządzone $w$ Pabianicach za regencji S. Maciejowskiego ciągnęła się aż do czasu przyjścia biskupa Samuela Maciejowskiego na stolicę krakowskią (r. 1546) ${ }^{403}$.

Hozjusz z pewnością współczuł przyjacielowi Samueolowi Maciejow-

${ }^{400}$ Po śmierci regenta Mikołaja Zamojskiego, kanonika krakowskiego, Samuel Maciejowski jako kanonik gnieźnieński i krakowski, wziął ad kapituły krakowskiej jej majątek Pabianice w 3-letnią arendę (Cap. Crac. 3, k. 81'-84). Jako nowy regent zobowiązał się nie podwyższać ciężarów poddanym, nie używać niezwykłych kar i nie pozwolić oficjalistom w komitacie pabianickim nękać ludności (tamże, k. 99'-100). Rządy w Pabianicach miał S. Maciejowski utrudnione, bo niedługo po zawarciu umowy miasto się spaliło. Kapituła przystąpiła do odbudowy zniszczonego pożarem kościoła, a dźwignięcie $\mathrm{z}$ ruiny dworku pabianickiego należało do regenta, tj. do Samuela (tamże, k. 109'). Maciejowski oddał użytkowanie Pabianic $w$ ręce rodziny, a chcąc ją jak najwięcej wspomóc, odnowił kontrakt dzierżawy na dalsze 3-lecie (tamże, k. 108, 109'). Zostawszy biskupem chelmskim zatrzymał bezprawnie Pabianice, co stało się źródłem nowych kkłopotów kapituły (tamże,

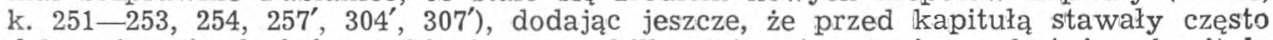
delegacje mieszkańców Pabianic przez kilka lat natarczywie molestując kapitułę skargami i żalami za krzywdy wyrządzane przez zarząd rejencji. Sam Maciejowski ustąpił z Pabianic 18 VI 1541 (tamże, k. 316).

${ }^{401}$ Benedykt Izdbieński i Samuel Maciejowski byli niegdyś osobistymi sekretarzami Piotra. Tomickiego, a ich kolegami na dworze tegoż biskupa był Hozjusz i St. Przeborowski (Ep. Crac. 11, k. 241').

402 Cap. Crac. 3, k. 254, 391'.

${ }^{403}$ Cap. Crac. $4, k .19^{\prime}-20$. 
skiemu w jego tak trudnej sytuacji, zawinionej nie przez niego, ale przez jego rodzinę. Nad jej rozwojem Hozjusz czuwał nieustannie, bo sprawa Pabianic - własności kapitulnej - mogła być załatwiana tylko na jej zebraniach, a szczęśliwą okolicznością stało się to, że regentem Pabianic został scholastyk Andrzej Czarnkowski, bliski przyjaciej S. Maciejowskiego i dzielny administrator w sprawach gospodarczych. Czarnkowski, mający łatwy dostęp do wicekanclerza Samuela, podjął się zaspokojenia pretensji mieszkańców regencji pabianickiej. Sprawa była o tyle trudna - jak widać z jej przebiegu - że biskup płocki trzymáł stronę kierowanych przez jego rodzinę. Dnia 20 II 1545 r. Hozjusz z A. Czarnkowskim złożyli sprawozdanie z rozmów prowadzonych z biskupem S. Maciejowskim w sprawie szkód wyrządzonych przez jego rodzinę w Pabianicach ${ }^{404}$.

Oprócz sprawy pabianickiej Hozjusz głęboko przeżywał jeszcze drugi zatarg kapituły, tym razem ze St. Tarłą, biskupem przemyskim, który mimo że przez munus consecrationis episcopalis stracił prawo do posiadania kamienicy kapitulnej (ul. Kanonicza 3) i prestymonium w Witkowicach pod Krakowem, nie chciał tych dóbr kapitulnych opuścić. Kapituła używała różnych sposobów, ażeby odzyskać swą własność ${ }^{405}$, nawet odwoływała się do Rzymskiej Kurii, posyłając tam 15 V 1544 r. Filipa Padniewskiego ${ }^{406}$, jednak St. Tarło aż do swojej śmierci, która nastąpiła w jesieni 1544 r., ani domu, ani Witkowic nie oddał ${ }^{407}$. Hozjusz w tym czasie pragnął doprowadzić do pokojowego załatwienia sprawy tak w r. $1543^{408}$, w którym do lipca stale bywał na zebraniach kapituły ${ }^{409}$ (w tym roku objął urząd wielkiego sekretarza koronnego i przyjął święcenia kapłańskie), jak i w r. $1544{ }^{410}$. Dnia 18 XII 1544 r. St.

404 Tamże, k. $59^{\prime}-60$.

405 Cap. Crac. 3 , k. $303,390^{\prime}, 415,426$.

406 Cap. Crac. 4, k. 13, 14.

${ }_{407}$ Tamże, k. 32, 46, 47, 47'; Ep. Crac. 22, k. 278.

408 Cap. Crac. 3 , k. $425 ; 4$, 1.2.

409 W r. 1543 Hozjusz był obecny na posiedzeniach kapituły krakowskiej w następujących dniach: 5 I 1543 (Cap. Crac. 3, k. 397'); 12 I (399); 19 I (399'); 26 I $\left(399^{\prime}\right) ; 3$ II $(400) ; 6$ II $\left(400^{\prime}\right) ; 9$ II $\left(401^{\prime}\right) ; 20$ II (405); 23 II (406); 16 III (408); 19 III

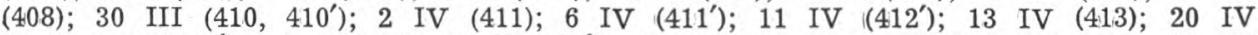
(414); $9 \mathrm{~V}\left(415^{\prime}\right) ; 10 \mathrm{~V}(416) ; 11 \mathrm{~V}\left(416^{\prime}\right) ; 12 \mathrm{~V}(419) ; 18 \mathrm{~V}(420) ; 1 \mathrm{VI}(421) ; 15 \mathrm{VI}$ (422); 18 VI (420); 26 VI (424'); 3 VII (425); 6 VII (425); 12 VII (425'). Przy końcu lipca 1543 r. wybuchła w Krakowie zaraza. Dnia 3 VIII zmarł notariusz kapitulny Jan z Wojsławic (Cap. Crac. 4, k. 1), a 9 VIII kapituła krakowska opłakiwała śmierć swego archidiakona Jerzego Myszkowskiego (tamże, 1', 2). Hozjusz, jako wysoki urzędnik państwowy, wyjechał z otoczeniem królewskim z Krakowa i skienował się do Sandomierza, następnie do Zawichostu; 20 dni przebywał w swej parafii w Gołębiu i tam dostał od kanclerza list z poleceniem, by wracał do króla przebywającego w Nowym Korczynie, skąd z królestwem udał się do Dobrowody, Wielowieży, Połańca. Dalszy pobyt trwający 40 dni wypadł na Sandomierz. Stąd król wybierał się na sejm do Piotrkłowa, lecz ten wyjazd musiał odłożyć (Hos. eplae I, $\mathrm{nr} 139$, s. 141-142). Ostatni list z Sandomierza Hozjusz napisał do Dantyszka 16 XII 1543 (Hos. eplae, I, nr 149, s. 150).

$410 \mathrm{Z}$ początkiem r. 1544 Hozjusz był w Piotrkowie $(20$ I - Hos. eplae I, s. 
Hozjusz wystąpił na zebraniu kapituły z zawiadomieniem,.że niedawno zmarły biskup St. Tarło zlecił wykonanie swego testamentu biskupowi S. Maciejowskiemu, a króla obrał za opiekuna spełnienia swej ostatniej woli ${ }^{411}$. Ponadto Hozjusz na forum kapitulnym oświadczył, że Maciejowski, jako egzekutor testamentu biskupa St. Tarły, oddaje wszystkie rzeczy zatrzymane przez zmarłego w Witkowicach krakowskiej kapitule. Zarząd Witkowic mógł już teraz bez przeszkody wykonywać Maciej Zieleński ${ }^{412}$, a dom przy ul. Kanoniczej 3 objął Feliks Ligęza ${ }^{413}$.

W r. 1545, który był ostatnim w życiu prymasa i biskupa krakowskiego Piotra Gamrata, Hozjusz przebywał stale w Krakowie. Na zebraniach kapituły krakowskiej był obecny $2 \dot{5}$ razy ${ }^{414}$. W tym roku wspaniale odnowił swój dom kapitulny przy ul. Poselskiej 12, tak że kapituła z wdzięczności zwolniła go od płacenia przypadającej mu w r. 1545 taksy od tegoż domu ${ }^{415}$. Także w tym roku przypadło na Hozjusza, jako kanonika krakowskiego, wiele obowiązków. Wykańczał wyżej wspomnianą sprawę wynagrodzenia krzywd wyrządzonych mieszkańcom Pabianic, w lutym upominał kaznodzieję Leonarda za jego zbyt reformistyczne kazania, w kwietniu zaś przeprowadzał inkwizycję w szeregu przesłuchań co do prawowierności członków kapituły krakowskiej.

W okresie letnim - między 11 VII a 21 VIII 1545 r. - Hozjusz wyjechał z Krakowa. Gdy wrócił, prymas Gamrat był umierający. Smierć nastąpiła 27 VIII i Hozjusz wraz z kapitułą zajął się pogrzebem kra-

151-152), a ostatni list $\mathrm{z}$ Piotrkowa został przez niego wysłany dnia 15 III $1544 \mathrm{r}$. (Hos. eplae I, $\mathrm{nr} 155$, s. $154-155$ ). Następnie wyjechał do Krakowa, gdzie zamieszkał w nowej rezydencji danej mu przez kapitułę dnia 7 V 1543 r. przy ul. Poselskiej 12 (Cap. Crac. 3, k. 418-418'). Dnia 24 III 1544 pierwszy raz po przyjeździe pokazał się na zebraniu kapituły krakowskiej (Cap. Crac. 4, k. 11) i dalej pozostawał w Krakowie. Był tu jeszcze 14 IV 1544 r., ale 10 maja tegoż noku przebywał już w Malborku (Hos. eplae I, s. 155-156). Potem pnzeniósł się do Gdańska (tamże, 156-158), a w tym czasie - podczas jego nieobecności w kapitularzu kapituła krakowska dnia 16 i $23 \mathrm{~V}$ przyłożyła swe pieczęcie do akt darowizny dziesięcin danych mu przez biskupa Gamrata (Cap. Crac. 4, k. 15 i 17'). Dalsza podróż dyplomatyczna Hozjusza prowadziła do Brześcia nad Bugiem. W kapitule krakowskiej znów się pojawił dnia 30 X 1544 r. (tamże, k. 37 i 38) i odtąd dłuższy czas przebywał w Krakowie. Jego obecność na zebraniach kapitulnych w końcu tego roku jest zanotowana: 14 XI 1544 (Cap. Crac. 4, k. 37-38); 21 XI (39); 22 XI (39); 26 XI (39); 28 XI (39); 2 XII (44'); 9 XII (45'); 18 XII (46); 19 XII (46');

411 Cap. Crac. 4 , k. 46.

412 Tamże, k. 22.

413 Tamże, k. 50-50'.

${ }_{414} \mathrm{~W}$ r. 1545 Hozjusz był obecny na posiedzeniach kapituły krakowskiej w następujących dniach: 2 I (Cap. Crac. 4, k. 48-48'); 4 I $\left(49^{\prime}\right) ; 3$ II $\left(52^{\prime}\right) ; 6$ II $\left(54^{\prime}\right)$; 9 II (55); 10 II (56); 14 II $\left(58^{\prime}-59\right) ; 14$ II (59); 20 II $\left(59^{\prime}-60\right) ; 6$ III $\left(61^{\prime}\right) ; 20$ III $\left(69^{\prime}\right) ; 10$ IV $\left(64^{\prime}\right) ; 24$ IV $(69) ; 27$ IV $\left(71^{\prime}\right) ; 7 \mathrm{~V}(73) ; 9 \mathrm{~V}\left(73^{\prime}\right) ; 13 \mathrm{~V}\left(74^{\prime}\right) ; 20 \mathrm{~V}$ (77); 6 VI $\left(79^{\prime}\right) ; 26$ VI $\left(80^{\prime}\right) ; 27$ VI $\left(82^{\prime}-83\right) ; 4$ VII $(83-84) ; 11$ VII $\left(84^{\prime}\right)$; 21 VIII

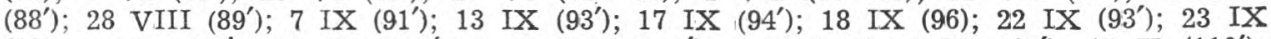
(98); 25 IX $\left(99^{\prime}\right) ; 30$ IX $\left(101^{\prime}\right) ; 1$ X $\left(102-102^{\prime}\right) ; 5 \mathrm{X}(105) ; 8 \mathrm{X}\left(107^{\prime}\right) ; 14 \mathrm{X}\left(110^{\prime}\right)$; $16 \mathrm{X}\left(111^{\prime}\right) ; 17 \mathrm{X}\left(114^{\prime}\right) ; 30 \mathrm{X}(115) ; 6 \mathrm{XI}$ (116); $9 \mathrm{XI}(117) ; 13 \mathrm{XI}(118) ; 16 \mathrm{XI}$ (119'); 21 XI (120); 27 XI (122'); 11 XII (123'); 18 XII (124). 415 Cap. Crac. 4, k. 58-59. 
kowskiego biskupa. Gamrata złożono do grobu dnia 16 IX $^{416}$, a w następnym dniu po egzekwiach (17 IX) Hozjusz zasiadł wraz z kapituła do wyboru administratora diecezji sede vacante, którym został scholastyk Andrzej Czarnkowski ${ }^{417}$. Na kapitułę spadł obowiązek wyboru w krótkim czasie nowego pasterza krakowskiej diecezji. W myśl ówczesnej praktyki należało uprzednio omówić z królem termin elekcji biskupiej. Przy tej okazji wręczano monarsze pewną sumę pieniężną w formie gratyfikacji, uważana za daninę dla państwa ze strony Kościoła, który mało partycypował w wydatkach na cele publiczne. Delegaci kapituły przy spotkaniu z królem omawiali termin wyboru nowego biskupa, nie dotykając bynajmniej spraw personalnych. Ponieważ skarb kapituły krakowskiej był po pogrzebie biskupa Gamrata zupełnie pusty, zwrócono się do najlepszego gospodarza, jakim był w kapitule Hozjusz, o pożyczkę 100 dukatów na podarunek dla króla, a 50 dukatów dla królowej. Jeśli chodziło o dar dla królowej, odezwały się głosy sprzciwu ze strony niechętnych Bonie członków kapituły. Sprawą tą zajmowano się w dniach 22 i 23 IX 1545 r. ${ }^{418}$ Hozjusz pieniędzy pożyczył. Termin wyboru nowego biskupa krakowskiego najpierw ustalono na $1 \mathrm{X}^{419}$, lecz później przesunięto na dzień 14 X 1545 r. ${ }^{420} \mathrm{Na}$ polecenie królewskie krakowską stolicę biskupią otrzymał Samuel Maciejowski, który jeszcze przed zatwierdzeniem swego wyboru przez Stolicę Apostolską wbrew prawu kościelnemu - objął 25 X 1545 r. zarząd dóbr stołowych biskupstwa krakowskiego. Administrator diecezji A. Czarnkowski z upoważnienia biskupa elekta krakowskiego wziął pod swą opiekę majątki biskupie ${ }^{421}$. Również niezgodne z kanonami Kościoła było uroczyste powitanie S. Maciejowskiego w dniu 30 X 1545 r. przez kapitułę krakowską, mimo że do papieskiego zatwierdzenia nowego elekta było jeszcze daleko ${ }^{422}$. Objęcie przez biskupa S. Maciejowskiego dóbr mensae episcopalis w krakowskiej diecezji postawiło przed kapitułą ciężki problem dokonania podziału dochodów biskupstwa między masą spadkową a nowym biskupem-elektem krakowskim, problem wprost groźny, zważywszy że zmarły Gamrat zostawił ogromne długi, dochodzące do sumy 50 tysięcy złotych. Do tego został on pochowany na koszt kapituły, która na opędzenie kosztów pogrzebu pożyczyła od królowej Bony 7 tysięcy

${ }^{416}$ Tamże, k. 94.

417 Tamże, k. 95-95'.

418 Tamże, k. 98.

419 Tamże, k. 96'.

420 Tamże, k. 110'-111'.

${ }^{421}$ Tamże, k. 112'-113. Breve apostolskie translationis Samuela Maciejowskiego z biskupstwa płockiego na krakowskie dotarło do Krakowa dopiero 3 IV 1546 (Cap. Crac. 4, k. 144).

${ }_{422}$ Cap. Crac. 4, k. 115. Do Samuela jako elekta krakowskiego przemówil $30 \mathrm{X}$ $1545 \mathrm{w}$ imieniu kapituły krakowskiej Hozjusz, wysławiając jego cnoty i piękne obyczaje (Hos. eplae I, nr 205, s. 198-199). 
złotych, dając jej w zastaw srebro ${ }^{\circ}$ Gamratowe ${ }^{423}$. Zatroskana kapituła wyznaczyła dnia 9 XI delegatów, którzy mieli pójść do biskupa-elekta w sprawie podziału dochodów. Należeli do nich: administrator A. Czarnkowski, kantor Benedykt Izdbieński (już wtedy będący nominatem kamienieckim), Piotr Myszkowski i sam Hozjusz ${ }^{424}$. Oprócz tego wybrano Hozjusza na inspektora, by czuwał nad pilnym zadaniem spisania rzeczy pozostałych po śmierci Gamrata ${ }^{425}$. Doktor Hozjusz podjął się tego chętnie przez wzgląd na przyjaźń i protekcję, jakiej doznawał od zmarłego biskupa oraz z wdzięczności za dobrodziejstwa od niego otrzymane ${ }^{426}$. W sprawie długów pozostałych po Gamracie zwrócił się do kapituły i sam król,za pośrednictwem Jana Osieckiego, podkomorzego ziemi krakowskiej. Z wierzycieli najbardziej natarczywym i najgroźniejszym był Seweryn Boner z Balic, kasztelan i starosta biecki, żupnik, burgrabia i wielkorządca zamku wawelskiego, który dnia 6 XI 1545 r. zażądał od kapituły wykonującej testament zmarłego biskupa Gamrata sumy 6 tysięcy złotych ${ }^{427}$. Kapituła nie była jednak w stanie zaspokoić pretensji Bonera. Prócz kłopotu z masą spadkową po Gamracie, kapituła krakowska miała jeszcze inne zmartwienie. Mianowicie chodziło o to, że nowo powstające wsie (in cruda radice) nie poczuwały się do obowiązku płacenia danin kościelnych, tak jak to czyniły dawniej istniejące. Kapitule zależało na tym, żeby $\mathrm{w}$ tej sprawie interweniował $\mathrm{u}$ króla biskup S. Maciejowski, podkanclerzy, a także i Jan Tarnowski, kasztelan krakowski. Do negocjacji z tymi dygnitarzami wybrano Hozjusza ${ }^{428}$, kapłana bliskiego biskupowi, by zainteresował tą sprawą wicekanclerza, a także by się odniósł do sąsiadującego z jego kamienicą (in postico) kasztelana Jana Tarnowskiego. W międzyczasie Hozjusz wraz z innymi zajmował się rewizją dokumentów dotyczących kanonizacji św. Jacka ${ }^{429}$.

W drugiej połowie r. 1545 od czasu śmierci Piotra Gamrata Hozjusz pozostawał stale w Krakowie, brał udział we wszystkich uroczystościach kościelnych i posiedzeniach kapitulnych ${ }^{430} \mathrm{i}$ ciesząc się wyborem przyjaciela na krakowską stolicę biskupią oczekiwał jego zatwierdzenia przez Stolicę Apostolską. Dopiero 3 IV 1546 r. zostało odczytane na posiedzeniu kapituły breve rzymskie przenoszące Samuela Maciejowskiego $\mathrm{z}$ Płocka na biskupstwo krakowskie ${ }^{431}$. W dniu następnym (4 IV), w nie-

${ }^{423}$ Cap. Crac. 4, k. 91', 93, 97, 102', 117-117'. Por. I. Polkowski, Spadek po prymasie arcybiskupie gnieznieńskim $i$ biskupie krakowskim Piotrze Gamracie, [w:] Rozpr. Wydz. Filoz.-Historycznego AU 21 (1888) s. 1 -23.

${ }_{424}$ Cap. Crac. 4, k. 117, 118-119.

425 Tamże, k. 123'.

${ }_{426}$ Tamże, k. 102', 115.

427 Tamże, k. 116-116'.

428 Tamże, k. 118.

${ }_{429}$ Tamże, k. 114'.

430 Por. przypis 414.

431 Cap. Crac. 4. k. 144 
dzielę „Laetare" Hozjusz wziął udział w uroczystym ingresie biskupa Maciejowskiego do katedry krakowskiej ${ }^{432}$.

Z chwilą wyboru Samuela Maciejowskiego na biskupa krakowskiego wzrosła w kapitule rola jego ulubionego kanonika, jakim był Stanisław Hozjusz. Ilekroć kapituła posyłała do biskupa Samuela jakąkolwiek deputację, z reguły wybierała na jednego z jej członków również i doktora Hozjusza. Niedługo po ingresie 13 IV 1546 r. kapituła uchwaliła złożyć biskupowi Maciejowskiemu podziękowanie za okazaną pomoc przy wykonanywaniu testamentu zmarłego Piotra Gamrata i do przekazania wyrazów wdzięczności wybrała delegację, w skład której wchodził Hozjusz wraz z dziekanem St. Borkiem, scholastykiem A. Czarnkowskim i referendarzem J. Uchańskim ${ }^{433}$. Jeszcze trzy razy w r. 1546 Hozjusz chodził do biskupa Maciejowskiego jako deputat kapituły: 4 czerwca towarzyszył St. Borkowi, A. Czarnkowskiemu i kanclerzowi biskupiemu J. Przerębskiemu ${ }^{434}$, w dniu 3 XII szedł w delegacji z J. Przerębskim, nowym kanclerzem A. Przecławskim i Marcinem Kromerem ${ }^{435}$; wreszcie w Starym Roku kapituła wysłała do biskupa 3-osobową deputację, w której Hozjuszowi dodano referendarza J. Uchańskiego i kanclerza biskupiego A. Przecławskiego ${ }^{436}$. Deputaci mieli instrukcje ustne, podane przez kapitułę, dlatego nie jest znana treść ich poselstwa.

W drugiej połowie 1546 r. St. Hozjusz odegrał szczególną rolę przy wyborze kaznodziei katedralnego. Dotychczasowym kaznodzieją był Leonard Altimontanus (czyli Wyszogrodzki), noszący także nazwisko Słończewski, którego - jak wyżej wspomniano - Hozjusz i Jakub z Kleparza upominali $\mathrm{z}$ powodu wygłoszonego w kościele Mariackim kazania w duchu skrajnej krytyki Kościoła i niektórych zasad wiary, krytyki graniczącej z luterskimi tezami. Mimo tego upomnienia, na żądanie szlachty podolskiej został on mianowany przez Zygmunta Starego biskupem kamienieckim i dnia 20 VIII 1546 r. zatwierdzony przez Stolicę Apostolską. W Kamieńcu był biskupem rezydującym, co się w tych czasach prawie nie zdarzało, i gorliwie spełniał obowiązki biskupie w swej ubogiej diecezji. Będąc jeszcze w Krakowie, Leonard po otrzymaniu konfirmacji rzymskiej złożył dnia 1 X 1546 wobec kapituły rezygnację ze stanowiska kaznodziei katedralnego i zarazem wskazał na swego następcę bakałarza Stanisława z Łowicza, kaznodzieję w kościele św. Szczepana. Kapituła jednak zawiesiła swój sąd w tej sprawie i dnia $6 \mathrm{X}$ po-

432 Tamże, k. $144-144^{\prime}$. Przemówienie Samuela Maciejowskiego, wygłoszone w czasie ingresu (4 IV 1546 r.), było ułożone przez Hozjusza (Hos. eplae I, nr 216, s. $208-209$ ).

433 Tamże, k. 147.

${ }_{434}$ Tamże, k. 160.

435 Tamże, k. 191.

436 Tamże, k. 195. 
prosiła Leonarda, ażeby zadania kaznodziei spełniał jeszcze do końca roku ${ }^{437}$. Kapituła ustanowiła tę zwłokę, mając na uwadze, że władzy do głosowania Słowa Bożego udzielał biskup i że bez jego wiedzy nie mogła sama przystąpić do wyboru nowego kaznodziei w swej katedrze. Jako łącznika między kapitułą a biskupem Maciejowskim wybrano St. Hozjusza, który miał omówić z władzą diecezjalną wybór dobrego, a zarazem gwarantującego wierność wierze rzymskiego Kościoła predykatora. W połowie grudnia 1546 r. Hozjusz wyjawił wobec zebranej kapituły decyzję (mentem) biskupa, że nowym kaznodzieją katedralnym ma być Łukasz Aquilinus, głoszący dotąd kazania w kościele Mariackim w Krakowie, który od Nowego Roku 1547 miał objąć nowe obowiązki na Wawelu ${ }^{438}$. Eukasz Aquilinus został dnia 18 XII zaproszony do kapitularza, gdzie kapituła uroczyście go przyjęła jako zwyczajnego kaznodzieję katedralnego ${ }^{439}$.

W ciągu r. 1546 ciągle odzywała się nie załatwiona sprawa spadku po nieboszczyku Piotrze Gamracie. Sprawa była trudna, bo zmarły biskup krakowski, a zarazem arcybiskup gnieźnieński, był człowiekiem szczerym i w swej łaskawości rozrzutnym. Nie wystarczały mu na jego wydatki dochody $\mathrm{z}$ obu diecezji. Zalegał także $\mathrm{z}$ wypłatami dla swoich domowników i służby. Niewiele zostało po nim gotówki. Jak już wyżej wspomniano, kapituła zaciągnęła u królowej Bony dużą pożyczkę ( 7 tys. zł) na wyprawienie pogrzebu, dając jej w zastaw srebro Gamratowe ${ }^{440}$. Pretensje do spadku po zmarłym biskupie zgłosiła ogromna liczba petentów ${ }^{441}$, często stawiając żądania bezpodstawne, kłamliwe lub lekkomyślnie zawyżone. Kapituła w pierwszym rzędzie spłacała służbę i najbardziej potrzebujących wierzycieli, lecz w końcu zabrakło jej pieniędzy. Wystąpił przeciw niej na nowo Seweryn Boner z Balic, który w roku poprzednim $(6 \mathrm{XI})$ zgłosił po raz pierwszy swe pretensje ${ }^{442}$. Boner ponowił swe żądania w tym dniu (26 VI 1546 r.) ${ }^{443}$, w którym kapituła ogłosiła niewypłacalność długów zmarłego biskupa ${ }^{444}$. Mimo to członkowie kapituły wiedzieli, że Boner nie ma zamiaru ustąpić i dlatego w je-

437 Tamże, k. 180'.

438 Tamże, k. 184.

439 Tamże, k. 194. Kapituła krakowska już przedtem zwróciła uwagę na Łukasza. Gdy otrzymał promocję na bakałarza teologii, na zebraniu kapitulnym odbytym dnia 20 VI 1544 r. uchwalono dać mu z tej okazji gratyfikację $\mathrm{w}$ wysolkości 6 florenów (Cap. Crac. 4, k. 22). Być może, że był wychowankiem szkoły zamkowej. Łukasz pochodził z Orłowa (Ep. Crac. 28, k. 407).

${ }_{440}$ Por. wyżej przypis 423.

441 Ingens turba familiarum (Cap. Crac. 4, k. 99').

442 Cap. Crac. 4, k. 116-116'.

443 Tamże, k. 162'.

${ }^{444} \mathrm{Ni}$ il collectum, omnia absumpta, exacta, proinde nihil est, unde solutio fieret (Cap. Crac. 4, k. 162-163). 
sieni (24 IX 1546 r.) postanowiono wybrać delegata do załatwiania tej trudnej sprawy; wybór padł na Stanisława Hozjusza ${ }^{445}$. Kilka dni później (30 IX) zebrała się przy katedrze krakowskiej jesienna kapituła generalna, na której głównym tematem obrad było omawianie pretensji Seweryna Bonera ${ }^{446}$. Szukano sposobu załatwienia tej sprawy, czy to uciekając się do pośrednictwa królowej Bony ${ }^{447}$, czy to starając się zawrzeć polubowną ugodę z samym Bonerem. W celu ułożenia tej ugody wysłano do wielkorządcy krakowskiego 8-osobową komisję. Wchodzili do niej najwybitniejsi kapłani diecezji: trzech prałatów kapituły - dziekan St. Borek, archidiakon B. Gądkowski, scholastyk A. Czarnkowski, trzech najwyższych urzędników diecezjalnych - wikariusz generalny P. Myszkowski, oficjał generalny P. Porębski i kanclerz kurii A. Przecławski, a wraz z nimi poszli: referendarz J. Uchański i referent sprawy St. Hozjusz ${ }^{448}$. Ugoda się nie udała i zdaje się, że Hozjusz wycofał się od dalszych działań w sprawie bonerowskiej, uważając te zachody za beznadziejne ${ }^{449}$. Zresztą niedługo potem causa Boneroviana została przeniesiona na teren Rzymu, bo Seweryn Boner wniósł apelację do Stolicy Apostolskiej ${ }^{450}$. Sprawa wykonania rozliczenia kwestii majątkowych po śmierci Gamrata, która naraziła krakowską kapitułę na tak wielkie kłopoty, najlepiej wyraża jej stosunek do biskupa i wskazuje na to, że go lubiała i miała dla niego dużo wdzięczności i uznania. To zapewne skłoniło ją do przyjęcia obowiązku zajęcia się spadkiem, choć tego przykrego zadania bynajmniej nie musiała podejmować.

Hozjusz rzadko był wybierany przez kapitułę krakowską komisarzem do załatwienia spraw majątkowych. Zapewne szanowano jego czas, który poświęcał prowadzeniu przy boku S. Maciejowskiego agend państwowych, a wolne chwile wśród zajęć obracał na pracę naukową. Raz tylko w ciągu całego pobytu w kapitule krakowskiej wystąpił jako komisarz; w towarzystwie M. Kromera i Maura Rojzjusza wprowadzał Piotra Myszkowskiego w posiadanie majątku kapitulnego we Węgrzcach ${ }^{451}$, i raz tylko został wysłany przez kapitułę jako rewizor do przeglądu majątku kapitulnego w Łososkowicach, w ziemi proszowickiej. Inspekcja

${ }_{445}$ Tamże, k. 177'.

446 Tamże, k. 178.

447 Tamże, k. 178 -179 (1 X 1546).

448 Tamże, k. 180.

449 Tamże, k. $188^{\prime}-189$.

450 Tamże, k. 221'-231'. Sprawa ta ciągnęła się przez wiele lat i zamąciła czas żałoby po śmierci Zygmunta Starego (Cap. Crac. 4, k. 251, 251', 280, 282-283, 302'303'). Przedstawicielem rzymskim kapituły (scllicitator) był Jan Dębiński, kanonik poznański (Cap. Crac. 4, k. $319,322,331,374^{\prime}, 379$ ). Przedłużająca się sprawa Bonera dużo kosztowała kapitułę, bo musiała przesyłać prokuratorowi opłaty, np. $24 \mathrm{X}$ 1550 (tamże, k. 381), gdyż causa Boneroviana indecisa toczyła się w Rzymie jeszcze w r. 1557 (Cap. Crac. 5, k. 263, 276) i w r. 1558 (tamże, k. 315, 320).

451 Cap. Crac. 4, k. 164. 
ta odbyta $28 \mathrm{~V} 1546$ r. ${ }^{452}$ pozwoliła Hozjuszowi pozhać prestymonium, które za niecały rok sam miał wziąć w zarządzanie ${ }^{453}$.

W jesieni 1546 r. spotkał Hozjusza ze strony kapituły wielki zaszczyt i wyróżnienie. W związku bowiem z niedawno rozpoczętym soborem powszechnym krakowska kapituła domagała się wysłania przedstawiciela Kościoła polskiego do Trydentu. Ze swej strony wysunęła w dniu 22 X 1546 r. Stanisława Hozjusza, jako kandydata na tenże sobór, jakby przeczuwając, że jemu właśnie przypadnie wnieść wielki wkład w dzieło trýdenckiej odnowy Kościoła. Oczywiście do wyjazdu Hozjusza na sobór w tym czasie nie doszło ${ }^{454}$, ale uchwała ta jest bardzo charakterystyczna, bo ujawnia, jakie kapituła krakowska miała uznanie dla jego roztropności i wiedzy teologicznej.

Najwięcej czynny na terenie kapituły krakowskiej był Hozjusz w r. 1546, a jego obecność na zebraniach kapitulnych została zapisana w tym roku $\mathrm{w}$ aktach posiedzeń aż $45 \mathrm{razy}^{455}$. Jeszcze na początku r. 1547 Hozjusz pilnie uczęszczał na zebrania ${ }^{456} \mathrm{i}$ w tym czasie (dnia 15 II $1547 \mathrm{r}$.) był wybrany przez kapitułę deputatem w poselstwie do króla. Złożyło ono zażalenie na Andrzeja Zebrzydowskiego, lekceważącego nakazł̇ kapituły. Ta zaś polecała mu usunąć baraki kuchenne postawione przezeń na placu przylegającym do kościoła św. Marii Magdaleny, obok swej kamienicy (ul. Kanonicza 12). Kapituła bowiem już dawniej postanowiła, aby w tym miejscu urządzić studnię dla wspólnego użytku ${ }^{457}$. W połowie czerwca $1547 \mathrm{r}$. pojawiła się w Krakowie morowa zaraza ${ }^{458}$. Kapituła z obawy przed infekcją rozpierzchła się, tak samo Hozjusz z dworem królewskim usunął się z miasta i już do końca roku nie pojawił się w Krakowie. Mimo tej nieobecnęści Hozjusz został dnia 21 VII 1547 r. wybrany przez kapitułę jej delegatem na synod prowincjonalny zwołany do Eęczycy na dzień 15 IX tẻgo roku ${ }^{459}$. Przewodniczył temu synodowi

452 Tamże, k. 159 ;

453 Tamże, k. 200', 219.

454 Tamże, k. 189'.

455 W r. 1546 Hozjusz był obecny na zebraniu kapituły w następujących dniach: 8 I (Cap. Crac. 4, k. 126-128); 22 I $\left(130^{\prime}\right)$, 8 II (134); 12 II (136); 19 II (136); 26 II

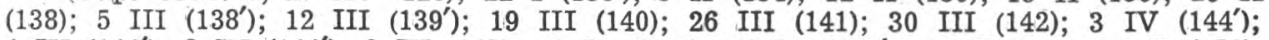

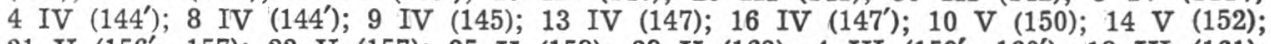
$21 \mathrm{~V}\left(156^{\prime}-157\right) ; 22 \mathrm{~V}(157) ; 25 \mathrm{~V}(158) ; 28 \mathrm{~V}(162) ; 4 \mathrm{VI}\left(159^{\prime}-160^{\prime}\right) ; 18$ VI (161); 26 VI (162); 1 VII (164); 9 VII (164'); 30 VII (167); 20 VIII (169'); 24 IX (177); 24 IX

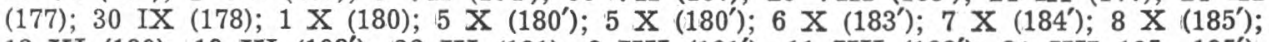
12 XI (190); 19 XI (198'); 26 XI (191); 3 XII (191'); 11 XII (192'); 31 XII 195-195'), ${ }_{456}$ W r. 1547 Hozjusz był obecny na posiedzeniach kapituły krakowskiej w następujących dniach: 7 I (Cap. Crac. 4, k. 196'); 18 I (200'); 20 I (202'); 3 II (204); 4 II $\left(204^{\prime}\right) ; 5$ II $\left(205^{\prime}\right) ; 9$ II $\left(207^{\prime}\right) ; 15$ II (210) idzie w deputacji do króla; 25 II (211); 2 III (211'); 18 III (214); 24 III $\left(215^{\prime}\right) ; 1$ IV (217); 15 IV (220'); 9 V (222'); 11 V $\left(222^{\prime}\right) ; 23 \mathrm{~V}\left(224^{\prime}\right) ; 27 \mathrm{~V}\left(221^{\prime}\right) ; 3$ VI $\left(228^{\prime}\right)$.

${ }_{457}$ Cap. Crac. 4, k. 210-210'. Jak wyżej wspomniano. Hozjusz był 22 IV 1547

r. wybrany do głoszenia egzort na tematy religijne (Cap. Crac. 4, k. 221).

458 Tamże, k. 231.

459 'Tamże, k. 235-235'.

36 - Analecta Cracoviensia 
— jak już wspominiano - w zastępstwie prymasa Mikołaja Dzierzgowskiego biskup krakowski i kanclerz Państwa Samuel Maciejowski. Być może, że wybór Hozjusza nastąpił na prośbę biskupa, który potrzebował pomocy tego najlepszego w Krakowie teologa w ułożeñiu ustaw synodu silnie podkreślających konieczność podniesienia poziomu oświaty i moralności duchowieństwa polskiego. Funkcję delegata kapituły krakowskiej na synod prowincjonalny kanonik Hozjusz piastował tylko jeden raz, tak samo tylko jeden raz kapituła posłała go jako swego przedstawiciela na sejm generalny, który u schyłku życia starego króla odbył się w Piotrkowie 5 I 1548 r. ${ }^{460}$ Niezależnie jednak od tego wyboru Hozjusz jako wielki sekretarz koronny stał zawsze blisko spraw państwowych.

Po ogłoszeniu ustania zarazy Hozjusz zjawił się w Krakowie dopiero 9 III 1548 r. ${ }^{461}$ Otrzymal on w tym czasie nową kurię kapitulną, opróżnioną przez śmierć lekarza królewskiego Jana Andreae de Valentinis przy ul. Kanoniczej 18. Dużo czasu pochłaniał mu remont tej kamienicy silnie zniszczonej i przez arcybogatego medyka mocno zaniedbanej ${ }^{462}$. Regulując granice parceli kapitulnej, miał nieporozumienia z sąsiadami Pileckimi, mieszkającymi z tyłu od ul. Grodzkiej ${ }^{463}$. Doszła mu jeszcze opieka nad domem przyjaciela i sąsiada Marcina Kromera, zamieszkałego przy ul. Kanoniczej 16, który w połowie czerwca $1548 \mathrm{r}$. wybrał się do Rzymu ${ }^{464}$. Podróż Kromera wypadła po śmierci króla Zygmunta Starego (1 IV 1548 r.). Hozjusz wziął udział w pogrzebie królewskim, odbytym dopiero w dzień św. Anny, tj. 26 VII 1548 r. ${ }^{465}$ Następujący po tej uroczystości okres wakacyjny został zakłócony w życiu Hozjusza ostrym sporem, jaki wywołał J. Uchański z powodu odmawiania doktorowi prawa swobodnego wyboru miejsca na składowanie dziesięciny złożonej mu przez mieszkańców Bieżanowa koło Krakowa ${ }^{466}$. Od dnia 1 IX 1548 r. Hozjusz ani razu nie był w kapitule obecny ${ }^{467}$. Dopiero dnia 1 III 1549 r. pokazał się w kapitularzu katedry krakowskiej i zasiadł na pierwszym miejscu jako biskup nominat chełmiński. Zapowie-

460 Tamże, k. 241'.

461 Tamże, k. 248.

${ }_{462}$ Tamże, k. 259-259', 276'.

${ }_{463}$ Tamże, k. 260.

${ }_{464}$ Tamże, k. 261'.

${ }^{465} \mathrm{Na}$ pogrzebie króla Zygmunta Starego Samuel Maciejowski, biskup krakowski, wygłosił mowę żałobną, której tekst ułożył Stanisław Hozjusz (Hos. eplae nr 297 , s. 266-268). Nazajutrz, 27 VII 1548 Hozjusz był obecny na zebraniu kapituły krakowskiej (Cap. Crac. 4, k. 270).

${ }_{466}$ Od 27 VII do 31 VIII 1548 Cap. Crac. 4, k. 270 i 280'.

467 Hozjusz był obecny w r. 1548 na zebraniach kapituły krakowskiej w mastępujących dniach: 9 III (Cap. Crac. 4, k. 248); 16 III (k. 248); 23 III (249); 6 IV $\left(\left(249^{\prime}\right) ; 27\right.$ IV $\left(251^{\prime}\right) ; 9$ V $\left.252^{\prime}\right) ; 18$ V $(257) ; 15$ VI $\left(248^{\prime}\right) ; 27$ VI $\left(251^{\prime}\right) ; 9$ V $\left(252^{\prime}\right)$; $18 \mathrm{~V}$ (257); 15 VI (261'); 27 VI (270); 27 VII (270); 3 VIII (271); 9 VIII (272'); 11 VIII $\left(274-274^{\prime}\right) ; 17$ VIII $\left(276^{\prime}\right) ; 23$ VIII $\left(279^{\prime}\right) ; 31$ VIII $\left(280^{\prime}\right)$. 
dział wówczas swój wyjazd do króla Ferdynanda w Pradze i do cesarza Karola V w Niderlandach. Przewidywał, że wróci w październiku i wówczas pożegna się z kapitułą krakowską ${ }^{468}$.

\section{STANISŁAW HOZJUSZ, KANONIK KRAKOWSKI, JAKO ADMINISTRATOR POSIADANYCH BENEFICJOW}

Dość wcześnie, jeszcze jako kleryk posiadający niższe święcenia, Stanisław Hozjusz czerpał swe utrzymanie z uposażeń kościelnych. Dawały mu one pomoc w czasie studiów zagranicznych, a gdy wrócił z nich do kraju - z laurem doktora obojga praw - w dalszym ciągu stanowiły główne źródło jego utrzymania na dworze biskupa krakowskiego Piotra Tomickiego. Jako domownik tegoż biskupa nosił tytuł prepozyta wielıńskiego i kanonika wiślickiego ${ }^{469}$. Po śmierci Tomickiego (zm. 1535 r.) zyskał jeszcze godność scholastyka skalbmierskiego ${ }^{470}(1437$ r.) i z tym tytułem objął na dworze królewskim obowiązek sekretarza (1538 r.). Równocześnie związał się z Kościołem warmińskim, gdzie w r. 1538 otrzymał kanonię, a rok później (1539) kantorię ${ }^{471}$. Niedługo potem, po śmierci kanonika krakowskiego Tomasza Rożnowskiego (1540), został instytuowany na kanonię kielecką fundi Brzechow ${ }^{472}$ i obdarowany prebendą św. Marii Egipcjanki w katedrze krakowskiej.

Mimo posiadania siedmiu wyżej wymienionych beneficjów, Hozjusz pragnął być jeszcze członkiem sławnej kapituły krakowskiej. To jego życzenie silnie popierał dwór królewski, biskup krakowski Piotr Gamrat i serdeczny jego przyjaciel Samuel Maciejowski, który w tym czasie posunął się na godność biskupią w Chełmie (1539). Jednakże w kapitule krakowskiej nie było wolnej kanonii; Maciejowski pospieszył mu z po-

468 Cap. Crac. 4, k. 301'-302. Hozjusz wyjechał jako poseł królewski w marcu 1549 r. najpierw do króla rzymskiego Ferdynanda przez Wrocław do Pragi, gdzie przebywał do lipca tego roku. Następnie przez Norymbergę udał się do Antwerpii, a potem od września aż do stycznia 1550 przebywał w Brukseli. W lutym znalazł się we Wiedniu i stąd przez Mistelbach (marzec 1550) wrócił do Polski. Dnia 23 VI 1550 r. złożył w Piotrkowie relację ze swego poselstwa (Hos. eplae I, nr 377 , s. $376-592)$.

${ }^{469}$ Ep. Crac. 13, k. 418, 448'-449, 451', 453, 460'; 15, k. 167'; 17, k. 4, 7, 14; Adm. Crac. 2, k. 69.

470 Ep. Crac. 18, k. 136'; 23, k. 7; Adm. Crac. 2, k. 6.

471 Hozjusz otrzymał kanonię warmińską dnia 15 VI 1538 r.; J. Sikorskli, Prebenda fromborska Stanistawa Hozjusza, "Biuletyn Informacyjny Postulatorskiego Ośrodka Studiów" 13 (1979) nr 10 s. 204. "Wziąwszy w r. 1439 kantorię warmińską Hozjusz ustąpił z tamtejszej kanonii. Dnia 20 I 1544 pisał z Piotrkowa do Dantyszka, że po czterech latach pragnie restytucji kanonikatu warmińskiego, ale znajduje wiele przeszkód w zrealizowaniu tego zamiaru (Hos. eplae I, s. 151-152; T. Pawluk, Kanonia warmińska Stanisława Hozjusza, „Prawo Kanoniczne“ 23, 1980, nr 3-4, s. 71-85). Według Pawluka przekazanie kanonikatu warmińskiego odbyło się 27 VII 1538 r.

${ }^{472}$ Ep. Crac. 22, k. 8. Brzechów znajduje się koło Daleszyc, w pobliżu Kielc. 
mocą w ten sposób, że zaproponował zaprzyjaźnionemu ze sobą Stanisławowi Słomowskiemu ${ }^{473}$ oddanie; mu lepszej niż dotychczas posiadał prebendy kanonickiej w Gnieźnie pod warunkiem, że zrezygnuje z kanonii krakowskiej na rzecz Stanisława Hozjusza. Słomowski się zgodził i zrzekł się prebendy szczytnickiej w katedrze krakowskiej, a dnia 25 II 1540 r. Stanisław Hozjusz został instytunowany na wakującą w ten sposób kanonię w obecności wicekanclerza Państwa Samuela Maciejowskiego i Karola Antoniego de Monte Cinere ${ }^{474}$ i następnie dnia 27 lutego 1540 r. Stanisław Hozjusz został instytuowany na wakującą w ten odstąpił Słomowskiemu kanonię kielecką prebendy brzechowskiej i prebendę św. Marii Egipcjanki na Zamku ${ }^{476}$. Słomowski zgłosił się do instytucji na prebendę zamkową 2 marca ${ }^{477}$, a na kanonię kielecką 10 marca 1540 r. $^{478}$

W związku z przyjęciem St. Hozjusza kapituła krakowska poczęła się użalać, że doktorzy plebejusze wchodzący do jej grona usiłują osiągnąć lepsze prebendy niż kanonicy szlachcice i uchwaliła, że odtąd wyznacza się dla plebejuszów tylko dwie prebendy kanonikalne, mianowicie szczytnicka, którą aktualnie miał zająć Hozjusz, i chmielnicką, którą posiada! Mikołaj Miłkowski. Posiadacz prebendy chmielnickiej gwałtownie zaprotestował przeciw tej uchwale, a nawet zapowiedział apelację do Rzy$\mathrm{mu}^{479}$. Nie wiadomo, jakie Miłkowski miał intencje, czy chodziło mu o to, że jego prebenda jest za bogata dla plebejuszów, czy oburzał się na dyskryminację tych kanoników; zdaje się, że chodziło mu o to drugie, bo dekret papieża Pawła III uchylił tę uchwałę kapitulną ${ }^{480}$.

Każdy z instalowanych prałatów lub kanoników, miał prawo otrzymać mieszkanie w domu kapitulnym. Hozjuszowi kapituła krakowska nie mogła szybko tego uczynić, bo mieszkania we wszystkich kamienicach kapitulnych były zajęte. Tę sprawę ułatwił Hozjuszowi znów inny przyjaciel $\mathrm{z}$ dworu biskupa P. Tomickiego Benedykt Izdbieński; wraz z S. Maciejowskim był on niegdyś osobistym sekretarzem wicekanclerza Państwa. Tenże Benedykt mieszkał przy ul. Kanoniczej, w domu położonym w tyle znajdującego się od strony ul. Grodzkiej Kolegium Kanonistów, lecz równocześnie posiadał solidum (czyli prawo do wspólnego mieszkania) w kamienicy przed niewielu laty odbudowanej przez sędzi-

${ }^{473}$ S. Słomowski wraz z S. Maciejowskim należeli do zaufanych prałatów kurii biskupa krakowskiego Piotra Tomickiego (Ep. Crac. k. 317).

474 Ep. Crac. 22, k. 15. Szczytniki kapitulne leżały koło Proszowic:

475 Cap. Crac. 3, k. 247'. Instalacja ta odbyła się ad effectum implendae constitutionis synodalis in synodo Piotrkoviensi laudatae (Hos. eplae I, nr 5, k. 44).

476 Ep. Crac. 18, k. 253.

477 Tamże, k. 255; Ep. Crac. 22, k. 17.

478 Ep. Crac. 18, k. 255; 22, k. 17.

479 Cap. Crac. 3, k. 245', 247, 248. Chmielnik, tzw. kielecki, koło Pińczowa.

480 Cap. Crac. 4 , k. $195^{\prime}-196$. 
wego scholastyka krakowskiego Mikołaja Bedleńskiego. Wykonanie tego solidum miało nastąpić po śmierci prałata. Izdbieński - będący ulubieńcem Bedleńskiego - skłonił stojącego nad grobem dygnitarza, by mu pozwolił jeszcze za swego życia wprowadzić się do jego domu (ul. Kanonicza 15), na co scholastyk (zresztą krótko przed śmiercią) wyraził zgodę $^{481}$. Wówczas Izdbieński, przenosząc się do domu Bedleńskiego, mógł odstąpić Hozjuszowi swój dom penes Collegium Iuristarum (ul. Kanonicza 8), dobrze utrzymany, dwa razy odnawiany, w którym nowo przyjęty kanonik znalazł schronienie na najbliższe trzy lata (1540$1543)^{482}$. Obsadę domów kapitulnych zatwierdzała kapituła. Na jej zebraniu w dniu 9 IV 1540 r. archidiakon Jerzy Myszkowski i Jan Naropiński, protestując przeciw przydziałowi kamienicy Hozjuszowi, odeszli z kapitularza, Stanisław Borek i Wilhelm Jarocki wstrzymali się od głosu (in perplexitate manentes), a gorąco poparli Hozjusza biskup Samuel Maciejowski, Stanisław Przeborowski, Andrzej Zebrzydowski, Maciej Drzewicki i Jan Drohojowski, którzy przeprowadzili uchwałę. Załatwiwszy w ten sposób sprawę prebendy i domu kanonikalnego mógł Hozjusz zupełnie poświęcić się służbie państwowej w kancelarii królewskiej, która się miała wkrótce przenieść z Wilna. W r. 1540 po wprowadzeniu się do domu przy ul. Kanoniczej tylko jeden raz zaglądnął do kapitularza, towarzysząc S. Maciejowskiemu, gdy ten jego bliski przyjaciel, a zarazem szef w kancelarii królewskiej, po niedawnym osiągnięciu godności biskupiej w Chełmie, zrezygnował dnia 25 IV 1540 r. z kanonii krakowskiej $^{483}$.

Zajęty w służbie państwowej Hozjusz zniknął w wykazach obecności na kartach kapitulnych ksiąg na przeciąg dwóch lat. Oddalońego od Krakowa spotykały jednak $\mathrm{w}$ dalszym ciągu fawory $\mathrm{w}$ dziedzinie uposażeń kościelnych, bo dnia 8 VI 1541 r. wystąpił Jan Barcik - skromny miłośnik ludzi uczonych, przyjaciel humanistów krakowskich - jako prokurator Hozjusza i objął w jego imieniu bogate probostwo w Gołębiu, z którego zrezygnował S. Maciejowski wtedy, gdy z biskupstwa chełmskiego został przeniesiony na stolicę płocką ${ }^{484}$. Gdy Hozjusz wrócił z Wil-

481 Już dnia 16 VIII 1538 r. Benedykt Izdbieński ustanowił prokuratorów do objęcia w jego imieniu domu kanonikalnego, który wówczas posiadał Mikołaj Bedleński (Cap. Crac. 3, k. 207). Kapituła przydzieliła ten dom Izdbieńskiemu (22 IV 1540 r. - Cap. Crac. 3, k. 253 i 269). Dnia 8 IV 1540 Benedykt Izdbieński zrezygnował z domu penes Collegium na rzecz Hozjusza (tamże, k. 349'-350), a dnia 9 IV tegoż roku M. Bedleński oddał swą kamienicę Izdbieńskiemu jako swemu solidatariuszowi (tamże, k. 250-251). M. Bedleński dał solidum B. Izdbieńskiemu już 30 VI 1536 r. po odbudowaniu domu (tamże, k. 148'-149), ale tylko po to, żeby mu zapewnić następstwo $w$ kamienicy po sobie. Benedykt dalej mieszkał penes Collegium aż do czasu, kiedy zaszła potrzeba opróżnienia tego domu, by zapewnić miejsce Hozjuszowi.

${ }_{482}$ Hozjusz otrzymał ten dom dnia 22 IV 1540 r. (Cap. Crac. 3, k. 253).

483 Tamże, k. 253-253'.

${ }^{484}$ Ep. Crac. 19, k. 47, 161. Hozjusz dwukrotnie wspomina w listach o swej 
na otrzymał 3 VII 1542 r., po śmierci kanonika Melchiora Sobka, prebendę rzemiądzką w katedrze krakowskiej. Prezentę na tę kanonię dał mu Jan Tarnowski, kasztelan krakowski. Nazajutrz Jan Barcik, prebendarz w Ruszczy, wyjechał z Krakowa, aby w imieniu Hozjusza objąć przyznane mu Rzemiędzice ${ }^{485}$.

Niedługo jednak Hozjusz posiadał tę kanonię. Obdarzony sporą ilością beneficjów kościelnych (w tym czasie dostała mu się również kanonia sandomierska ${ }^{486}$ ) i zaczynając aktywne życie w kapitule krakowskiej, postanowił zrzec się (w akcie rezygnacji z dnia 12 lipca 1542 r. ${ }^{487}$ ) tej drugiej prebendy krakowskiej (rzemiądzkiej); oddał ją bratu zmarłego -Melchiora, Zygmuntowi Sobkowi ${ }^{488}$, pozostając jedynie przy prebendzie szczytnickiej. Następnie zrezygnował z oddalonej prepozytury wieluńskiej, która stanowiła jego pierwotne uposażenie jeszcze w czasie pobytu na dworze biskupa krakowskiego Piotra Tomickiego ${ }^{489}$. Zygmunt Sobek, który wziął po Hozjuszu jedną z jego kanonii, zapragnął jeszcze jego

promocji na parafię w Gołębiu. Dnia 3 VI 1541 r. pisał z Wilna do Dantyszka: Mihi quoque accidit non modo non petenti, verum etiam non opinanti, ut $\mathrm{Co}-$ lumba augerer, qua cesserat Reverenda Dominatio Vestra reverendissimo domino meo nominato (Hos. eplae I, nr 86, s. 108). Hozjusz się opierał i nie chciał przyjąć tej bogatej parafii. Pisał o tym z Wilna 13 VIII: Agebatur magno conatu, ut hac ego Columba non potirer, quam certe nec ambivi umquam: sed eam sacra maiestas regia avolasse dicebat (tamże, nr 92, s. 194). Król uważał sprawę za definitywnie załatwioną. Jeszcze w zeszłym roku (4 XI 1540) Hozjusz gratulowal M. Kromerowi, który absolutnie nie chciał przyjąć w zarząd żadnej parafii (gratulor tibi quoque tam philosophicum animum). Hozjusz się zwierza Kromerowi, że sam ma w tej sprawie pewne wątpliwości (si mihi explicaveris, magnam ex animo meo dubitationem exemeris). Następnie Hozjusz podał swój pogląd w tej kwestii. Żeby rozumowanie Hozjusza zrozumieć, trzeba przypomnieć, że ówcześni prałaci i kanonicy, biorąc beneficium curatum, sami musieli szuḳać sobie zastępców, którzy by opliekę duszpasterską $\mathrm{w}$ ich parafiach spełniali. A różnie to wyglądało. Zastępcy bywali czasem kapłanami złego prowadzenia się, niedbali, opuszczający swe obowiązki, gorszący parafian, a niejednolkrotnie źle opłacani przez beneficjatów zostawiali parafię i przenosili się w inne strony, w kościele zaś milkła służba Boża. Dużo zależałı od staranności samego posiadacza beneficjum. Dlatego Hozjusz sądzi, że jeżeli biskup nadaje parafię kapłanowi dla jego pobożności i nauki, w nadziei że ten gwarantuje ludowi dostateczną opiekę duszpasterską, nie szczędząc kosztów i starań, i bierze parafię w celu godziwego utrzymania (non autem Epicurum agat aut Sardanapalum) - to uchylając się od wzięcia parafii, może zgrzeszyć przeciw miłości chrześcijańskiej przez dopuszczenie do zarządu parafii niegodnego beneficjata (Hos. eplae I, $\mathrm{nr} 71$, s. 93-94). Na to, pisząc $\mathrm{z}$ Kraksowa do Wilna, Marcin Kromer przyjacielowi żartobliwie odpowiedział, że jeżeli nie jest w stanie osobiście spełniać pieczy pasterskiej, lecz zleca ją zastępcy, który zawsze może ją zaniedbać, to woli zgrzeszyć przeciw miłości chrześcijańskiej, niż narażać się na uczestniczenie $\mathrm{w}$ grzechach cudzych (peccata aliena) - tamże, nr 76, 31 XII 1540, r. 98-99.

485 Hos. eplae I, app. 10, s. 417-418. Rzemiędzice leżą nad Nidzicą, koło Skalbmierza.

${ }^{486}$ Cap. Crac. 3, k. 377'. Dnia 13 VI 1542 Hozjusz pisał z Sandomierza do Dantyszka: Huc Sandomiriam cum venissem, beneficio sacrae maiestatis regiae, gratia vero singulari reverendissimi domini mei Samuelis Maciejowski praeter spem et exspectationem meam factus sum canonicus Sandomiriensis.

487 Ep. Crac. 19, k. 363,$465 ; 22$, k. 145.

488 Cap. Crac. 3, k. $378^{\prime}-379$.

489 Ep. Crac. 22, k. 188. 
domu kapitulnego, położonego obok Kolegium Jurystów. Gdy po śmierci Kaspra Podłęskiego kapituła uchwałą z dnia 7 V 1543 r. przydzieliła Hozjuszowi dom pozostały po zmarłym przy ul. Poselskiej $12{ }^{490}$, wówczas Sobek objął opuszczony przez niego dom przy ul. Kanoniczej $8^{491}$. Nowo objęty dom przy ul. Legackiej, stanowiący niegdyś wspaniały dwór renesansowy biskupa krakowskiego Jana Chojeńskiego (1537-1538), przez ostatniego posiadacza Podłęskiego został zupełnie zniszczony. Kapituła oddając Hozjuszowi ten dom, zażądała gruntownego remontu kamienicy. Hozjusz, dobry i zapobiegliwy administrator majątków kościelnych przydzielonych mu przez kapitułę, niezwłocznie przystąpił do odnowie-

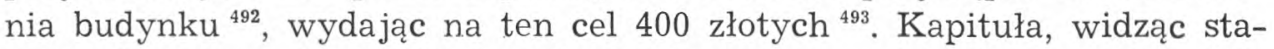
rania Hozjusza nie żałującego pieniędzy na przywrócenie dawnej świetności swej kamienicy, zwolniła go od płacenia taksy po rok $1545^{494}$.

W r. 1544 spotkało Hozjusza duże wyróżnienie ze strony biskupa krakowskiego i zarazem prymasa Piotra Gamrata, który mu odstąpił niektóre dziesięciny własnego biskupiego stołu (mensae episcopalis). Ten dar najczęściej spotykał nepotów biskupich. Swiadczy on o wielkim uznaniu i życzliwości dla Hozjusza ze strony biskupa. Po raz pierwszy Gamrat, kierowany specjalnym faworem, dał dnia 15 II 1544 r. swemu wybrańcowi dochody ze swego stołu w Ostrowcu i Posiłowie. Prokuratorem Hozjusza w tej sprawie był magister Jan Barcik ${ }^{495}$. Kapituła, której konsens na takie uszczuplanie uposażenia stołu biskupiego był wymagany, zatwierdziła zapis donatywy i dnia 16 V 1544 r. opatrzyła swymi pieczęciami ${ }^{496}$. Dalszym wyrazem uznania dla osoby, wiedzy i nauki Hozjusza ze strony Gamrata była powtórna donacja dziesięcin biskupich w Porębie, Lisiej Górze, Jaworsku i Zirczowie. Przed zatwierdzeniem tej darowizny przez kapitułę Gamrat odszedł z tego świata. Już po jego śmierci Hozjusz zwrócił się do kapituły o zatwierdzenie łaski udzielonej mu przez nieboszczyka biskupa. Przychylna mu kapituła $1 \mathrm{X}$ 1545 r. aprobowała akt Gamrata ${ }^{497}$, a dnia 17 X 1545 . poleciła zawiesić pieczęcie u spodu dokumentu powyższego dożywotniego nadania ${ }^{498}$.

490 Cap. Crac. 3 , k. 415 .

491 Tamże, k. 418', 419'.

492 Cap. Crac. k. 39: Domus sumptuose et optime constructa et restaurata. Od strony stojącej za domem Hozjusza kurii Jana Tarnowskiego, kasztelana krakowskiego, został odnowiony mur graniczny (tamże, k. 63).

${ }_{493}$ Tamże.

494 Cap. Crac. 4, k. $58,58^{\prime}$.

495 Tamże, k. 8'. Dziesięciny biskupie z Ostrowa i Posiłowa płacone były z parafii Kościelec za Proszowicami (Liber beneficiorum II, k. 1, 166).

496 Tamże, k. $17^{\prime}$.

497 Tamże ,k. 102'. Poręba Radlna i Lisia Góra leżą koło Tarnowa, Jaworsko koło Porąbki Uszewskiej, a Żerków koło Biesiadek.

498 Tamże, k. 115. 
Zasobny w dochody beneficjalne Hozjusz mógł się zdobyć na odruch współczucia wobec Andrzeja Góreckiego, dworzanina i sekretarza, któremu niejaki Mikluszewski zagarnął należne dochody; doktor odstąpił mu swoją dziesięcinę ${ }^{499}$. Sam Hozjusz nie zajmọwał się zbieraniem dziesięcin z pól swej prebendy w Szczytnikach i nie trzymał w tym celu osobnego faktora, lecz sprzedawał je „na pniu”. Już w kwietniu 1546 r. Hozjusz zawarł umowę $\mathrm{w}$ sprawie sprzedaży dziesięcin z Bartłomiejem, plebanem z Pleszowa ${ }^{500}$.

Za życia biskupa Gamrata Hozjusz zadowalał się posiadaniem tylko jednej prebendy, mianowicie szczytnickiej, należącej do jego kanonii, nie licząc objęcia na dziewięć tylko dni prebendy rzemiądzkiej. Gdy po śmierci Gamrata na stolicę biskupią w Krakowie wstąpił Samuel Maciejowski, Hozjusz począł przyjmować kapitulne beneficia prestymonialne, to jest majątki nie związane na stałe z żadną prałaturą czy kanonią, lecz dobierane przez członków kapituły drogą opcji według starszeństwa (secundum senium). Po raz pierwszy Hozjusz optował 8 I 1546 r. na Garlicę, położoną na północ od Krakowa, za Zielonkami ${ }^{501}$. Garlica wakowała po scholastyku A. Czarnkowskim, który pragnął przenieść się do Zielonek opuszczonych przez Piotra Myszkowskiego ${ }^{502}$. Jednak Czarnkowski nie był zadowolony z tej zmiany i postanowił powrócić do Garlicy. Zaproponował więc zamianę Hozjuszowi, a ten zgodził się bez trudu oddać Garlicę A. Czarnkowskiemu, zaś sam przeniósł się dnia 1 VII 1546 r. do Zielonek zwolnionych dla niego przez Czarnkowskiego ${ }^{503}$. Kapituła, dając Zielonki Hozjuszowi - jakby w obawie, że ten humanista nie da sobie rady z zarządzaniem majątkiem - prosiła go, by wyznaczył do prestymonium dobrego ekonoma i włodarza. Obawa była próżna, bo okazało się później, że Hozjusz należał do najlepszych gospodarzy majątków kapitulnych. Był oprócz tego pilny, oszczędny, prowadził życie skromne, nie wyrzucał pieniędzy na huczne biesiady, jak niektórzy z jego kolegów, którzy mimo bogatego uposażenia zostawiali po śmierci jedynie długi. W miesiąc po objęciu prestymonium w Zielonkach Hozjusz, kanonik prebendy szczytnickiej, wziął 31 VII 1546 drugą obok Gołębia bogatą plebanię w Radłowie koło Bochni, którą mu zostawił wierny w przyjaźni Benedykt Izdbieński, odchodzący na biskupstwo poznańskie $^{504}$.

Po śmierci Erazma Ciołka, sufragana krakowskiego (zmarł 6 XII

499 Ep. Crac. 25, k. 148, 162. Dnia 25 V 1548 r. Górecki otrzymał od Samuela Maciejowskiego wieś Żydówek w dożywocie (Cap. Crac. 4, 225).

500 Ep. Crac. 25, k. 19-20 (28 IV 1546).

501 Cap. Crac. 4, k. 128.

502 Tamże, k. 164.

503 Tamże, k. 183.

504 Ep. Crac. 25, k. 172-174; 27, k. 12. 
1546 r.), Hozjusz w dzień Starego Roku objął po nim w katedrze krakowskiej drugą prebendę, mianowicie bieżanowską. Kapituła posłużyła sıę motywacją, że skoro Paweł III zabronił przy obsadzie prebend kapitulnych dyskryminować kanoników plebejskich, to Hozjusz, mimo że na leżał do quinarius numerus plebeorum, mógł być pod tym względem zrównany ze szlachtą ${ }^{505}$. Zdaje się, że z powodu objęcia prebendy bieżanowskiej miał jakieś trudności, bo dnia 7 IV 1547 r. zrezygnował z tej kanonii na rzecz kolegi z kapituły warmińskiej Wojciecha Kijowskiego ${ }^{506} \mathrm{z}$ zastrzeżeniem sobie jednak pensji beneficjalnej, którą miały stanowić oddane mu do użytku dziesięciny z samego Bieżanowa i z Pieczonogów koło Wrocimowic z ziemi proszowskiej.

$\mathrm{Za}$ to jeszcze w styczniu (18 I 1547 r.) przeprowadził Hozjusz bardzo korzystną wymianę prestymoniów, oddając Zielonki (gdzie już zdążył przygotować materiał do remontu), a biorąc słynną z bogatych urodzajów wieś Łososkowice, którą A. Zebrzydowski, mimo że został biskupem, nie chciał przez wiele lat opuścić ${ }^{507}$. Z Hozjuszem pojechał do Łososkowic Marcin Kromer, by w imieniu kapituły krakowskiej przekazać prestymonium nowemu posiadaczowi. Spotkała ich przykra niespodzianka, bo Zebrzydowski ustępując z Łososkowic początkowo na rzecz Zbigniewa Ziółkowskiego (który jednak wolał wziąć Goszczę), przeniósł stogi zboża z pól łososkowskich na grunta sąsiedniej wsi Skrzeszowic, a potem to zboże sprzedał ${ }^{508}$. Hozjusz zajął się Łososkowicami bardzo gorliwie. Dla przeprowadzenia koniecznych remontów w tamtejszym dworze ${ }^{509}$ sprowadził drzewo z lasu w Goszczy, na co ze względu na wielkie zniszczenie Łososkowic kapituła bez trudności wyraziła zgodę ${ }^{510}$. Dobrał też odpowiedniego ekonoma, oczyścił (dziś wysychający) staw, odnowił (dziś nie istniejący) młyn i regulował granice beneficjum, odzyskując zaorane pola od strony Gnatowic ${ }^{511}$ i odbierając od Mikołaja Lutomirskiego, tenutariusza Skrzeszowic, należących wówczas do Tarnowskich, sporny mórg pola ${ }^{512}$.

Tymczasem w Krakowie po śmierci Jana de Valentinis z Modeny, lekarza królewskiego, zawakowała kamienica kapitulna leżąca blisko Wa-

505 Cap. Crac. 4, k. 195'-196.

506 Ep. Crac. 25, k. 567; Cap. Crac. 4, k. 220'.

507 Cap. Crac. 4, k. 200, 219. Zob. opis wsi prestymonialnych umieszczony pod r. $1544 \mathrm{w}$ Cap. Crac. 4 , k. $39-44$, m. in. i Eososkowic (k. $41-42)$.

508 Tamże, k. 209, 210.

509 Leżący na granicy wsi Łososkowice i Skrzeszowice dawny dwór kapitulny zachował się, lecz został gruntownie przebudowany i zredukowany. Pierwotnie składał się z wielkiej izby czeladnej od zachodu i 4-pokojowej części mieszkalnej od wschodu. Wejście od południa i północy prowadziło przez ganki. Obszar dawnych zabudowań dworskich należy w jednej części do rodziny Haberów, a w drugiej do Przybyszewskich.

510 Cap. Crac. 4, k. 220', 221'.

511 Tamże, k. 200.

512 Tamże, k. 219, 382. 
welu, naprzeciw kurii „,św. Stanisława” (ul. Kanonicza 18). Hozjusz optował na ten dom i otrzymał go dnia 24 III 1547 r. Opuścił wówczas dotychczasowe mieszkanie przy ul. Poselskiej, które zajął Jan Podlodowski, nepot biskupi ${ }^{513}$. Był to trzeci i ostatni dom, jaki Hozjusz posiadał z tytułu godności kanonika krakowskiego. Dnia 1 VI 1548 r. Hozjusz przedstawił na zebraniu kapitulnym stan ogromnego zniszczenia w swej kamienicy, dotychczas posiadanej przez lekarza Włocha. Wówczas kapituła postanowiła, że dochody tzw. roku łaski (anni gratiae) z beneficjów należących niegdyś do Jana de Valentinis, a szczególnie z prepozytury krakowskiej i prepozytury kolegiaty św. Floriana, nie będą wydane spadkobiercom, ale będą obrócone na cele remontu domu zaniedbanego przez nieboszczyka i dane do dyspozycji Stanisława Hozjusza ${ }^{514}$.

W ciągu roku 1548 mieszkający już w nowej kamienicy (ul. Kanonicza 18) Hozjusz miał dwie kłopotliwe sprawy: jedną z Pileckimi, którzy posiadali dom w tyle kurii Hozjusza od strony ul. Grodzkiej, porządkowanie bowiem gospodarstwa na granicy tych posiadłości naraziło go na zatarg z sąsiadami ${ }^{515}$, i drugą, dużo gorszą, z Jakubem Uchańskim. Konflikt z Uchańskim rozgorzał w miesiącach letnich tegoż roku od 27 lipca ${ }^{516}$. Dnia 9 VIII 1548 r. Uchański złożył przed kapitułą krakowską formalne zażalenie na Hozjusza, oskarżając go o złośliwe zaniedbanie zbierania dziesięcin w Bieżanowie w tym celu, by kmieci bieżanowskich narazić w związku z tym na większe koszta z powodu zniszczenia plonów i samemu na tym dobrze skorzystać ${ }^{517}$. Ta sprawa była omawiana przez kapitułę na posiedzeniu dnia 11 VIII i wykazała nie-

513 Tamże, k. 216'-217, 257, 257'.

514 Tamże, k. 259-259', 276.

515 Tamże, k. 260 (8 VI 1548).

516 Tamże, k. 270, 271. Bieżanów stanowił prebendę kanonikalną, której dziesięciny pobierał Hozjusz, a zarazem prestymonium kapitulne, należące do Jakuba Uchańskiego, przyznane mu 5 X 1546 r. (Cap. Crac. 4, k. 181').

517 J. Korytkowski (Arcybiskupi, t. III, s. 279) przytoczył w życiorysie J. Uchańskiego jego oszczercze oskarżenie, zwrócone dnia 9 VIII 1548 przeciw Hozjuszowi rzekomo $\mathrm{w}$ imieniu kmieci bieżanowskich, jakoby Hozjusz ociaggał się w odebraniu od nich należnej dziesięciny $w$ tym celu, żeby zboże na polu zgniło, a on za to wziął gotówką więcej, niżby ta dziesięcina była warta. Uchański prosił o ukaranie za to Hozjusza. Autor życiorysów arcybiskupów gnieźnieńskich nie zatroskał się o to, ażeby tę sprawę przebadać do końca. Przedstawiała się ona inaczej. Hozjusz od dawna chciał zebrać dziesięcinę i złożyć u zaufanego kmiecia Dębiela iz Bieżanowa. Regent (Uchański) jednak zagroził Dębielowi śmiercią (nece) lub wyrzuceniem go z gospodarstwa, jeżeliby się odważył przyjąć dziesięcinę Hozjuszową. $\mathrm{Za}$ to miejscowy rządca zmuszał kmieci, aby dziesięcinę składali u niejakiego Chrząszcza z Bieżanowa, czemu Hozjusz się sprzeciwiał, bo nie miał do tego człowiekla zaufania. Hozjusz dodał jeszcze przed kapitułą, że iile razy w dzień pogoodny chciał przystąpic do zbierania dziesięciny, rządca bieżanowski wypędzał kmieci do robót polnych. Kapituła krakowska stanęła po stronie Hozjusza i na skutek złośliwości Uchańskiego musiała wydać dekret de libera locatione decimae, to znaczy, że każdy członek kapituły może magazynować swą dziesięcinę tam, gdzie mu się podoba. Jednocześnie kapituła zagroziła Uchańskiemu pozbawieniem go prestymonium bieżanowskiego, jeżeli nie będzie się stosował do tego dekretu (Hos. eplae I, app. 22, s. 431-434; Cap. Crac. 4, k. 258). 
winność Hozjusza ${ }^{518}$. Ostatniego sierpnia 1548 r. tak Jakub Uchański, jak i Hozjusz wycofali się $\mathrm{z}$ apelacji, aby mogli odprawić swoje hebdomady ${ }^{519}$. Ta sprawa już więcej nie pojawiła się na kartach akt kapitulnych.

W tym czasie ogólnie spodziewano się, że Hozjusz w myśl życzenia króla Zygmunta I osiągnie wkrótce po śmierci dogorywającego Dantyszka biskupstwo na Warmii. Licząc się z tym faktem, Stanisław Słomowski, prepozyt kaliski, gnieźnieński i poznański kanonik, prosił kapitułę krakowską o prawo regresu (powrotu) na kanonię szczytnicką, z której - jak wiadomo - przed 8 laty zrezygnował na rzecz Hozjusza, biorąc za to sowite wynagrodzenie. Aby uczynić tę sprawę sporną i w ten sposób łatwiej uzyskać regres na dawniej posiadane beneficjum, zarzucił Hozjuszowi z wyrachowaną przebiegłością, że tę kanonię niesłusznie mu zabrał ${ }^{520}$.

Niedługo potem umarł Dantyszek (27 X 1548 r.), lecz na biskupstwo warmińskie przesunął się nie Hozjusz, lecz Tideman Giese, biskup chełmiński, i dopiero na jego miejsce do Chełmna został wyznaczony przez króla Zygmunta Augusta Stanisław Hozjusz. Fakt nominacji Hozjusza na biskupa chełmińskiego był zapowiedzią jego odejścia $\mathrm{z}$ kapituły. Choć zatwierdzenie rzymskie miało przyjść dopiero za pół roku, elekt począł powoli rezygnować z beneficjów. Najpierw w dniu 23 II 1549 r. zrzekł się kanonii wiślickiej fundi Zdrochecka ${ }^{521}$. Nieco później, dnia 1 III 1549 r., Hozjusz przyszedł osobiście do kapitularza krakowskiego i przedstawił kapitule, że osiągnąwszy biskupstwo chełmińskie jest obowiązany zrzec się beneficjów posiadanych z tytułu kanonii krakowskiej. Ponieważ w krótkim czasie miał wyjechać w legacji do cesarza Karola V, prosił kapitułę, by pozwoliła mu - mimo rezygnacji z kanonikatu krakowskiego - zatrzymać wieś prestymonialną Łososkowice i kamienicę kapitulną przy ul. Kanoniczej aż do powrotu przypuszczalnie w październiku. Prośbę swą uzasadniał tym, że bardzo dużo wydał pieniędzy na podniesienie gospodarcze Łososkowic, zaniedbanych przez A. Zebrzydowskiego, i na remont domu przy ul. Kanoniczej po śmierci włoskiego lekarza Valentino. Kapituła wyraziła na to zgodę ${ }^{522}$.

Niedługo przed wyjazdem Hozjusza w dniu 8 III 1549 r. zrzekł się osobiście dziesięcin prebendy bieżanowskiej na rzecz Wojciecha Kijowskiego ${ }^{523}$. Po wyjeździe Hozjusza jego pełnomocnik kustosz wiślicki Mar-

518 Cap. Crac. 4, k. 274-274'.

519 Tamże, k. $280^{\prime}$.

520 Tamże, k. $276^{\prime}$.

521 Ep. Crac. 26, k. 146. Dnia 3 II 1549 Zygmunt August donosił Tydemanowi Giese, że na stolicę chełmińską mianował Hozjusza, kantora i kanonika warmińskiego (Hos. eplae I, app .34, s. 435-436).

522 Cap. Crac. 4, k. 301'-302.

${ }_{523}$ Zob. przypis 500 . 
cin Kromer zrezygnował w jego imieniu dnia 2 X 1549 r. z kanonii krakowskiej prebendy szczytnickiej, na którą został instytuowany od dawna na nią czekający kanonik gnieźnieński Stanisław Słomowski ${ }^{524}$. Marcin Kromer, jako zastępca i prokurator Hozjusza, przedstawił w kurii biskupiej dnia 6 X 1549 r. zrzeczenie się scholasterii skalbmierskiej, którą po Hozjuszu wziął Łukasz Aquilinus, kaznodzieja katedralny. Biorąc scholasterię Aquilinus zrzekł się zarządu parafii w Bieżanowie ${ }^{525}$. Dwa dni później $(10 \mathrm{X})$ tenże sam prokurator M. Kromer w imieniu Hozjusza zrzekł się parafii w Radłowie ${ }^{526}$, którą na prezentę szwagra biskupiego Jana Leżeńskiego, kasztelana małogosteckiego, wziął Piotr Myszkowski ${ }^{527}$. Zebrana nazajutrz kapituła krakowska wyraziła wielkie pochwały pod adresem Hozjusza za wzorowe utrzymanie prestymonialnej wsi Łososkowice i przydzieliła ją - z chwilą rezygnacji z niej biskupa chełmińskiego - archidiakonowi Bartłomiejowi Gądkowskiemu. Obecny na tym zebraniu Marcin Kromer odczytał dyspozycje Hozjusza dotyczące wsi Łososkowice ${ }^{528}$. Dopiero przy końcu roku, dnia 12 XII 1549, zgłosił przedstawiciel Hozjusza rezygnację z kanonii sandomierskiej, na którą został instytuowany siostrzeniec biskupa S. Maciejowskiego, kleryk niższych święceń Marian Leżeński ${ }^{529}$.

Związek St. Hozjusza z kapitułą krakowską trwał aż do 10 IV 1550 to jest do dnia, w którym biskup chełmiński przez swego domownika Kuczborskiego zrezygnował $\mathrm{z}$ posiadanych dotychczas Łososkowic i kamienicy kapitulnej przy ul. Kanoniczej 18. Kapituła krakowska,-przyjmując zrzeczenie się Hozjusza odnośnie do ostatnich beneficjów, zażądała od jego prokuratora zapłaty taksy rocznej należnej od kamienicy kapitulnej w wysokości 40 grzywien. Pełnomocnik Hozjusza oświadczył, że jego mocodawca, bawiąc w podróży na dwór cesarski, wyczerpał wszystkie zasoby, gdyż koszta legacji opłacał z własnej kieszeni, dlatego prosił o zniżkę opłaty, tym bardziej że w kamienicy, którą opuszcza, wykonał znaczne remonty ${ }^{530}$. Kapituła przychyliła się do tej prośby, zlecając Hozjuszowi zapłacić tylko dług kapitulny w wysokości 26 grzywien.

W r. 1550 Hozjusz opuścił swe rodzinne miasto Kraków, mając skończonych 45 lat życia. To miasto, jego uniwersytet, dwór biskupi i kró-

${ }^{524}$ Ep. Crac. 26, k. 308; Cap. Crac. 4, k. 350'.

525 Ep. Crac. 26, k. 314.

526-Tamże, k. 317.

527 Tamże, k. 326.

${ }^{528}$ Cap. Crac. 4, k. 236-236'. Dla obserwującego dobrą administrację majątków kapitulnych w Krakowie, gdzie Hozjusz wykazywał dużo zmysłu ekonomicznego, odnawiał wspaniale domy kapitulne, w których mieszkał, podnosił stan gospdarczy majątków kapitulnych, żył oszczędnie i nie brakowało mu pieniędzy na te cele, prawdziwą niespodzianką jest fakt, że kapituła warmińska atakowała go jako swego biskupa za złą gospodarkę w diecezji (W. Odyniec, Wstęp do wydania Poezji Stanisława Hozjusza, s. XLVIII, LII, LV).

529 Ep. Crac. 26, k. 365.

530 Cap. Crac. 4 , k. $358^{\prime}-359$. 
lewski, związek z tutejszym światem intelektualnym i krakowską kapitułą dały mu formację duchową, podstawy jego teologii i działalności kościelnej, czym tak bardzo przysłużył się katolickiej wierze i Soborowi Trydenckiemu.

\section{OBRAZ KAPITUEY KRAKOWSKIEJ ZA CZASOW HOZJUSZA}

Kapituła krakowska, jak zresztą każda inna kapituła katedralna, była uważana za senat biskupi i miała obowiązek pomagać biskupowi w rządach diecezją. Dostarczała ona swemu biskupowi przede wszystkim wysokich urzędników diecezjalnych. Do nich należał kanclerz kurii, stojący na czele przybocznej kancelarii biskupiej. Tenże kanclerz nieraz w zastępstwie biskupa przewodniczył rozprawom kurialnym, ale do ogłoszenia wyroku sądowego musiał mieć nominację na audytora kurii. Jeżeli jej nie posiadał, zlecał napisanie i odczytanie wyroku sędziemu--audytorowi, danemu mu przez biskupa, a tym sędzią-audytorem bywał doświadczony prawnik. Obok kurii biskupiej w Krakowie istniały jeszcze dwa konsystorze; na czele jednego stał wikariuš generalny biskupi w sprawach duchownych, a drugiemu przewodniczył oficjał generalny. Wikariusz na mocy delegacji biskupa mógł spełniać wszystkie funkcje pasterskie biskupa z wyjątkiem zastrzeżonych, np. instytucji kanoników katedralnych. Wikariusz generalny miał władzę sędziowską, lecz najszerzej jurysdykcję sądowniczą w diecezji wykonywał oficjał generalny, który jako sędzia był alter ego biskupa; dlatego od jego wyroku nie można było apelować do ordynariusza, lecz do wyższej władzy, np. do arcybiskupa gnieźnieńskiego, z tym że przeważała jednak praktyka odnoszenia się Stolicy Świętej. Apelacja winna była być dokonana za wiedzą sądu pierwszej instancji, który odwołującemu się dawał tzw. apostoli, lub list odsyłający.

St. Hozjusz jako kanonik krakowski stykał się z powyższymi wysokimi urzędnikami diecezjalnymi za rządów dwóch biskupów: Piotra Gamrata (1538-1545) i Samuela Maciejowskiego (1546-1550). Pierwszy z nich obrał sobie za kanclerza kantora krakowskiego Jana Wilamowskiego (1 XI 1538-22 XII 1539); mianowany biskupem kamienieckim, opúścił kancelarię i wkrótce zmarł (6 XI 1540). Jego następcą został Bartłomiej Gądkowski, kanonik krakowski i kanclerz poznański (22 XII 1539-27 VIII 1545), który na swym stanowisku trwał do końca życia Gamrata. Za pomocnika w charakterze audytora do wygłaszania wyroków sądowych Gamrat dał pierwszemu i drugiemu kanclerzowi doktora dekretów Zygmunta ze Stężycy, profesora prawa kanonicznego. Wszyscy trzej należeli do przykładnych kapłanów i odznaczali się roztropnością 
w wykonywaniu jurysdykcji sądowniczej. Następca Gamrata Samuel Maciejowski wziął za kanclerza kurii Jana Przerębskiego, należącego do najzacniejszych ludzi w kapitule krakowskiej, późniejszego (1559-1562) prymasa Polski. Przerębski nie był długo kanclerzem (4 IV_-25 X 1546), bo S. Maciejowski, biskup, a zarazem kanclerz Państwa, chciał go mieć zawsze przy sobie jako najbliższego doradcę. Odwołał go przeto z tego stanowiska i na jego miejsce wyznaczył Andrzeja Przecławskiego (2 VIII 1546 -25 X 1550).

Wikariuszem generalnym w sprawach należących do jurysdykcji duchownej (in spiritualibus) był za Piotra Gamrata sędziwy Mikołaj Bedleński. Pełnił ten urząd za czterech poprzednich biskupów, a do kapituły wszedł jeszcze za Fryderyka Jagiellończyka, zmarłego - jak wiadomo - w r. 1503. Dobrze zasłużony dla diecezji krakowskiej odszedł z tego świata 17 IV 1540 r. Po jego śmierci urząd wikariusza wykonywał zastępczo oficjał generalny Paweł Krassowski (17 IV 1540-5 V 1541), aż do ogłoszenia przez biskupa P. Gamrata nowego wikariusza generalnego, którym został kanonik krakowski Benedykt Izdbieński (8 V 1541 - 27 VIII 1545). Izdbieński był człowiekiem o dużym znaczeniu na dworze królewskim, w kapitule i diecezji. Był urzędnikiem zdolnym i wytrwałym pracownikiem, szczególnie dobrym prawnikiem, ale człowiekiem rozrzutnym, ciągle potrzebującym pieniędzy. Ta wada rzuciła plamę na jego późniejsze w latach 1546-1553 rządy biskupie w Poznaniu. Wikariuszem generalnym S. Maciejowskiego był młody, wykształcony w Padwie przyjaciel Klemensa Janickiego i Jana Kochanowskiego Piotr Myszkowski (7 IV 1546—25 X 1550), późniejszy (15771591) biskup krakowski.

W konsystorzu oficjała generalnego prowadził sądy za Gamrata stary kierownik tej instytucji, zowiący się „quinque episcoporum Cracoviensium officialis" Tomasz Rożnowski (zmarł 21 I 1540). Na jego miejsce przyszedł Paweł Krassowski i wykonywał urząd oficjała do końca życia bpa Gamrata. Krassowski był dobrym kapłanem i sumiennym pracownikiem. Po śmierci Gamrata kierownictwo konsystorza oficjalskiego objął na zlecenie S. Maciejowskiego jego dawny kolega z dworu biskupa P. Tomickiego Piotr Porębski. Urzędnicy biskupa Maciejowskiego, tak wikariusz P. Myszkowski, jak i oficjał P. Porębski, obaj pochodzący z terenu oświęcimskiego, doskonale się nawzajem uzupełniali. Wysuwano w tym czasie zarzut (zaznaczył się on w słynnej instrukcji kapituły krakowskiej z r. 1551), że w przeciwieństwie do biskupa Jana Konarskiego (1503-1524) i Piotra Tomickiego (1524-1535), dokonujących wyboru na swych urzędników spośród diecezjalnych prałatów ze stopniami naukowymi - późniejsi biskupi Piotr Gamrat i Samuel Maciejowski mianowali na stanowiska kurialne kapłanów wprawdzie 
członków kapituły, ale bez żadnego stopnia. Jednakże trzeba przyznać, że wyborów tych dokonywano starannie i urzędnicy 'tych ostatnich biskupów byli dobrymi praktykami, doskonale znali sprawy i potrzeby swego urzędu, odznaczali się dobrymi obyczajami, pracowitością i oddaniem swemu biskupowi. Jedynie Izdbieńskiemu, który nie miał żadnych zarzutów natury obyczajowej, można było wytknąc brak solidności w sprawach materialnych.

Prócz urzędników diecezjalnych kapituła katedralna dostarczała biskupowi tzw. prałatów kurii, przebywających w jego towarzystwie w komnatach domu biskupiego. Wyjeżdżali oni wraz $\mathrm{z}$ nim $\mathrm{w}$ podróż na zjazdy kościelne czy państwowe, na inspekcję zamków i dworów w kluczach majątkowych, służyli mu radą $\mathrm{w}$ dziedzinie teologii i prawa kościelnego, udzielali wskazówek w sprawach zarządu gospodarczego dóbr stołu biskupiego, posiadali umiejętność dyskusji na tematy sztuki, literatury i odznaczali się zaletami towarzyskimi. Do nich za biskupa P. Gamrata należli: Stanisław Borek, gnieźnieński i krakowski kantor, prałat wielkiej powagi i zacności, Erazm Ciołek, opat mogilski, którego tenże biskup wybrał na sufragana krakowskiego (1544-1545), Stanisław Hozjusz, doktor obojga praw, kantor warmiński, Marcin Kromer doktor obojga praw, kustosz wiślicki, pełniący funkcję osobistego sekretarza biskupa, Albert Kijowski, włocławski i warmiński kanonik, Zygmunt ze Stężycy, doktor dekretów, profesor prawa na Uniwersytecie Krakowskim, Jakub z Biskupic, doktor medycyny, nadworny lekarz, Jan Drohojowski, kanonik krakowski, później biskup kamieniecki, chełmski i kujawski (1545-1557), Karol Antoni de Monte Cinere, prepozyt pułtuski, Maciej Drzewicki (młodszy), kanonik krakowski, Maciej Bal kanonik krakowski, krewniak biskupa; a także kanonicy: Stanisław Konar.ski, Jerzy Podlodowski, Filip Padniewski, Piotr Myszkowski. Archidiakon krakowski Jerzy Myszkowski, doktor obojga praw, tylko z początku rządów Gamrata bywał na jego dworze biskupim. Potem się do niego zraził, bo zauważył, że dalsza kariera duchowna jest dla niego nieosiągalna i rozgoryczony wystąpił nawet przeciw biskupowi na ambonie.

Kilku prałatów kurialnych przeszło z dworu P. Gamrata do otoczenia jego następcy, biskupa Samuela Maciejowskiego. Przede wszystkim byli to obaj doktorzy prawa i humaniści: Stanisław Hozjusz i Marcin Kromer, ponadto Wojciech Kijowski, Jerzy Podlodowski, kanclerz królowej Elżbiety z bratem Janem występujący w roli nepota biskupiego, przyszły biskup krakowski Piotr Myszkowski (1577-1591), a nie przyłączył się Filip Padniewski, mający kiedyś (1572-1577) również zasiąść na stolicy krakowskiej. Oprócz nich pojawiły się przy boku S. Maciejowskiego nowe postacie $\mathrm{z}$ kapituły krakowskiej. Pierwszym prałatem kurii był jego ulubiony kapłan Jan Przerębski, prepozyt chrząstowski, 
późniejszy podkanclerzy Państwa i prymas. Następne postacie to: Andrzej Spot, późniejszy sufragan krakowski (1547-1559), następca Spota na sufraganii krakowskiej (1560-1565) Stanisław Słomowski, zmarły jako arcybiskup lwowski (1575), Walenty Herburt z Fulsztyna, później biskup przemyski (1560-1572), Paweł Tarło, przyszły arcybiskup lwowski (1561-1565), Bartłomiej Gądkowski, dawny kanclerz biskupa Gamrata. Odwiedzał dwór S. Maciejowskiego kolega ze, studiów, scholastyk krakowski Andrzej Czarnkowski, poza tym nieszczęsny Stanisław Przeborowski, dawny znajomy biskupa $\mathrm{z}$ dworu podkanclerzego Piotra Tomickiego.

Hozjusz spotykając się w kapitularzu ze współbraćmi z krakow:skiej kapituły, widział wśród nich kapłanów wzorowych, głęboko wierzących, przywiązanych do Kościoła, szanujących swego biskupa. Między innymi należy szczególnie wymienić takich członków kapituły, jak: Stanisława Borka, należącego do pierwszej generacji humanistów krakowskich jeszcze z czasów biskupa Piotra Tomickiego. profesorów: Stanisława Biela, Marcina Bełzę, Zygmunta ze Stężycy, Marcina Kromera, Wojciecha Kijowskiego, Walentego Herburta z Fulsztyna i wszystkich urzędników tak kurii, jak i obu konsystorzy generalnych. Nawet tacy wybitni humaniści, jak Filip Padniewski i Piotr Myszkowski byli wierni Kościołowi; gdy zostali biskupami krakowskimi byli wprawdzie upomniani przez kapitułę za opieszałość w zwalczaniu reformatorów, jednak warto dokładniej zbadać, czy ta postawa tolerancyjna nie była w tym czasie bardziej roztropna, niż surowa gorliwość.

Formację teologiczną i humanistyczną zdobywali członkowie kapituły krakowskiej za granicą: w Bolonii, Padwie, Rzymie, lub na uniwersytetach niemieckich. Niektórzy z nich w miejscu studiów wraz z wykształceniem chłonęli tamtejsze zepsucie obyczajów, formalne przywiązanie do wiary bez spełniania jej postulatów, nie krępowali się tradycyjną moralnością, a z pogardą odnosili się do scholastyki. Objawiali za to chęć błyszczenia i rozrzutnego przepychu. Do takich należeli: Stanisław Przeborowski, Jan Konarski prepozyt kolegiaty św. Michała na Wawelu, a zwłaszcza Wilhelm Jarocki. Gorszącym życiem grzeszył także Andrzej Zebrzydowski, który spędził młodość w rozwiązłości obyczajów, a później jako biskup tolerował w swej kamienicy (ul. Kanonicza 12) osoby uprawiające podejrzane schadzki. Późniejsza inkwizycyjna gorliwość biskupa Zebrzydowskiego miała swe źródło raczej w obawie przed obaleniem przez innowierców ówczesnego ustroju Państwa i utraty przodującej roli episkopatu w Polsce, niż w gorliwości religijnej.

Nie brakło też wśród humanistów członków kapituły oznak osłabienia ortodoksyjnej wiary, czy też objawów wątpliwości i wahań. $\mathrm{Na}$ pierwszy plan wysuwa się postać Jana Łaskiego, prepozyta gnieźnień- 
skiego, który w tym czasie, kiedy Hozjusz wchodził do kapituły, tj. w r. 1540, pożegnał się z Kościołem. Komedia z rzekomym nawróceniem w r. 1541 nie miała nic wspólnego z rzeczywistą konwersją. Niepokój reformacyjny wykazywali także Jakub Uchański, przyszły prymas (1562-1581), Jan Drohojowski, przyszły biskup kujawski (1551-1557), Jan Drzewicki, Stanisław Wolski i Maciej Bal.

Powszechną wadą charakteryzującą przeważną ilość członków ówczesnych kapituł, zwłaszcza przedniejszych katedr, do których dostęp był zastrzeżony ( $\mathrm{z}$ wyjątkiem quinarius numerus plebeorum doctorum) dla potomków kilku pokoleń liczącej szlachty, była chciwość klerykalna, to jest zbieranie $\mathrm{w}$ jednym ręku i w jednym czasie wielu beneficjów kościelnych; kumulacja ich nieraz w wielkiej ilości miała na celu umożliwienie kościelnym prałatom życia na magnackim poziomie. Nie uważali tego za rzecz zdrożną, bo te bona spiritualia były nadawane im powagą Kościoła, co w pewnej mierze rozgrzeszało ich od zarzutu nieumiarkowania $\mathrm{w}$ gromadzeniu dóbr doczesnych. Walka o beneficja prowadziła nieraz do ciężkich sporów, awantur, sprzeczek, procesów sądowych i odwołań do Rzymu. Przykładem tego może być zachowanie się Jana Naropińskiego, który za miejsce proklamacji swych pretensji w sprawie prebendy prałackiej w kapitule obrał katedrę krakowską i napełniał krzykiem jej przestrzeń sakralną. Sam Hozjusz naraził się na ostry spór z Jakubem Uchańskim w sprawie dziesięcin z pól bieżanowskich.

Mimo ogromnych dochodów, jakie dawały skumulowane majątki kościelne, korzystający z nich członkowie kapituły nieraz cierpieli na brak pieniędzy i umierając często byli pogrążeni w długach. Utracjuszami lekkomyślnie wyrzucającymi grosz kościelny w kapitule krakowskiej byli: Benedykt Izdbieński, Andrzej Zebrzydowski, Jan Konarski, Jerzy Podlodowski, Hieronim Rosborski, Wilhelm Jarocki i Stanisław Przeborowski, mieszkający naprzeciw kościoła św. Marii Magdaleny (ul. Kanonicza 9), który był przy końcu życia takim bankrutem, że po śmierci został pochowany na koszt kapituły i biskupa Samuela Maciejowskiego. Ta sytuacja i nawyki duchowieństwa polskiego tłumaczą nam, dlaczego Kościół polski zasadniczo nie respektował uchwały Soboru Trydenckiego o zakazie kumulacji beneficjów i starał się różnymi sposobami zakaz ten obchodzić. Jeszcze po soborze pojawiają się zjawiska „proboszczów całej Polski”, czy „kochanków 11 tysięcy dziewic”.

Jak to widzieliśmy $\mathrm{w}$ poprzednim rozdziale, również i Hozjusz godził się na kumulację wielu swoich uposażeń kościelnych, łączenie bowiem beneficjów w rękach jednego posiadacza tak było wówczas zakorzenione $\mathrm{w}$ zwyczajach polskiego duchowieństwa, że kto by się temu sprzeciwiał, mógłby być podejrzany o brak ducha kościelnego. Na usprawiedliwienie jednak Hozjusza możemy podać, że nasz doktor nigdy się 37 - Analecta Cracoviensia 
nie ubiegał się o dodatkowe beneficja, lecz one same do niego przychodziły. Mamy dowody źródłowe, że opierał się przyjęciu plebanii w Gołębiu i że narzucona mu została kanonia sandomierska. Gdy zaszła potrzeba chętnie $\mathrm{z}$ beneficjów rezygnował, jak o tym wzmiankowano w poprzednim rozdziale. Nigdy nie prowadził żadnego sporu przy obejmowaniu beneficjum. Poza tym Hozjusz obracał dochody wpływające z beneficjów na korzyść tych majątków, z których je otrzymywał, a więc na remont kamienic, w których mieszkał, zachowywał w świetnym stanie gospodarstwa rolne oraz budynki gospodarcze. Z tego powodu spotykał się bardzo często $\mathrm{z}$ pochwałą kapituły, miewającej przecież w większości wypadków niemałe kłopoty z lekkomyślnym niszczeniem przez beneficjatów swej substancji majątkowej. Otrzymane pieniądze ze źródeł kościelnych obracał Hozjusz na prace naukowe, na zakup i wydawanie książek oraz na cele publiczne. Wszelkie podróże związane ze służbą dworowi królewskiemu opłacał z własnej kieszeni. Jadąc w r. 1549 na prośbę Zygmunta Augusta w poselstwie do króla Ferdynanda i cesarza Karola V, sam pokrywał koszta tej podróży, która trwała długie miesiące, bo w kasie królewskiej na ten cel brakowało pieniędzy. Wreszcie według świadectwa jego żywotopisarzy - Hozjusz dużo wydawał na cele miłosierdzia chrześcijańskiego. Wprawdzie w aktach kapitulnych nie znajdujemy o tym żadnej wzmianki, ale ten brak zapisów można tym tłumaczyć, że kapituła nie zajmowała się prywatnymi wydatkami swoich członków.

Na Hozjuszu również nie ciąży plama wyzysku i ucisku poddanych, co nieraz zdarzało się $\mathrm{w}$ majątkach nawet wzorowych skądinąd prałatów. Zamożność Hozjusza oparta była na sprawiedliwym traktowaniu pracowników rolnych, wykonywaniu należytej opieki nad nimi ku zadowoleniu poddanych, rządzeniu się słusznością a unikaniu oznak chciwości i okazywaniu raczej aktów miłosierdzia.

Beneficja kanonikalne często brali klerycy posiadający tylko niższe święcenia. Przy instalacji zobowiązywali się wobec kapituły, że w najbliższym czasie przyjmą wyższe święcenia, przynajmniej subdiakonatu, ale częstokroć długo trzeba było na to czekać. Kanonicy nie posiadający wyższych święceń formalnie nie mieli wstępu do kapitularza i nie mieli prawa do pobierania pożytków chórowych, lecz tego surowo nie egzekwowano ${ }^{531}$. Niektórzy kanonicy, a: nawet prałaci kapitulni, może dlatego opóźniali przyjęcie wyższych święceń kapłańskich, żeby jakó minorzyści (posiadający niższe święcenia) nie związani jeszcze przyrzecze-

531 Sprawa przedłożenia świadectwa święceń subdiakonatu (litterae formatae) Macieja Zieleńskiego trwała 7 lat (tamże, k. 300'). Brak święceń kapłańskich u kanoników wpływał na obniżenie życia duchowego wielu członków kapituły i przyczyniał się do ich zeświecczenia. 
niem celibatu, łatwiej mogli porzucić stan duchowny, gdy zapragnęli szukać kariery świeckiej. Za to od niższych kolegiów katedralnych kapituła kategorycznie żądała, żeby każdy ich członek posiadał święcenia kapłańskie i osobiście, a nie przez zastępcę spełniaj przepisane statutem obowiązki mszalne. Członkowie kapituły nie posiadający święceń prezbiteratu spełniali wypadające na nich obowiązki mszalne przez kolegów z kapituły wyświęconych na kapłanów, odnośnie zaś do często przez nich przyjmowanych altarii katedralnych - przez lektorów mszalnych werbowanych spośród gracjalistów, to jest kapłanów nie posiadających beneficjum, lecz żyjących ex gratia, czyli ze stypendiów za usługi duchowne świadczone bractwom i cechom. Tę anomalię usunął Sobór Trydencki, który zabronił dopuszczać do kapituł duchownych bez święceń kapłańskich.

Członkom kapituł polskich, a zwłaszcza stołecznej kapituły krakowskiej, bardzo zależało na tym, aby wejść na wpływowy dwór biskupi, zwłaszcza dlatego, że krakowscy rządcy diecezji zazwyczaj dzierżyli pieczęć kanclerską lub prokanclerską i mieli wielki wpływ na sprawy awansu na najbogatsze prałatury $w$ Polsce i na biskupstwa. Hozjusz nigdy nie ubiegał się o zaszczyt domownika biskupiego, raczej sami biskupi wzywali go do siebie, czy to Piotr Tomicki do „Domu Ciołka” (,domus Ciolkonis", ul. Kanonicza 17), czy Jan Chojeński do kurii przy ul. Poselskiej 12, albo Piotr Gamrat na powrót na ul. Kanoniczą 17, wreszcie Samuel Maciejowski do kamienicy „św. Grzegorza” (ul. Kanonicza 1). Prałatom i kanonikom szczyczącym się klejnotem szlacheckim bardzo też chodziło o awans na dworze królewskim, skąd łatwo było sięgnąć po biskupstwo. Hozjusz o tym nie myślał, chętnie jednak przyjął wezwanie na sekretarza królewskiego i na tym stanowisku dobrze przysłużył się ojczyźnie, bez jakichkolwiek widoków na godność biskupią, bo mu drogę do niej zagradzało plebejskie (mieszczańskie) pochodzenie. Królewska nominacja Hozjusza na biskupstwa pruskie, na które nie było wymagane pochodzenie szlacheckie, dokonana była ze strony Zygmunta Augusta motu proprio w uznaniu dla jego zdolności i pracy dla polskiej ojczyzny, a także w przewidywaniu dużych korzyści z tej nominacji dla Kościoła i Państwa na północnych kresach Polski. Hozjusz bowiem całe swe życie traktował jako służbę społeczeństwu, polskiemu narodowi i ukochanej instytucji Kościoła Chrystusowego.

Wyjeżdżając z Krakowa w r. 1550 jako 45-letni sługa Kościoła, niósł ze sobą w dalsze życie bogaty zasób doświadczenie zdobytego na dworze królewskim, znajomość spraw Kościoła osiągniętą przy boku czterech wybitnych biskupów krakowskich, doskonałe rozeznanie życia duchowieństwa różnych szczebli, jego zalet i złych stron, przekonanie a potrzebie reformy Kościoła w urządzeniach prawnych i życiu całej spo- 
łeczności kościelnej, a przede wszystkim zabierał ze sobą uformowane w Krakowie wielkie bogactwo nauki teologicznej i jej problemów, co doskonale wykorzystał $\mathrm{w}$ napisanej w niedługim czasie swej Konfesji. I przy tej postaci możemy zawołać: „Felix Cracovia”!

\title{
STANISLAW HOZJUSZ AU CHAPITRE CRACOVIEN (1540-1550)
}

\author{
Rés u mé
}

Un des plus grands hommes de l'Eglise polonaise, Stanislaw Hozjusz, né à Cracovie, a passé presque 30 années de sa vie dans sa ville natale; les dix demières années avant de recevoir le sacre épiscopali il appartenait au chapitre cracovien qui comptait alors 36 membres.

Il est entré au chapitre en 1540 et s'est retrouvé parmi des hommes qu'il connaissait bien, non seulement parce qu'il était un religieux cracovien, mais aussi à cause des 20 ans passés à la cour des évêques cracoviens (de J. Konarski, de P. Tomicki, de J. Chojenski, et de P. Gamrat) et que depuis 1538 il avait été le secrétaire du roi. Le chapitre était composé pour la plupart de courtisans et d'évêques. Hozjusz y a trouvé des amis sincéres aussi des esprits méfiants qui se tenaient loin de lui: avant tout les chanoines qui n'étaient pas à la hauteur de leur vocation sacerdotale. En vivant dans la communauté du chapitre, ile a été témoin de différentes formes de la vie commune des frères capitulaires. On y voyait des exemples de bienveillance cordiale, mais aussi des lacunes évidentes dans le comportement envers les autres. Hozjusz s'intéressait plus particulièrement à l'attitude de ses confrères envers la foi catholique, surtout face à la propagande des autres croyances et schismes qui menaçaient le dogme de l'Eglise. Avec un groupe de chanoines, Hozjusz était un des gardiens fidèles l'orthodoxie chrétienne. A plusieurs reprises, par ordre de l'évêque et par décision du chapître, il a prit part à l'activité inquisitoire, y compris contre l'ensemble de la congrégation de son propre chapitre.

L'application des règles de la morale chrétienne et les tentatives d'approche de l'idéal de sainteté de la vie sacerdotale par ses confrères préoccupaient Hozjusz. Dans ce domaine aussi les religieux catholiques subissaient la menace non seulement des principes dictés par la réforme erronnée de l'Eglise, venant de I'Ouest, mais plus encore du relâchement des moeurs dans le milieu des humanistes italiens, dont le genre de vie influençait les membres présents et futurs du chapître qui pendant leur jeunesse étudiaient en Italie. Hozjusz remplissait assidûment les devoirs qui lui incombraient en sa qualité de chanoine: il servait le chapitre par son savoir théologique et juridique. Choisi, à plusieurs reprises pour être commissaire ou délégué, il a toujours bien rempli sa tâche. Ajoutons les obligations liées à la charge d'administrateur des biens et des maisons capitulaires, les prébendes qu'il récévait en tant que chanoine. Il les gérait parfaitement et le chapitre l'en a souvent félicité. L'image générale du chapitre cracovien, dans lequel Hozjusz a travaillé entre 1540 et 1550, avant de partir, en tant que légat diplomatique chez Habsbourgeois et avant d'être nommé à l'évêché de Chełmno, est plutôt positive. Malgré quelques ombres, le chapitre cracovien a été en pra- 
tique dévoué à la foi catholique et à quelques exceptions près, il chérissait les devoirs de la vie sacerdotale.

La présence de Stanisław Hozjusz a certainement eue une influence positive sur le comportement des membres du chapitre, L'exemple, incontestablement imposant, de sa foi et de sagesse, ainsi que celui de sa vie sans tâche ne pouvaient laisser son entourage indifférent. 